\title{
Establishing a Global Network
}

In mid-August 1924, the revolutionary transport workers summoned for their fourth conference in Hamburg. A few months earlier in Moscow, the Comintern had held its Fifth World Congress followed by the Third World Congress of the RILU in June/July 1924. Trade union tactics ranged high on the agenda of both congresses. The split of the labour union movement was evident for all, and voices were raised that communists should either join or form revolutionary unions. Still, the leaders of the Comintern and RILU stood firm behind their calls for trade union unity and issued a resolution denouncing the social democrats and socialists (i.e., "reformists") as splitters. The Comintern Congress branded the leaders of the unions and the Amsterdam International, i.e., the IFTU, as supporters of conservative, backward, national narrow-minded and bourgeois-imperialist sentiments. The communists, in turn, were to remain within the existing unions, and the Comintern ordered them to endorse the 'United front from below'-tactics. Their core task was the extension of communist influence within the unions and, ultimately, to assume control of the union leadership. ${ }^{1}$ Communist trade union strategies and tactics dominated discussions at the RILU Congress. The Congress urged its members to stick to the RILU programme and tactics. Echoing the Comintern theses on tactics in the trade unions, communist ideas were to be promoted among the rank and file of the unions and to push for a 'united front'. The communist vision of a unified trade union movement was to be achieved at a projected World Unity Congress of the RILU and the IFTU. ${ }^{2}$

The Comintern and RILU declarations on the 'United front from below' were made in the aftermath of the failed hopes for a 'Unity Congress' of transport workers in autumn 1923. The ITF General Council rejected the idea, and the ITF cemented its negative stance towards admitting communist-controlled unions within its ranks at its congress, summoned in Hamburg 7 to 12 August

1 Fifth Congress of the Communist International, Theses on tactics in the trade unions (1924), first published in Inprecor 4, no. 119 (16 September 1924): 1577; also available at https://www. marxists.org/history/international/comintern/5th-congress/trade-unions.htm.

2 A. Lozovsky, "The Results of the III. Congress of the R.I.L.U," Inprecor 4, no. 56 (7 August 1924): 506-507; "For the Unity of the Trade Union Movement," Inprecor 4, no. 66 (18 September 1924): $718-719$. 
1924. ${ }^{3}$ RILU General Secretary Lozovsky condemned the ITF decision, and announced that the RILU had revoked its decision to dissolve the International Propaganda Committees. ${ }^{4}$ The IPC-TW, in turn, denounced the ITF Hamburg Congress for sabotaging the international unity of the transport workers' movement as the representatives of the revolutionary opposition had been silenced at the congress and the Russian Railway and Transport Union had not even been invited to attend the congress. ${ }^{5}$

The revolutionary transport workers organised their own conference from 12 to 15 August 1924 just after the closure of the ITF Congress. ${ }^{6}$ Some of delegates (most likely) had participated at the ITF Congress, others not, as the delegates represented opposition groups within legal and illegal trade unions of land and maritime transport workers in Britain, China, Czechoslovakia, Finland, France, Germany, Italy, Java, the Netherlands and Spain. ${ }^{7}$ Interestingly, there was no representative or delegation from the Russian transport workers' union. On the other hand, this comes as no surprise as the IPC-TW was neither obliged nor ordered to conduct agitation and propaganda in Soviet Russia.

The composition of the delegations attending the 1924 Hamburg Conference gives a hint about the expansion and areas of activity of the IPC-TW. In contrast to the predominantly European extension of the ITF, which included member unions in Austria, Argentina, Belgium, Britain, Denmark, Czechoslovakia, Finland, France, Germany, Greece, Italy, Latvia, Luxembourg, the Netherlands, Norway, Palestine, Romania, Spain, Sweden, Switzerland and the USA, ${ }^{8}$ the IPC-TW had only connections to minorities and revolutionary groups within the European transport workers' unions. Soviet Russian trade unions as well as revolutionary or red trade unions in Europe, including the Schiffahrtsbund,

3 See further Report on the International Congress held from 7 to 12 August 1924 in the Large Hall of the Gewerkschaftshaus Besenbinderhof Hamburg (Amsterdam: International Transport Workers' Federation, 1924).

4 A. Lozovsky, "The Struggle for the Unity of the International Trade Union Movement," Inprecor 4, no. 6o (21 August 1924): 634 .

5 P.B., "The Hamburg Conference of the Transport Workers' Federation," Inprecor 4, no. 63 (4 September 1924): 62-63.

6 Similar to its earlier meetings, the IPC-TW published a report and resolutions of the conference in the Internationales Transportarbeiter-Bulletin. Unfortunately, I was not able to consult the publication.

7 [Achkanov,] "Vorwort," in Die 5. Internationale Konferenz der Revolutionären Transportarbeiter Abgehalten in Moskau im April 1928 (Moskau: Internationales Propagandaund Aktionskommittee der revolutionären Transportarbeiter, 1928), 5. [Hereafter: Die 5. Internationale Konferenz der Revolutionären Transportarbeiter.].

8 See list of ITF member unions in Report on the International Congress held from 7 to 12 August 1924 . 
were members of the RILU, not the ITF. Nevertheless, the main difference to the ITF were the connections to Asian transport workers' unions and associations, among others in China and in the Dutch East Indies (Indonesia). Most notably, the IPC-TW rather than the ITF had the ambition to reach out to nonEuropean/non-Western/non-white unions and aspired to evolve as a global player. $^{9}$

Four years later, the global outreach of the IPC-TW was manifested at its fifth conference that convened in Moscow in early April 1928. IPC-TW Secretary Grigorii (Gregory) Pavlovich Achkanov (1887-1937) boasted that the IPC-TW was active in 43 countries all over the world and that the revolutionary minorities within the unions counted about two million members. Achkanov himself had started as IPC-TW Secretary in 1926. He was a high-profiled Russian Bolshevik and had already participated in the Revolution of 1905, being then a mariner and one of the instigators of the uprising in Odessa. From 1921 to 1923, he was, among others, a member of the Collegium of the People's Commissariat of Transportation of the USSR, vice-chair of the Central Committee of the United Transportation and Water Transport Workers' Union (Tsektran), and a member of the Presidium of the All-Union Central Council of Trade Unions (VTsSPS). ${ }^{10}$

The geographical spread of the delegations attending the 1928 Moscow Conference was impressive and included participants from the Antilles, Argentina, Australia, Britain, Bulgaria, Canada, China, Cuba, Czechoslovakia, Denmark, Ecuador, France, Germany, Greece, India, Indonesia, Italy, Japan, Korea, Mexico, the Netherlands, Norway, Peru, Poland, Portugal, Romania, Switzerland, Turkey, Uruguay, the USA and Yugoslavia. ${ }^{11}$ Besides oral propaganda, conducted at meetings of revolutionary unions and in the Interclubs, the IPC-TW made extensively use of written propaganda by publishing 17 periodicals in 13 languages, including Arabian, Chinese, Danish, English, Flemish, French, German, Italian, Japanese, Norwegian, Russian, Spanish,

$9 \quad$ Spearheaded by its secretary general Edo Fimmen, the ITF evolved as a global player during the 1930s. See Willi Buschak, Edo Fimmen: Der schöne Traum von Europa und die Globalisierung (Essen: Klartext Verlag, 2002).

10 See further "Achkanov Brothers," The Great Soviet Encyclopedia, 3rd edition (1970-1979), Achkanov Brothers | Article about Achkanov Brothers by The Free Dictionary. The Great Soviet Encyclopedia claims that Achkanov died in 1939. This information is corrected in the 'Open list of victims of political repression in the USSR', which states that Achkanov was executed on 3 December 1937, see https://ru.openlist.wiki/Ачканов_Григорий_ Павлович_(1887).

"Vorwort," in Die 5. Internationale Konferenz der Revolutionären Transportarbeiter, 5-6. 
and Swedish as well as planned to commence publication in Bulgarian and 'Yugoslavian.'. 12

The 1928 Moscow Conference lasted for three days and had mustered 71 delegates representing 37 countries. ${ }^{13}$ At his speech at the opening event, Achkanov hailed the global expansion of activities. He claimed that more workers than ever were supporting the RILU call for a 'united front from below' and the onslaught against the trade union leaders was greater than ever. Local activists had established new Port Bureaus in Copenhagen, Marseille and New York, and together with the existing ones in the Soviet Russian ports, Hamburg, Rotterdam and Bordeaux, had been able to radicalise maritime transport workers. On the other hand, there had been setbacks, he admitted. Fascism was making headway and in some countries, such as Bulgaria and Greece, the authorities had crushed the communist-dominated railway and seamen unions and put them under the control of the 'fascists'. The situation was similar outside Europe: A mixture of progress and defeats. A promising start had been curtailed in China, repressive anti-communist politics prevailed in Japan and Korea, a communist uprising had been crushed in Dutch East India and news from South and North America was disappointing. ${ }^{14}$

The global turn of the Comintern had been initiated at the 1920 Baku Conference and generated during the following years a heated debate about strategies and tactics as well as on focus and outreach. ${ }^{15}$ At first, the 'global' was equivalent to 'the East' in communist vocabulary and publications as well as in the organisational framework of the Comintern and its central unit for 'global' operation, the Eastern Secretariat. The latter was the 'oriental' node at

12 Theses of Report on Activities of IPCAA of Transport Workers, Report by Comrade Achkanov, presented at meeting of the Executive Bureau of the RILU, 8.1.1929, 534/5/207, 16, RGASPI.

13 The composition of the delegations is not known, as I have not been able to trace the list of participants.

14 "Eröffnungsrede von Kamerat Atschkanow," in Die 5. Internationale Konferenz der Revolutionären Transportarbeiter, $7-8$.

15 For a discussion on the Baku Conference and its repercussions in Asia, see Carolien Stolte, "Uniting the Oppressed peoples of the East: Revolutionary Internationalism in an Asian Inflection," in The Internationalist Moment: South Asia, Worlds, and World Views 1917-39, eds. Ali Raza, Franziska Roy and Benjamin Zachariah (New Delhi: Sage Publications India, 2015), 56-85. 
the Comintern headquarters in Moscow and produced the strategic outline for work in China, Japan, Korea, Mongolia, and Turkey as well as the British, Dutch and French colonies in Asia and Africa. ${ }^{16}$ In late January/early February 1922, the Congress of the Toilers of the Far East convened in Petrograd, setting the stage for work in the 'East.' ${ }^{17}$ In November 1922, the RILU adopted the Comintern's theses on colonial work at its second world congress. As its member organisations as well as the International Propaganda Committees were slow in adapting to the new course, the RILU General Council published a stiff reminder on work in Asia in October 1923. Harsh critique was directed towards the revolutionary minorities within the unions in countries possessing colonies, namely Great Britain, Belgium, France, Italy, Japan, the Netherlands, and the USA, reprimanding them for having failed to erect special organs in the colonial metropoles to keep up communications with the labour unions in the colonies. The American, British, French, and Dutch sections were ordered to correct their negative attitude and establish such units within the next three months. At meetings and special gatherings as well as in their publications and press, the sections were instructed to infuse an understanding and a sympathetic sentiment towards the plights of the exploited masses in the colonial and semi-colonial countries. The binding objective of the communist fraction and revolutionary minorities in the trade unions was to fight alongside the proletariat of the colonies; the guiding principle being 'equal pay for equal work', irrespective of nationality, sex or colour of ones' skin. ${ }^{18}$

The RILU General Council further projected a spatial division of anti-colonial work to enhance the politicisation and radicalisation of the workers in the colonial and semi-colonial countries. Here, the colonial maritime transport workers played a crucial role. The British section of the RILU, i.e. the Minority Movement, was to concentrate on the 'Lascars' or Indian seamen as they were identified as an effective means of supporting the revolutionary labour movement in India. The French section of the RILU, especially the communist-dominated Confédération générale du travail unitaire or CGTU, was instructed to work in the French African colonies as well as in Indo-China; the American section, i.e.,

16 A blueprint outlining the anti-colonial and anti-imperialist objectives in Africa and Asia was forwarded by the Eastern Secretariat to the Executive Committee of the Comintern (ECCI) in 1925, see Bericht der Ost-Abteilung [1925], 495/154/238, RGASPI.

17 See further Alliance of Adversaries. The Congress of the Toilers of the Far East, ed. John Sexton (Leiden \& Boston: Brill, 2019). The edition contains the minutes and documents of the congress.

18 Resolution für die Arbeit im Fernen und Nahen Osten an den Generalrat der Profintern [n.d., ca 1923], 534/2/11, 7-9, RGASPI; published as "Resolution on the Work in the Far and Near East," Inprecor 3, no. 65 (6 October 1923): 724-725. 
the Trade Union Educational League, was to focus on the Philippines, the Dutch section on Indonesia, the Spanish section on Tangier, whereas the Greece section was charged to establish connections with unions in Egypt. ${ }^{19}$

However, the RILU General Council did not publish any specific instructions on colonial work by the International Propaganda Committees in conjunction with work among non-white maritime transport workers. These had to wait for the next step of the RILU's move towards the 'East' when Moscow started to address the revolutionary potential of existing of labour unions and associations in the Western Pacific Rim. Especially in China, where the radical Guomindang (Kuomintang) movement or Chinese Nationalist Party had started to cooperate with the communists, ${ }^{20}$ the ground looked fertile to intervene in national seamen's and railwaymen's unions. In January 1922, the Chinese Seamen's Union organised a strike in Hong Kong, which was joined by other transport workers. By early March, some 120,000 workers were involved in the strike, closing much of the city. The communists in Guangzhou (Kanton) and Hong Kong supported the strike but did not lead it. The British colonial government, in turn, intervened to crush the strikers and banned the Chinese Seamen's Union in Hong Kong. Despite the harsh measures, the colonial government agreed to negotiate and the strike was called off after an agreement on wage increases. Commenting the strike and its outcome, Comintern analysts demanded the Chinese Communist Party to closely cooperate with the Chinese Seamen's Union. ${ }^{21}$

\subsection{A World Port to and a Global Port in the Pacific: Vladivostok and Shanghai}

Port cities were central operational nodes for the Comintern and RILU in their ambition to connect with national parties, revolutionary groups and trade union minorities outside Soviet Russia. Two main transnational routes of communication emerged during the 1920s, one Western and one Eastern. Soviet ports were the gateway to and from 'Fatherland of the revolutionary working-class'. The

19 Resolution für die Arbeit im Fernen und Nahen Osten an den Generalrat der Profintern [n.d., ca 1923], 534/2/11, 7-9, RGASPI. The clause on connections to Egypt is missing in the published version.

20 The Communist Party of China (CPC) had been founded in Shanghai in June 1921. The communists dominated the left-wing of the Guomindang. In 1923, the Guomindang and its government in Guangzhou accepted aid from Soviet Russia, paving the way of the establishment of a 'united front' between the CPC and the Guomindang. See further Hans J. van de Ven, From Friend to Comrade: The founding of the Chinese Communist Party, 19201927 (Berkeley and Los Angeles: University of California Press, 1991).

21 Michael Share, "Clash of Worlds: The Comintern, British Hong Kong and Chinese Nationalism, 1921-1927," Europe-Asia Studies 57, no. 4 (2005): 6o7-6o8. 
harbour area in the Soviet ports was a space controlled by the state and party apparatuses and was infused by communist ideology. Soviet ports they were not closed territories but were visited by foreign vessels who called at the ports, mariners disembarked while the ships were staying in port, at best interacting with local maritime functionaries but always under controlled conditions. Sometimes, the crew returned to their ships unimpressed and unaffected of the Bolshevik propaganda although generally, the functionaries of a local Port Bureau were successful in their mission and managed to convince at least some crew members to join the revolutionary opposition of a national maritime trade union.

Soviet ports opened potential routes for Comintern and RILU networks of communication and transfer. Those in the European part of Russia facilitated various possibilities to connect with the 'West' and the Atlantic - through Petrograd/Leningrad via the Baltic, the Black sea ports to the Mediterranean and beyond, and Archangelsk and Murmansk to the northern Atlantic. However, there was only one port serving as the gateway to the 'East' and the Pacific, namely Vladivostok. Together with Shanghai, these two ports emerged as nodes of the "Eastern route'22 through which the Comintern and, by extension, the RILU and IPC-TW, connected with communists and revolutionary opposition groups and trade union minorities in the Western Pacific.

Vladivostok was the eastern terminus of the Trans-Siberian railway and the naval base of the Russian Pacific fleet until the Civil War. (The city resumed to be a naval base in 1932.) Its commercial harbour started operations in 1871, telegraph connections to Shanghai and Nagasaki opened in the same year. In 1916, the trans-Siberian railway connected Vladivostok with Moscow. During the Russian Civil War, a multinational intervention force controlled the town. During this period, the population of the town increased from 97,000 to 410,000 , most of them refugees. Japanese forces stayed until October 1922 when the Red Army took over the control of the town and port; most of the refugees evacuated, too, and by 1926, its population had declined to 108,ooo. The Bolshevik control of Vladivostok paved the way for the IPC-TW to start its work in the 'East'. In January 1923, local functionaries opened a Port Bureau and Interclub at 52 , Ulitza Lenina, serving as the 'gateway to the Pacific'. ${ }^{23}$

The main propaganda tools of the Vladivostok Port Bureau were its Chinese, English and Japanese bulletins as well as its periodical publications in Chinese

22 Akito Yamanouchi, "The Early Comintern in Amsterdam, New York and Mexico City," Kyushu University Institutional Repository [2009?]: 100.

23 Josephine Fowler, "From East to West and West to East: Ties of Solidarity in the Pan-Pacific Revolutionary Trade Union Movement, 1923-1934," International Labor and Working-Class History 66 (Fall 2004): 102; Fowler, Japanese and Chinese Immigrant Activists, 105. 
and Japanese. ${ }^{24}$ The Vladivostok Interclub aimed actively to engage with Dutch, English, German, and Norwegian mariners although its prime target group were Chinese and Japanese seamen. Key objective was to establish direct links to the seamen's unions to enable a "regular exchange of views, opinions and experiences and mutual information about seamen's conditions in the countries of the Pacific." The Interclub therefore sent letters to the opposition groups, among others in Japan, to inquire about "by which means and where to we have to address our correspondence (information, letters, literature)."25

The lack of functionaries fluent in Japanese and Chinese severely hampered work of the Vladivostok Port Bureau. Initially, the bureau's staff comprised only Western, non-Russian functionaries and a Japanese comrade, although the engagement of the latter was restricted to editing the Japanese bulletin. ${ }^{26}$ Responding to the plea from Vladivostok, the Interclub was staffed with a Japanese instructor who, among others, managed to interact with Japanese fishers. Communications with Chinese seamen also prospered, and the Port Bureau sent an instructor to Shanghai in 1925 in order to establish connections between the two ports. ${ }^{27}$

Nevertheless, conditions for agitation and propaganda work were never optimal in Vladivostok. An evaluation of the Interclub, conducted in 1927, depicted its premises as well as its operations as pitiful if not pathetic. The Interclub composed of two small rooms, one occupying the office, the other serving as a meeting room. The meeting room could not seat more than 20 persons altogether. "I cannot see how real work can be done under these conditions," the investigator critically remarked, and noted that the lack of space hindered the Interclub to arrange meetings for foreign seamen. Besides, the Interclub was located on a far distance from the harbour area and was difficult to find. The investigator's conclusions were harsh: "In a big and important port like Vladivostok, a decent club should be established because this port is the connecting link between East and West." In order to meet its political objective, the Port Bureau needed "a place where Eastern and Western nationalities can be worked separately." 28

24 Atschkanow, Bericht des I.P.K.T. über die Hafenbüros, 1.12.1926, 534/5/178, 65, RGASPI.

25 Secretary/International Seamen's Club Vladivostok to "Dear Japanese Comrades," no date [ca. May/June 1923], 495/154/191, 6-7, RGASPI.

26 Minutes of Meeting of Port Bureau July 27, 1923 and August 5, 1923, 495/154/191, 11, 14, RGASPI; Fowler, "From East to West," 103.

27 Atschkanow, Bericht des I.P.K.T. über die Hafenbüros, 1.12.1926, 534/5/178, 65-66, RGASPI.

28 NN to Achkanov, Conficential Report [handwritten], [Vladivostok] 25.3.1927, 534/5/187, 103, RGASPI. The author of the report was most likely the same person who had been sent 
Shanghai stands out as (relatively) open space in contrast to the controlled one in Vladivostok. While the Russian port was of regional importance, Shanghai evolved into a modern industrialised and commercial global centre during the 1920s and 1930s. Shanghai ranked among the largest cities in the world with some 3 million inhabitants, predominantly Chinese, located at the intersection of multiple local, regional, national and global transport networks, not least via its harbour. The city was a multicultural and cosmopolitan metropolis composed of three sections with separated administration and police, the Chinese municipality, the French Concession and the International settlement. The two latter ones were extra-territorial areas with protected status and inhabited more than 50,0oo people of European and Japanese descent, many of the former being Russian refugees who had settled in Shanghai after 1918. The availability of legal protection as well as the existence of modern communication systems and a large international community made Shanghai the ideal node for the Comintern and RILU legal and underground activities in China and beyond. ${ }^{29}$

Shanghai was the ideal place to work for foreign and local communists, as Onimaru Takeshi has demonstrated. There was no restriction on movements between the three sections of Shanghai, leading to what Takeshi defines as "a grey zone within and between these divisions." According to him, "a grey zone was a place where certain degree of ambiguity existed in law enforcement and administrative control." This was the case in Shanghai with its division of police and legal territories in combination with the freedom of passage between the sections. Not surprisingly, Shanghai developed into a major hub for political activism and communist organisations. ${ }^{30}$

Work among foreign seamen seemed to have started in Shanghai in 1925 as an outcome of 1924 Conference of the Transport Workers of the Orient, see

to Shanghai as staff member of the RILU bureau, namely comrade Schwanke. In one of his letters from Shanghai, Schwanke complained about the bad quality of the forged visa and passport that he had received in Moscow. Other reports from Shanghai indicate that the bureau in Shanghai composed of Schwanke, Alex, Grisha and Nadja in 1927, see 534/ 5/193, RGASPI. At least Alex - or another person using the same pseudonym, perhaps one Nick Alexander (although this name could also be an alias) - figured as head of the (re-established) Hamburg Port Bureau in 1924, see 534/5/164, 24, RGASPI, and 534/5/172, 3, RGASPI. Documentation seems to indicate that Alex and Schwanke were running a bureau concentrating on work among foreign seamen in Shanghai but this needs further investigation.

29 Onimaru Takeshi, "Shanghai Connection: The Construction and Collapse of the Comintern Network in East and Southeast Asia," Southeast Asian Studies 5, no. 1 (April 2016): 118-121.

Takeshi, "Shanghai Connection," 120. 
below Chapter 2.1.2. Operations in the harbour area were initially organised by one A. Lindner who seemed to have acted as the local organiser of the RILU and/or IPC-TW in Shanghai. At first, working conditions were constrained due to a strike among Chinese seamen that also affected and paralysed the harbour area in the International settlement. In addition to unruly local conditions, a constant lack of funding curbed Lindner's work in Shanghai. Communist agitators were constantly harassed and faced persecution both by the Chinese authorities and by the leadership of the local branch of the Chinese Seamen's Union. Publishing an own periodical was impossible as the branch leadership collaborated with the Shanghai Chamber of Commerce and was not interested in promoting the radical, i.e., communist, fraction of the branch. ${ }^{31}$ Still, Lindner gradually managed to start his operations in the port and, in cooperation with (communist) members of the Chinese Seamen's Union, interacted with foreign crews. German sailors, he lamented in a report, were badly organised, in comparison to the "revolutionary" potentials of Scandinavian and Dutch mariners. ${ }^{32}$

\section{$1.2 \quad$ The 1924 Conference of the Transport Workers of the Orient}

In early 1924, a RILU-report positively noted about the revolutionary mood among transport workers in China, Japan and the Dutch East Indies (Indonesia). ${ }^{33} \mathrm{~A}$ first step of consolidating contacts was taken at a conference organised by the Comintern in Guangzhou (Canton) in the latter part of June 1924, called the Conference of the Transport Workers of the Orient (also known as the Pan-Pacific Labour Conference). Delegates representing Chinese, Philippine and Javanese railway and maritime workers attended the meeting. ${ }^{34}$ A declaration was drafted in Moscow, outlining the anti-colonial and anti-imperial agenda of the Communists and their willingness to cooperate with the "oppressed nations of the East." What they needed, the declaration stressed, was to have their own "people's parties" to defend the interests of the "toiling masses" and to link up with the "revolutionary movement of the world proletariat" in their fight against colonial exploitation. To achieve this end, the "toiling masses of the colonial and semi-colonial countries" were impelled "to make a united front" with the workers in the colonial metropoles in their fight

31 "The Chinese Seamen's Union," Inprecor 6, no. 46 (10 June 1926): 755.

32 A. Lindner, Tätigkeitsbericht über die Propaganda unter den internat. Seeleuten im Shanghaier Port, Shanghai XI. Monat 1925 [November, 1925], 534/5/168, 76-82, RGASPI.

33 Fowler, "From East to West and West to East," 103.

34 G. Voitinsky, "First Conference of Transport Workers of the Pacific," Inprecor 4, no. 65 (11 September 1924): 704-706. 
against imperialism. Addressing the attendants at the conference, "the labouring masses in the colonies in the Pacific must take heed of this phenomena [...] and organise the toiling masses in real militant bodies against imperialism."35

The RILU must have regarded the 1924 Canton Conference as a major success. The conference adopted a resolution that had been prepared in Moscow and declared its commitment to open an office in Guangzhou. The RILU envisioned the Bureau of Transport Workers of the Pacific, also known as the Canton Bureau, as the window of the IPC-TW towards the 'East'. Previously, work among Chinese and Japanese seamen had been restricted to the Port Bureau in Vladivostok. Whereas the Vladivostok Port Bureau had few means to link up with unions and associations outside Soviet Russia, the RILU believed conditions to conduct trans-national and trans-regional work in countries bordering the Pacific and Indian Ocean to be excellent in Guangzhou. To achieve this end, the Canton Bureau was to be composed of members - secretaries - from China, Philippines, Dutch India, British India and Japan. Further, the task of the bureau was to create and monitor a network of Interclubs in Manila, Hong Kong and Batavia (Jakarta); "[t]he clubs may have small libraries[,] arrange lectures and proper entertainment for the visiting sailors." The bureau secretaries, in turn, were requested to edit a bulletin in Chinese and English languages, to translate its essential parts into the respective language of their countries, and to distribute the bulletin among the (maritime) transport workers. ${ }^{36}$

Hopes for establishing a trans-regional office in Guangzhou were shattered a few months later when the local merchants turned against the Guomindang government of Sun Zhongshan (Sun Yat-sen). As the Guomindang had adopted new policies such as "Unite with Russia" and "Accept Communism" in early 1924, the merchants were afraid that Sun Zhongshan might even adopt Communism. In August, when strikes paralysed Guangzhou, the merchants established their own corps and received weapons from the British. Backed by the communists, the Guomindang army eventually managed to quell the uprising in October 1924. At this point, the regional conflict had grown into an international crisis as various imperial governments supported the warlords combatting the Guomindang government. The shipments of armament and ammunition to China, in turn, resulted in the first 'Hands off China!'-campaign orchestrated

35 Outline of the Report on the Labour Movement and the Struggle for Independence of the Colonial Peoples, handwritten add: to the Conf. of Transp. Work. of the Orient, 23.VI.1924, 495/154/233, 27-30, RGASPI.

36 Organization Resolution Passed by the Organization Commission [handwritten add: of the Transport Conf. of Orient], 23.6.1924, 495/154/233, 32, RGASPI. 
by the Comintern and RILU. In November 1924, the IPC-TW followed suit and published a call to expose the transportation of military equipment to China, to boycott and to refuse to load ships carrying arms to China as well as to convene protest meetings against the imperialist intervention in China. ${ }^{37}$

The Canton Bureau was never established, neither were the projected Interclubs in Manila, Hong Kong and Batavia. Still, a window had been opened to the Global South and, as Indian Communist Manabendra Nath Roy would declare at the end of 1924: Europe is not the World. His vision was a global united (radical) working class movement of organised and unorganised workers outside Europe and America, declaring: "Until all the Chinese, Malay, Indian, Arab and Negro workers are organised and the same wages and labourconditions as enjoyed by the White workers are secured for them, the employers will stand on a vantage-ground, because of their ability to draw upon the unlimited reserve of cheap and unorganised labour." 38 The only question was how to achieve the envisioned global unity?

\subsection{The Fate of the Chinese Seamen's Union}

From the perspective of the IPC-TW, connections to the transport workers' unions in East and South-East Asia were of top priority. Closely linked to the strategic interests of Soviet Russia, and in tune with the general push of the Comintern and the RILU towards China, the focus of the IPC-TW was on the Chinese Seamen's Union. Established in 1920 as the National Seamen's Union of China, and reorganised in Hong Kong in 1921, the union had its headquarters in Guangzhou and counted some 2,00o members. ${ }^{39}$

The establishment of direct links to the Chinese Seamen's Union and its communist opposition members proved difficult. Although representatives of the union had participated at the conferences of the IPC-TW in 1922 and 1924, materials and communications from the conferences had never reached China as the delegates had been jailed by [British? - this is still unclear] authorities on their way home and their luggage was confiscated. Another setback was the aborted plan to establish the Canton Bureau, constraining the publication

37 "Appeal of the International Propaganda Committee of the Transport Workers," Inprecor 4, no. 81 (27 November 1924): 81.

38 M.N. Roy, "Europe is not the World," Inprecor 4, no. 90 (31 December 1924): 1045-1046.

39 Gregor Benton and Edmund Terence Gomez, The Chinese in Britain, 18oo-Present:Economy, Transnationalism, Identity (Basingstoke \& New York: Palgrave MacMillan, 2008), 266. On the activities of the Hong Kong Seamen's Union, see Daniel Y. K. Wang, Marxist Intellectuals and the Chinese Labor Movement: A Study of Deng Zhongxia (1894-1933) (Seattle \& London: University of Washington Press, 1997). 
of propaganda material in Chinese. The Chinese delegate at the 1928 Moscow Conference therefore called for a new approach, and suggested that written material was to be published outside China and distributed among Chinese seamen when they called at European ports. ${ }^{40}$ In other words, to focus on agitation among Chinese seamen on foreign vessels as well as to establish or strengthen sections of the Chinese Seamen's Union in ports outside China. This, in turn, was to become a new mission of the Port Bureaus.

Nevertheless, the main link between Moscow and China was the transSiberian overland route. Directives from the Comintern and RILU headquarters reached China, including the call for a 'United front' of all maritime trade unions and associations. The leader of the Chinese Seamen's Union, Lin Wei-min (1887-1927), attended a meeting of the IPC-TW in Moscow in 1924 and joined the CPC. ${ }^{41}$ On 1 May 1925, the All-China Federation of Trade Unions (also: All China Labour Federation or ACLF) was founded with Lin Wei-min serving as chairperson of the First Executive Committee; after its inauguration, the communistcontrolled ACLF joined the RILU. ${ }^{42}$ Thirty days later, British police troops killed Chinese demonstrators in Shanghai. The May 3oth Incident resulted into widespread demonstrations including a strike of Chinese seamen in Shanghai, and Lin Wei-min instigated strikes in both Hong Kong and Guangzhou in support of the Shanghai strikers. The strike in the two southern Chinese ports lasted until 1926, and the seamen proved among the most militant. ${ }^{43}$ Internationally, the Comintern and the RILU called for the reinvigoration of the 'Hands off China'campaign. ${ }^{44}$

40 “Tätigkeitsbericht des IPAK," in Die 5. Internationale Konferenz der Revolutionären Transportarbeiter, 30-31.

41 "Lin Wei-min (Lin Weimin): Spearhead of Workers Movement," http://www.cityofzhuhai. com/2019-07/08/c_386458.htm (checked 23.1.2020).

42 Wang, Marxist Intellectuals, 103.

43 See further Robert James Horrocks, The Guangzhou-Hongkong Strike, 1925-1926, PhD thesis, University of Leeds, 1994; Arif Dirlik, "Narrativizing Revolution: Guangzhou Uprising (11-13 December 1927) in Workers' Perspective," Modern China 23, no. 4 (October 1997): 372-373; Share, "Clash of Worlds."

44 On the 1925-1927 'Hands off China'-campaign, see further Hans Piazza, "The Anti-imperialist League and the Chinese revolution," in The Chinese Revolution in the 1920s: Between triumph and disaster, eds. Mechthild Leutner, Roland Felber, Mikhail L. Titarenko and Alexander M. Grigoriev (London and New York: RoutledgeCurzon, 2002), 166-176; Tom Buchanan, East Wind. China and the British Left 1925-1976 (Oxford: Oxford University Press, 2012); Fredrik Petersson, "We Are Neither Visionaries Nor Utopian Dreamers": Willi Münzenberg, the League against Imperialism, and the Comintern (Lewiston: Queenston Press, 2013), and Kasper Braskén, The International Workers' Relief, Communism, and Transnational Solidarity (London: Palgrave MacMillan, 2015). 
At the height of the strike, the General Congress of the Chinese Seamen's Union convened [in Guangzhou?] at the end of 1925. Expectations at the RILU headquarters must have been high. Union membership had increased to over 30,0oo maritime transport workers. The union had branches in all larger ports in China, the strongest ones being those in Shanghai and Guangzhou. Although conditions in all ports except Guangzhou were difficult, RILU informants assured that the main bulk of the union members supported the revolutionary minority within the union. These, in turn, constituted the majority of the 200 delegates at the Congress. Not surprisingly, the communist agenda triumphed at the Congress. As an outcome, the Congress voted in favour of joining the RILU and for affiliating with the IPC-TW. 45

Moscow hailed the 1925-26 Chinese seamen's strike as a success but disturbing news soon followed. Inspired by the 1924 Canton Conference as well as a reaction to British imperialism in China, the communist fraction within the Australian Trades Union Congress launched the idea to organise the Second Pan-Pacific Trade Union Conference in Sydney under the auspices of the communist-led New South Wales Trades and Labour Council at the end of July $1926 .{ }^{46}$ Moscow supported the idea and issued a call for the conference. ${ }^{47}$ However, the Australian nationalist government dashed the plan of the communists by denying visas for the delegates to enter Australia. The RILU made a new attempt to organise the conference in the following year in conjunction with the May Day celebrations in Guangzhou. Perhaps for the first time, the organisers put "the question of emigration of coloured workers" on top of the agenda and, as Lozovsky highlighted, to direct its attention "to the whole medley of national, racial and religious antagonisms at present prevailing in the Pacific countries." 48

45 "The Chinese Seamen's Union," Inprecor 6, no. 46 (10 June 1926): 755.

46 G.V. Portus, "The Australian Labour Movement and the Pacific," Pacific Affairs 3, no. 10 (1930): 927; Sophie Loy-Wilson, “'Liberating' Asia: Strikes and Protest in Sydney and Shanghai, 1920-39," History Workshop Journal 72, no. 1 (October 2011): 74 - 102.

47 A. Losovski[sic], "The Trade Union Conference of the Countries of the Pacific Ocean," Inprecor 6, no. 41 (13 May 1926): 661-662.

48 A. Lozovsky, "On the way to Trade Union Unity in the Countries of the Pacific," Inprecor 6, no. 7 o (28 October 1926): 1227. Invitations had been sent to the trade unions of China, Japan, Soviet Russia, India, South Africa, Java, the islands in the Pacific, South America, Canada, the USA and the United Kingdom. Apart from the Australian government being negative to idea of a communist conference in Sydney, most of the invited unions declined to come either due to financial constrains or political considerations. See further Farrell, International Socialism and Australian Labour; Frank Farrell, "The pan-Pacific trade union movement and Australian labour, 1921-1932," Australian Historical Studies 
These plans, too, had to be aborted due to the rapidly deteriorating political situation in China. In April 1927, the new Guomindang leader Chiang Kaishek broke with the communists and launched an attack on the communist stronghold in Shanghai. ${ }^{49}$ The British authorities, in turn, crushed the Hong Kong branch of the seamen's union and forced its leaders into exile. ${ }^{50} \mathrm{In}$ tandem with other communist organisations, the IPC-TW protested against the onslaught of the 'imperialists' and called the marine transport workers to block the transportation of war equipment to China, see Figure $3 .{ }^{51} \mathrm{In}$ May 1927, the united front between the Guomindang and the communists had collapsed, and the Guomindang government started to suppress the communist-controlled seamen's union. The Guangzhou branch was closed down; the union's headquarters were moved to Shanghai and were put under Guomindang control. ${ }^{52}$ In December 1927, Guomindang forces brutally quelled a communist uprising in Guangzhou, ${ }^{53}$ triggering a new international communist-orchestrated protest wave. ${ }^{54}$ In the midst of this depressing news, the IPC-TW reported an immense success: the amalgamation of all seamen's unions into one 'unity' union in early 1928.55 In August 1928, its Executive Committee called upon Chinese seamen to "organise your fellow seamen in Europe and America," paving the way for a global network of revolutionary nuclei of Chinese seamen. ${ }^{56}$

Communist trade union activities among Chinese seamen continued through the Port Bureaus in Europe and the European branches of the Chinese Seamen's Union (see Chapter 4.2.2). Inside China, illegal work came under the direction of the Pan-Pacific Trade Union Secretariat or PPTUs. This unit had been established by the RILU during the midst of the crisis in China. Although the All-China Federation of Trade Unions had been destroyed in the aftermath of the Guomindang purge of the communists in Guangzhou, the

17, no. 69 (1977): 441-457; Frank Farrell, International Socialism and Australian Labour (Sydney: Hale and Iremonger, 1981).

49 Dirlik, "Narrativizing Revolution."

50 Share, "Clash of Worlds."

$5^{1} \quad$ "Transport av trope- og krigsmateriel til Kina må hindres," Den internasjonale transportarbeider 2, no. 3 (1927): 3 .

52 Benton and Gomez, The Chinese in Britain, 266.

53 See further Dirlik, "Narrativizing Revolution," 363-397.

54 "Appeal of the E.C.C.I. on the Events in Canton," Inprecorr 7, no. 72 (22 December 1927): 1633 .

55 "Tätigkeitsbericht des IPAK," in Die 5. Internationale Konferenz der Revolutionären Transportarbeiter, 19.

56 Fowler, "From East to West and West to East," 105. 


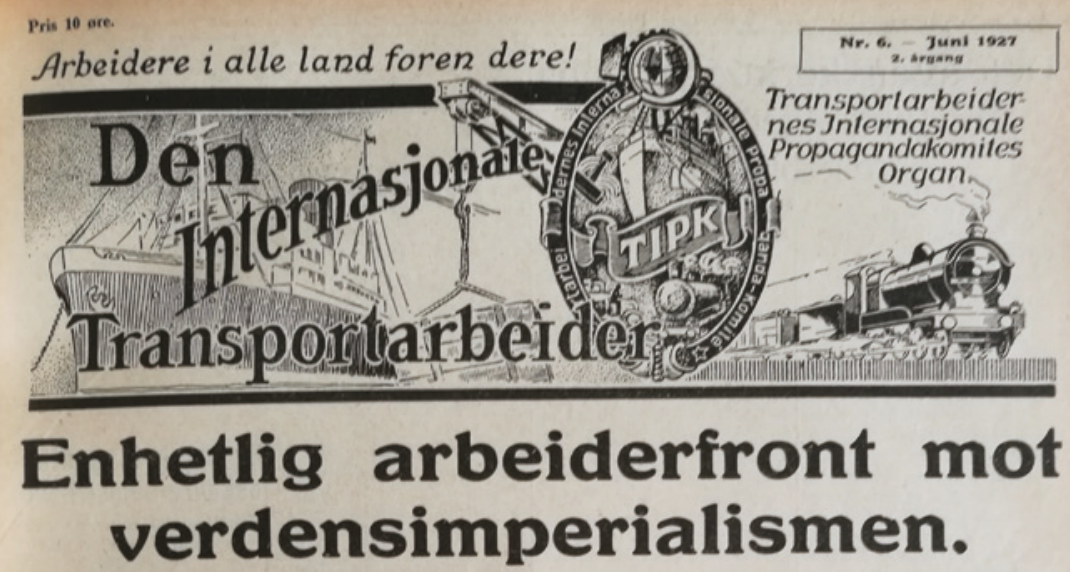

Den engelske Baldwin-regjering har opsagt liandelatraktaten of brutt den diplomatinke forbindelar med Sovjet-Unionen, Hvad betyr sá det? Hvad er folgene? Efter Paidwin-regjeringens utsagn er dette etwerken fred eller krigs. Baldwin erkierer sogar at han delsforbindelsen vil fortsette ufor andret. Dette er en loddrett logen Hensikten er à fore bele verdens arbeiderklasse pá villspor, fore det internasjonale proletariat i stupiditet og hisse det mot verdens forste arbeider- og bonderepublikk. Vi kjenner av tidligere erfaringer
hworiedes den elendige bande som hworiedes den elendige bande som
nu avgjor England og dets koloniers akjebne ikke er ầ stole pî. vi har sett dens logn og bedrag. Det var den samme klikk nom forte arbeiderklassen bak lyset i 1920 . Den samme Churchill som nu sit ter i Baldwins ministerium, erhierte $f$. eks, dengang i 1919 offi-
cielt til hele verden fra parlamen-

Til hele verdens arbei. derklasse. tets talentol at den engelske be elssisterer of vokaer, at den voi garn, ja den europeiske reaksjon i actlelse av Arkangelsk vilde bi $\sin$ blotte eksistens maner hele ver- det hele tatt, holder sig utelukkentrukket tilbake. Men en kjensgjerning er det at det var det mot- kamp og tilintetgiarelec av borger. der

satte som nkjoble, nye militane akapets herredomme. Dens for- Det engelske borgerakap foler styrker blev sendt avghirde mot ar- brytelses er dens sympati for det jorden ryste under sine fotter. Det hr beideritaten. Bare arbeciderpres- internasjonale proletariat som imperium som er sammenrsvet

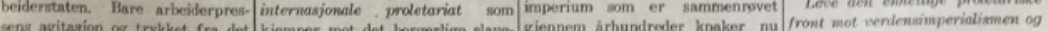

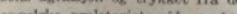
dengang â tvinge det engelake borak; dens dorbrytelses at den ikke i alle sine fuser. Do undertrykte genikap til a opgi intervensjoren. de engelake grubecrbeideres helte herredemmes endelige avalutning Den nuvarende Baldwin-regjering wodlige kasap - men hjalp dem of- normer aig. Men jo mer tingene kunde bare ved hjelp av et forfal- ter beate evner, og tilalutt bigger utvikler sig, desto mere raser Bn.-

FIGURE 3 Towards a united front of the workers against imperialism ("Enhetlig arbeiderfront mot verdensimperialisme"), call published in Den Internasjonale Transportarbeider 3, no. 6 (June 1927), in support of the international 'Hands off China'-campaign.

RILU managed to move the Pan-Pacific Trade Union Conference to Hankou, which was controlled by a local coalition of leftist-Guomindang members and communists. The Pan-Pacific Trade Union Conference convened in May 1927 and was opened by RILU Secretary Lozovsky. The main outcome of the 
conference was the establishment of a permanent secretariat headed by George Hardy to coordinate left-wing trade union work in the Western Pacific as well as to publish its own journal, the Pan-Pacific Worker. Active from October 1927, the secretariat operated at first openly in Hankou but the split between the Guomindang and the CPC forced it underground. The Secretariat was then moved to the foreign-controlled International settlement of Shanghai, where American communist Earl Browder, who replaced Hardy in February 1928, ran its operations. ${ }^{57}$

Shanghai emerged as the communist centre of the East in early 1928. A few years earlier, the Comintern had established its Far Eastern Bureau (FEB) in Shanghai, and, as outlined by Onimaru Takeshi, the Fев and PртUs were in charge of supervising communist parties and labour movements in East and Southeast Asia. The original mission of the FEB was to supervise the communist party organisations in China, Japan and Korea, while the PPTUs focussed on supporting and promoting labour union movements in China, Japan, Korea, India and Southeast Asia. Although formally separate organisations, most of their personnel and activities overlapped. ${ }^{58}$

\subsection{Shattered Hopes:Japan and Indonesia}

Communist agitation and propaganda among Asian transport unions proved much more difficult outside China. Initially, the conditions for organising the working class seemed positive with the establishment of communist parties in the Dutch East Indies (Indonesia) in 1920, the Communist Association of the Indies, renamed as the Communist Party of Indonesia in 1924, and in Japan in 1922. However, an imminent revolution was, according to Comintern analysts, not foreseeable in Japan or in Indonesia.

The Comintern exhibited an ambivalent attitude especially towards Japan. Industrially developed, never colonised, and with a large military force and an

57 Fowler, Japanese and Chinese Immigrant Activists, 76. See also Portus, "The Australian Labour Movement," 928. Farrell, International Socialism; David McKnight, Espionage and the Roots of the Cold War (London: Frank Cass, 2006), esp. chapter 4: The Comintern Underground in Shanghai. The extent to which Hardy effectively operated the PPTUS in China is unclear. According to Special Branch and other information in his dossier, Hardy resided in Moscow at least from April to August 1927, among others writing and publishing articles in the Communist press on the 'Hands off China'-campaign. At least in February 1928, he was believed to be in China. When he returned to England on 20 August 1928 without a passport, he claimed to have lost it in China, see George Hardy personal file KV $2 / 1027$, TNA.

$5^{8}$ Takeshi, "Shanghai Connection". See also Frank Farrell, "Australian Labour and the Profintern," International Review of Social History 24, no. 1 (April 1979): 34-54. 
imperialistic agenda towards Korea and China, Japan was identified as a threat to Soviet Russia. On the other hand, the country had a large agricultural sector and was governed by feudal-imperial institutions, thus depicting it at the same time as a 'semi-feudal' state. The Comintern analysts therefore argued that Japan had to go through the same process as China and India, namely via a bourgeois revolution and a subsequent proletarian revolution. In praxis, this meant that the Japanese communists were to enforce a similar united frontpolicy as in China, namely the formation of a united anti-imperialist front with the bourgeois revolutionaries. The Comintern therefore termed Japan as a "semi-colonial" country and tasked the Japanese communists to engage in the anticolonial struggle against Japanese imperialism. Nevertheless, as Tatiana Linkhoeva demonstrates, Japanese communists refuted the Comintern analysis. Instead, they claimed that the primary task of the Communist Party of Japan (CPJ) was to foment a proletarian revolution that would overthrow the capitalist system at home..$^{59}$

Initial communist activities in Japan ended short. Japanese authorities banned the CPJ one day after it had been set up in 1922. Police arrest of hundred party members in June 1923 severely hampered underground activities. Another blow came in the aftermath of the Great Kanto Earthquake of 1 September 1923 when Japanese working-class mob ignited Japanese army reservists and civilian volunteers to kill several thousand Korean and Chinese residents whom they accused of burning houses, killing people, and stealing money and property. Terrified by these pogroms, the remaining party leadership reconsidered the readiness of the Japanese proletariat for an internationalist socialist revolution, and disbanded the party on 22 October 1923. In March 1924, members of the CPJ, who had managed to escape to Vladivostok and Shanghai, established a bureau in Vladivostok that acted as an intermediary between Moscow and underground communists in Japan. ${ }^{60}$

Meanwhile, Soviet-Japanese relations ameliorated after the establishment of diplomatic relations between the USSR and Japan in January 1925. However, the anti-Japanese strikes in Shanghai (the May Thirtieth Movement) in the same year cooled the Soviet-Japanese rapprochement, and with the known anti-Communist general Tanaka Gi'ichi being appointed prime minister in

59 Tatiana Linkhoeva, "New Revolutionary Agenda: The Interwar Japanese Left on the "Chinese Revolution"," Cross-Currents: East Asian History and Culture Review. E-Journal No. 24 (September 2017), 86-88, http://cross-currents.berkeley.edu/e-journal/issue-24. 
April 1927, Japan's foreign policy turned aggressive. In May 1927, Japan made its first (but not last) military intervention in China. ${ }^{61}$

As Japanese authorities had outlawed the Communist Party, communist activities within the seamen's unions were both illegal and insignificant during the 1920s. In 1921, 23 Japanese seamen's organisations had united and formed the Nippon Kai-in Kumiai or Japan Seamen's Union (JSU). The organisation was firmly in the hands of the non-communists, and its leadership was in contact with ITF. In October 1929, the JSU affiliated with the ITF. In addition, the JSU belonged to a group of unions that founded the left-wing but anti-communist Rodonominto or Labour-Farmer (WorkersPeasants) Party in 1926. Nevertheless, members of the disbanded CPJ managed to join the Labour-Farmer Party and gradually came to occupy strategic positions in the party. In the same year, an underground Communist Party was reconstituted. In 1927, the Comintern intervened and instructed the CPJ to organise itself as a vanguard party, working with and within mass organisations like the Labour-Farmer Party. The latter became the legal platform for the left in Japan and, among others, joined the international 'Hands off China'-campaign. Accused for its links with the communists and the illegal CPJ, Japanese authorities banned the Labour-Farmer Party in April $1928 .{ }^{62}$

The RILU regarded the transformation of the Japan Seamen's Union into a revolutionary union to be futile. According to an assessment of the trade union movement in Japan by Japanese Comintern member Sen Katayama in 1926 , there existed four seamen's unions with a total membership of 47,500 . Some of them represented the upper echelon of the seamen and, according to Katayama, had few connections to the labour movement. "All of them are conservative and possess little class consciousness," he concluded. ${ }^{63}$ Agitation and propaganda work among Japanese seamen was not possible inside Japan and was at this point concentrated to Vladivostok. However, the Vladivostok Port Bureau faced several constraints, not least the lack of functionaries who were fluent in the Japanese language. The Port Bureau cooperated with the exile

61 Boris Slavinski, The Japanese-Soviet Neutrality Pact: A diplomatic History, 1941-1945 (London and New York: RoutledgeCurzon, 2004), 13.

62 See further Nishida Yoshiaki, "Labour and Farmers' Movements in Prewar Japan," in Political Economy of Japanese Society, ed. Banno Junji (New York: Oxford University Press, 1997), 237-276.

63 Sen Katayama, "Latest Development of the Trade Union Movement in Japan," Inprecor 6, no. 25 (1 April 1926): 396-397. 
Japanese comrades who published a Japanese bulletin once a month but its editor was criticised in a confidential report for not being "politically fitted." ${ }^{4}$

Similar hopes for prospective communist activities and agitation also existed for Indonesia during the early 1920s. The mastermind of the Indonesian Communist Party (PKI) and its policy of a united front between the nationalists and communists was the Dutch communist Hendrick Sneevliet. He was also a key figure in the Dutch East Indies labour movement. ${ }^{65}$ Apart from Sneevliet, the two prominent figures in the Indonesian Communist Party and labour movement were the Javanese Semaoen (Semaun, ca. 1899-1971) and Tan Malaka (1897-1949). The former had started as a railway worker in Java but quitted his job to become a full-time activist in the Vereeniging van Spoor-en Tramweg Personeel or Union of Train and Tramway Personnel (VSTP) in 1915. Being at first a member of the (Dutch) Indies Social Democratic Association and the nationalist Sarekat Islam, he became the first chair of the PKI in May 1921. He was exiled to Amsterdam in 1923 after the Dutch colonial government had crushed a general strike and Tan Malaka took over as leader of the PKI. In Amsterdam, Semaoen headed the PKI bureau. ${ }^{66}$

Semaoen was also president of the Sarekat Pegawai Laoet Indonesia (SPLI), the Union of Indonesian Seamen, which he had established in Amsterdam in 1924. At this point, the SPLI-office functioned as headquarters of the PKI abroad. As Ruth McVey notes, the SPLI was the partner of the Serilagu, i.e., the Semarang-based Serikat Laut dan Gudang (Union of Seamen and Dockers). Both associations aspired to organise the 24,000 Indonesian seamen employed on ships operated by the Rotterdam Lloyd Company and the Netherlands Steamship Company. The key idea was to organise groups on each large steamship and harbour installation in which they were active, with a "consul" in charge of each group. The consuls, in turn, would serve as couriers for the PKI. ${ }^{67}$

The 1924 Canton Conference of the Transport Workers of the Orient spurred communist trade union activities in Indonesia. Semaoen wrote a lengthy report about the prospects for work in October 1924. His main concern was the Serilagu that, according to him, had recently emerged as a hub for radical

64 Cuen to Achkanov, Confidential Report [handwritten], [Vladivostok] 25.3.1927, 534/5/187, 104, RGASPI.

65 Anna Belogurova, "Communism in South East Asia," in The Oxford Handbook of the History of Communism, ed. Stephan A. Smith (Oxford: Oxford University Press, 2014), 236-251.

66 Cheah Boon Kheng, From PKI to the Comintern, 1924-1941: The Apprenticeship of the Malayan Communist Party (Ithaca, NY: Cornell University South East Asia Program, 1992), 126.

67 Ruth T. McVey, The Rise of Indonesian Communism (Ithaca: Cornell University Press, 1965), 215 . 
activities as it had discharged its "reactionary" leaders. Not surprisingly, the Dutch authorities banned the union. ${ }^{68}$

In December 1924, the PKI decided to reactivate the VSTP as a means to expand its trade union activities and intensify its propaganda in communistcontrolled unions. In addition, the plan was to re-establish new unions, among others, the Serilagu. In addition, the Indonesian Red Trade Union Secretariat (Secretariaat Vakbonen Merah Indonesia) was established in Surabaya and was affiliated to the Pan-Pacific Trade Union Secretariat in Guangzhou. As a result, Surabaya emerged as a major centre for communist trade union activity in 1925, counting 9oo members in the VSTP, 2,000 in the machine shop workers' union and 1,500 in the Serilagu. ${ }^{69}$

In February 1925, the Serilagu merged with the local harbour workers' and seamen's unions of Surabaja and Batavia, formed the Serikat Pegawai Pelabuhan dan Lautan (SPPL) or Indonesian Seamen's and Dockers' Union, and affiliated with Samoen's Amsterdam-based sPLI. One month later, the SPLI-headquarters were moved to Indonesia and were merged with the SPPL office. ${ }^{70}$ The SPPL, in turn, joined the Indonesian Red Trade Union Secretariat and announced that it would internationally link up with the Port Bureaus and offices set up (or planned to be set up) under RILU auspices. ${ }^{71}$ In 1925, British intelligence sources claimed that the SPPL had established close connections with the People's Partnership in Malaysia. In Indonesia, the SsPL spearheaded the formation of the Federation of Indonesian Trade Unions. The Federation, in turn, received funding from Moscow via Guangzhou, British intelligence stated; the key intermediate being Tan Malaka who at that point organised the connections from the Chinese port to Indonesia, Singapore, and Malaysia. ${ }^{72}$

Guangzhou, and later Shanghai and Singapore rather than Amsterdam/ Rotterdam, emerged in the mid-1920s as the main communist connection centres for South East Asia. This was due to the harsh measures adopted by the Dutch authorities in their attempt to block the transmission of communist literature, such as the Amsterdam-edited PKI journal Pandoe Merah (The Red Guide), to Indonesia. While communist activity was legal in the Netherlands,

68 Semaoen to RILU and IPC-TW, Amsterdam 16.10.1924, 534/5/163, 54-55, RGASPI.

69 Takashi Shiraishi, "Policing the Phantom Underground," Indonesia 63 (April 1997): 4, 13.

70 McVey, The Rise of Indonesian Communism, 276, 461. The SPLI claimed at this point to list some 3,0oo seamen and 9,00o dockworkers rank and file members (McVey, The Rise of Indonesian Communism, 442).

71 McVey, The Rise of Indonesian Communism, 276-277.

72 Kheng, From PKI to the Comintern, 8; Leon Comber, Dalley and the Malayan Security Service, 1945-48: MI5 vs. MSS (Singapore: ISEAS Yusof Ishak Institute, 2019), 62. 
the Dutch colonial authorities prohibited the dissemination of communist literature in September 1924, and started to arrest seamen who carried illegal literature and post to the Dutch East Indies. ${ }^{73}$

However, as Jean Duval notes, Indonesia was never identified by the Comintern as one of its main regions of operation, and was too remote and inaccessible for effective intervention by Moscow. The P KI leaders in Indonesia, Duval claims, conceived revolution as a putsch, an event that would trigger off a general uprising. ${ }^{74}$ The Dutch repressed strike waves in 1924 and 1925. In December 1925, the PKI decided to prepare for insurrection, a plan heavily criticised by its exiled leaders Semaoen and Tan Malaka but they were incapable to influence the subsequent cause of events. The communist uprising in late 1926 had not the backing of Moscow and ended in a disaster for the communists. The Dutch colonial government crushed the uprising and arrested 13,00o persons after the revolts. A few of them were shot, 4,50o were sentenced to prison after trial, about one thousand interned. The PKI and its affiliated associations and organisations, including the Red Trade Union Secretariat, were banned and destroyed. Communist agitation and activities, in turn, went underground, became clandestine and tried to infiltrate nationalist non-communist organisations. ${ }^{75} \mathrm{The} \mathrm{RILU}$, too late and post factum, tried to unleash an international protest campaign against colonial brutalities in the Dutch East Indies. ${ }^{76}$

\subsection{Challenging Work: Indian, Arab and African Seamen}

Communist agitation and propaganda among the unions of maritime transport workers in the Indian sub-continent, in the Arab world as well as in subSaharan Africa proved difficult during the early 1920s. This was due to several reasons. Maritime transport workers' associations existed in India but the British colonial authorities rigorously controlled union activity. Besides, union

73 Tony Saich, The Origins of the First United Front in China: The Role of Sneevliet (alias Maring) (Leiden: Brill, 1991), 723.

74 Jean Duval, "The First Period of the Indonesian Communist Party (PKI): 1914-1926," 29 August 2005, https://www.marxist.com/indonesian-communist-party-pki2ooo.htm (checked 26.4.2020).

75 McVey, The Rise of Indonesian Communism;Audrey R. Kahin, “The ${ }_{1927}$ Communist Uprising in Sumatra: A Reappraisal," Indonesia 62 (October 1996): 19-36; Michael C. Williams, Sickle and Crescent: The Communist Revolt of 1926 in Banten (Singapore: Equinox Publishing, 2010). See further Harry J. Benda and Ruth T. McVey, The Communist Uprisings of 19261927 in Indonesia: Key Documents (Singapore: Equinox Publishing, 2009), and Klaas Stutje, Campaigning in Europe for a Free Indonesia: Indonesian Nationalists and the Worldwide Anticolonial Movement, 1917-1937 (Copenhagen: NIAS Press, 2019).

76 "Manifesto of the RILU on the Revolt in Indonesia," Inprecor 6, no. 84 (2 December 1926): 1438 . 
functionaries and leaders effectively impeded the formation of a radical leftwing opposition within the unions. Moreover, the ambitions for affiliating the All-India Trade to the RILU and the PPTUS were staved off by the mid-1920s. Infiltrating the seamen's union in India had little effect, and even more frustrating was the work among unorganised Indian seamen and dockworkers. ${ }^{77}$ Even less promising was the situation in the British and French colonies and mandated areas in the Near East where union activities was minimal. Almost nil potentials for a revolutionary trade union movement seemed to exist in Sub-Saharan Africa as Moscow could not identify an existing class-conscious working-class outside South Africa.

Together, the three macro-regions posed a strategic challenge not only for the Comintern and RILU but also for the IPC-TW. The solution to the Indian problem was to focus on Indian seamen residing outside India and to shift the attention to European ports. Arab and African seamen, too, were included in the considerations, although it took several years for Moscow to frame a distinctive approach towards the latter group. The basic idea was that the national communist parties and revolutionary opposition groups in the colonial metropoles were either to promote the establishment of exterritorial branches of 'colonial' - Indian, Arab or African - seamen's union in European ports or to open the respective national seamen's unions for non-white members. Not surprisingly, the national unions in Europe rejected both strategies.

The communist approach towards non-white maritime transport workers in Europe was both novel and radical. If successful, it would have opened a new chapter in the organisation of maritime transport workers. The foundations for such an approach certainly existed and was a consequence of the global 'steamship revolution' during the latter part of the nineteenth century. During this period, the employment of non-white unskilled maritime worker of different ethnic backgrounds became a marked feature on European and US American merchant vessels. ${ }^{78}$ During the first decades of the twentieth century,

77 "Tätigkeitsbericht des IPAK," in Die 5. Internationale Konferenz der Revolutionären Transportarbeiter, 48. See further Carolien Stolte, "Bringing Asia to the World: Indian trade unionism and the long road towards the Asiatic Labour Congress, 1919-37," Journal of Global History 7 (2012): 257-278.

78 Jonathan Hyslop, "Steamship Empire: Asian, African and British Sailors in the Merchant Marine c. 1885-1945," Journal of Asian and African Studies 44, no. 1 (2009): 49-67; Ravi Ahuja, "Mobility and Containment: The Voyages of South Asian Seamen, c. 1900-196o," International Review of Social History 51, S14 (2006): 111-141. See further Diane Frost (ed.), Ethnic Labour and British Imperial Trade: A History of Ethnic Seafarers in the UK (London: Routledge, 1995), and Ray Costello, Black Salt: Seafarers of African Descent on British Ships (Liverpool: Liverpool University Press, 2012). 
their number counted already tens of thousands. Indian seamen, known as "lascars", ${ }^{79}$ constituted the largest group or circa 10 percent of the 240 , ooo seamen employed on British merchant vessels in the early 189 os, rising to 52 ,000 or 17.5 percent in 1914, and 25 percent during the 1920 and $19305 .{ }^{80}$ Gopalan Balachandran estimates that the total number of colonial seamen amounted to nearly 235,000 in the 193 os. $^{81}$

A common nominator among white maritime workers in post-war Europe and the USA was the fear of losing their job to colonial workers. The task of the national unions was to defend the position of their members instead of propagating the unrealistic gospel of international or even racial solidarity; at best, trade unionism was what Jonathan Hyslop defines as "white labourism." ${ }^{82}$ Consequently, non-white workers above and below deck were not protected by the unions; they received lower wages, worse accommodation and smaller daily rations than white workers on board the ships. Their homes in the port cities were located in peripheral quarters with notorious or dubious reputation. ${ }^{83}$

79 The term lascar was pejorative, racial, and blurred the fact that the so-called Indian seamen comprised a great diversity of ethnic and religious groups. See further F.J.A. Broeze, "Muscles of Empire - Indian Seamen and the Raj 1919-1939," The Indian Economic and Social History Review 18, no. 1 (1981): 43-67.

8o Figures from Gopalan Balachandran, "South Asian Seafarers and Their Worlds, c. 18701930s," in Seascapes: Maritime histories, littoral cultures, and transoceanic exchanges (2007), 186-202, available at http://webdoc.sub.gwdg.de/ebook/p/2005/history_cooperative/www.historycooperative.org/proceedings/seascapes/balachandran.html (checked 28.1.2020). See further Gopalan Balachandran, Globalising Labour? Indian Seafarers and World Shipping, 1870-1945 (New Delhi: Oxford University Press, 2012).

81 Gopalan Balachandran, "Conflicts in the International Maritime Labour Market: British and Indian seamen, employers, and the state, 1830-1939," The Indian Economic \& Social History Review 39, no. 1 (2002): 77. See further Marika Sherwood, "Race, Nationality and Employment among Lascar Seamen, 166o to 1945," Journal of Ethnic and Migration Studies 17, no. 2 (1991): 229-244; Marika Sherwood, "Lascar Struggles Against Discrimination in Britain 1923-45: The Work of N.J. Upadhyaya and Surat Alley," The Mariner's Mirror 9o, no. 4 (2004): $438-455$.

82 Jonathan Hyslop, "The imperial working class makes itself 'White': White labourism in Britain, Australia, and South Africa before the First World War," Journal of Historical Sociology 12, no. 4 (1999): 398-421. See further Michael Quinlan and Constance LeverTracy, "From Labour Market Exclusion to Industrial Solidarity: Australian trade union responses to Asian workers, 1830-1988," Cambridge Journal of Economics 14, no. 2 (June 1990): 159-181, and David Featherstone, Solidarity: Hidden Histories and Geographies of Internationalism (London: Zed Books, 2012), 71-72.

83 See further Diane Frost, "Racism and Social Segregation: Settlement patterns of West African seamen in Liverpool since the nineteenth century," Journal of Ethnic and Migration Studies 22, no. 1 (1996): 85-95; Diane Frost, "Diasporan West African Communities: the Kru in Freetown and Liverpool," Review of African Political Economy 
Racial discrimination and white chauvinism gained momentum in Britain when a post-war slump in British trade and shipping resulted in racial tension and conflicts, leading to riots and attacks on Indian and black (African and Caribbean) seamen in the United Kingdom. ${ }^{84}$ The British government responded to the 'race riots' of 1919 by introducing the Coloured Alien Seamen's Order in 1920, aiming to regulate and restrict the employment of foreign, especially Chinese, African and Caribbean seamen. Little sympathy was received from the National Sailors' and Firemen's Union (NSFU), renamed National Union of Seamen (NUS) in 1926, who rather backed discriminatory government policies, culminating in the amendment and expansion of the Coloured Alien Seamen's Order in 1925, and the introduction of the PC $5^{85}$ card in 1930 as a system to register seamen looking for work. ${ }^{86}$

Discontent with the "white laborism" of the NSFU was initially voiced by a few of its black members, most notably Harry O'Connell and Chris Braithwaite. O'Connell, a Cardiff-based mariner from British Guiana, led a deputation of three 'coloured' seamen from Cardiff and criticised the discrimination of black union members at a meeting of the executive council of the NSFU in $1922 .{ }^{87}$ Braithwaite, a London-based mariner from Barbados who worked as NFSU/ NUS organiser and functionary of the Shipping Federation, clashed with NFSU officials about the barring of Asian and black seamen from the British labour market in $1920{ }^{88}$ The two were later to emerge as the key organisers of the

29, no. 92 (2002): 285-300; Gopalan Balachandran, "Subaltern Cosmopolitanism, Racial Governance and Multiculturalism: Britain, c. 190o-45," Social History 39, no. 4 (2014): $528-546$.

84 Neil Evans, "Across the Universe: Racial Violence and Post-war Crisis in Imperial Britain, 1919-25," Immigrants and Minorities 13, no. 2-3 (1994): 58-88.

85 Under the PC5 or Port Consultant's system, any seamen who wanted to get a job needed an identification card signed and stamped by the Shipping Federation and the National Sailors' and Firemen's Union. The PC5-card effectively blocked "unwanted" seamen as the union only passed the card to its paying members. See further Basil Mogridge, "Militancy and Inter-Union Rivalries in British Shipping, 1911-1929," International Review of Social History 6, no. 3 (1961): 399.

86 Laura Tabili, "The Construction of Racial Difference in Twentieth-Century Britain: The Special Restriction (Coloured Alien Seamen) Order, 1925," Journal of British Studies 33, no. 1 (1994): 54-98.

87 David Featherstone, "Harry O'Connell, maritime labour and the racialized politics of place," Race \& Class 57, no. 3 (2016): 74. O'Connell founded the Cardiff Coloured Association during the 1920s, see further Hakim Adi, "The Cominern and Black Workers in Britain and France 1919-37," Immigrants and Minorities 28, no. 2-3 (2010): 236.

88 Christian Høgsbjerg, Chris Braithwaite: Mariner, Renegade \& Castaway. Seamen's Organiser, Socialist and Militant Pan-Africanist (London: Socialist History Society \& Redwords, 2014), 27-28. 
radical black waterfront in Britian; both of them joined the Communist Party of Great Britain or CPGB in the late 1920 and were active in the Seamen's Minority Movement (see below). George Hardy, then RILU organiser in Britian, tried to present the communist position as a 'multi-ethnic alternative' in his 1927 pamplet on the aims and objectives of the Minority Movement. "The Laskar, Chinaman, Arab or West African Negro" were not to be blamed for the loss in wages, overtime and condition on British vessels, he reminded his (white) readers, "the policy of the shipowners is to 'divide and conquer'. Ours is to unite internationally, East and West [...]." 89

The situation was not much better elsewhere. In the USA, black mariners were discriminated by Jim Crow legislation in the US South and by white chauvinism and blatant racism in the seamen's unions. ${ }^{90}$ Chinese and Japanese maritime workers suffered on the US Pacific. ${ }^{91}$ The only exception was the Iww who tried to enlist Asian and black seamen and strived for interracial unionism. However, by the mid-192os, the Iww had lost its momentum. ${ }^{92}$ In France, too, black and Asian seamen and harbour workers were regarded as secondclass, unskilled workers. ${ }^{93}$

British shipping principally employed Indian seamen as a way of replacing organised/unionised high-cost white mariners with relatively unorganised low-cost non-white crew members. ${ }^{94}$ Indian seamen were lowest paid, and cost less to house and provision on board than European or even Arab or Chinese seamen. They also worked longer hours, typically 84 hours a week. Trade union organisation was rudimentary but did exist, such as the Asian Seafarer's Union for deck personnel as well as the Indian Seamen's Union for engine room personnel, both established in 1918. The two unions merged in 1919, legalised in 1926 and were officially registered in 1927 as the National Seamen's Union of India. Neither the Raj, the British colonial state, nor the shipping industry were

89 George Hardy, The Struggle of British Seamen (London: Transport Workers' Minority Movement, Seamen's Section. Published for the International Propaganda Committee of Transport Workers), 26. For a critical discussion on Hardy's division between British seamen and seafarers of 'colour', see Featherstone, Solidarity, 88.

90 Gerald Horne, Red Seas: Ferdinand Smith and Radical Black Sailors in the United States and Jamaica (New York and London: New York University Press, 2005).

91 Fowler, Japanese and Chinese Immigrant Activists.

92 See further Darlington, Syndicalism and the Transition to Communism.

93 Gérard Noiriel, Immigration, antisémitisme et racism en France $\left(X I X^{e}-X X^{e}\right.$ siècle). Discours publics, humiliations privies (Paris: Karthala, 2007); Sylvain Pattieu, "Souteneurs noirs à Marseille, 1918-1921. Contribution à histoire de la minorité noire en France," Annales. Historie, Sciences Sociales 64, no. 6 (2009): 1361-1386.

94 See further G. Balachandran, "Recruitment and control of Indian seamen: Calcutta 188o1935," International Journal of Maritime History 9, no. 1 (1997): 1-18. 
in favour of Indian union activity and thwarted union activism. Consequently, membership appears to have been some 300-400 core men of all rank in Mumbai (Bombay) and Kolkata (Calcutta), the two main places of organised union activities. During the 1920s, the National Seamen's Union of India sought affiliation with the ITF but the latter was lukewarm in addressing the plights of the Indian seafarers. ${ }^{95}$

Communist agitation among Indian maritime transport workers was characterised by recurrrent setbacks during the 1920s. As work in India was effectively checked by union leadership, shipowners and the colonial authorities, the ambition was to interact with Indian mariners in the United Kingdom. This was to be the task of the Communist Party and the revolutionary minorities in the trade unions. Basically, the idea was to promote associations for Indian seamen in British ports and to link up with them. However, this plan backfired almost immediately as neither the party nor the revolutionary minority within the unions seemed to be unwilling to do so. Work within the unions remained confined to white British maritime transport workers. ${ }^{96}$

The second strategy proposed by the IPC-TW, namely to approach 'colonial' seamen through the Port Bureaus and Interclubs in Britain, also backfired. The intial plans for opening Port Bureaus in London and Liverpool with special purpose of working among Indian seamen had to be shelved due to the incapacity and organisational restrictions of the British Party and the Minority Movement. ${ }^{97}$ However, IPC-TW Secretary Achkanov raised the question anew in early 1927 and ordered the Minority Movement to organise a Port Bureau and, if possible, an Interclub in London "in the near future." This plan, he reported, had been accepted by the IPC-TW, the RILU and the British Section of the Comintern. ${ }^{98}$ Most importantly, his instructions included a blueprint for work among 'colonial' seamen in London: The projected Port Bureau was to employ an Indian seaman for work among Indian as well as Arab and "other colonial" seamen..$^{99}$ This, it seems, was the first time when the IPC-TW referred to other than Indian seamen in their tactical considerations on work among 'colonial' seamen.

95 Balachandran, "South Asian Seafarers and Their Worlds."

96 See further Sarah Glynn, Class, Ethnicity and Religion in the Bengali East End: A political history (Manchester: Manchester University Press, 2016).

97 Atschkanow, Bericht des I.P.K.T. über die Hafenbüros, 1.12.1926, 534/5/178, 67, RGASPI.

98 Achkanov to Minority Movement London, Moscow 25.2.1927, 534/5/186, 62, RGASPI.

99 [IPC-TW,] Work among Seamen in Britain, no date [February 1927; the document is an attachment in Achkanov's February 1927-letter to the Minority Movement], 534/5/186, 66-68, RGASPI. 
Operations in London were slow to start. Achkanov urged Minority Movement leader Harry Pollitt in April 1927 to consult Clemens Palme Dutt, the head of the CPG в Colonial Bureau, about identifying a suitable Indian seaman. ${ }^{100}$ Achkanov must have regarded the latter as the key link to the Indian community in Britain. Together with Nathanal Jagivan Upadhyaya and Ajoy Banerji, Dutt had been active in organising Indian seamen in London and had visited Liverpool several times in an attempt of organising Indian seamen. ${ }^{101}$ This must have resonated well with Achkanov whose blueprint for the two envisioned Port Bureaus included a close cooperation with local Indian associations. ${ }^{102}$ However, it was Upadhyaya (1895-?) who was the key agitator among Indian seamen. He had arrived in Britian in 1922 and soon connected with the communists for whom he recruited Indians, organised meetings, distributed litterature and wrote articles. In 1925, he was instrumental in founding the Indian Seamen's Union in London, assuming himself the role of secretary and organised meetings to protests against the application of the Coloured Alien Seamen's Order and against racial discrimination of Indians. ${ }^{103}$ Not surprisingly, the British colonial authorities branded the Indian Seamen's Union as a being nothing else than a communist- and Comintern-controlled organisation. ${ }^{104}$

The main concern of British authorities at home and in India was the claim that Indian seamen were lured by communists to act as agents and vehicles of anti-colonial agitation in India. Hamburg and Marseille, especially, were identified by them as subversive 'hotspots' during the 1920 s as Indian seamen would call at these ports and were believed to be enlisted as carriers of

100 Achkanov to Harry Pollitt, Moscow 15.4.1927, 534/5/186, 79, RGASPI. The Colonial Bureau or Colonial Commission of the CPGB had been established in 1925. It was an attempt to form connections in India, Palestine, China, Egypt and Ireland. George Hardy was present at its meetings in fall 1931 when Upadhyaya's case was up for discussion, see entry for 24.8.1931, George Hardy personal file, KV 2/1027, TNA.

101 "Clemens Palme Dutt," The Open University, Making Britain: Discover how South Asians shaped the nation, 1870-1950, available at http://www.open.ac.uk/researchprojects/makingbritain/content/clemens-palme-dutt (checked 28.1.2020).

102 Atschkanow, Bericht des I.P.K.T. über die Hafenbüros, 1.12.1926, 534/5/178, 68, RGASPI.

103 Marika Sherwood, "Lascar struggles against discrimination in Britain". On Upadhyaya, see further "Nathalal Jagivan Upadhyaya," Making Britain: Discover how South Asians shaped the nation, 1870-1950, http://www.open.ac.uk/researchprojects/makingbritain/content/ nathalal-jagivan-upadhyaya (checked 21.5.2020).

104 Muhammad Ali Raza, Interrogating Provincial Politics: The Leftist Movement in British Punjab, c. 1914-1950, PhD thesis, Oxford University, 2011, 46. On the attempts to radicalise Indian seamen, see further Muhammad Ali Raza, Revolutionary Pasts: Communist internationalism in colonial India (Cambridge: Cambridge University Press, 2020). 
subversive litterature if not arms, as Ali Raza and Benjamin Zachariah have outlined. ${ }^{105}$ The assumption of the British secret police proved right. In late 1927, the Indian communist Nalimi Gupta notified Moscow about the situation in the two ports. Although there was no regular shipping service from Hamburg to India, Gupta reported, the port was of substantial interest for the communists as a large number of Indian seamen visited Hamburg. ${ }^{106}$ What is interesting in Gupta's communication is his claim that the "International Transport Union refuss[es] to pay" for its operations in Hamburg and Marseille or its activities in India. He might be referring to the International Propaganda Committee of Transport Workers. If this is the case, then Gupta's letter is one of the few documents hinting about a subversive dimension of the IPC-TW. Or, perhaps it is the opposite - the IPC-TW had not been informed about the plans of the Indian revolutionaries and its Port Bureau in Hamburg rejected to support clandestine operations unless ordered to do so by the headquarters in Moscow?

Thus, whereas work among Indian seamen in Britain had achieved some limited success by 1927, work among Arab and African seamen was yet to start. Until then, neither IPC-TW nor the RILU had paid any attention towards them. The main reason, it seems, was the lack of information in Moscow on existing maritime transport workers' unions in the British mandated areas and colonies in the Middle East and Africa. In addition, it even seems as if the Comintern and RILU headquarters were not aware of the existence of Arab and African proletarian diaspora communities in Britain.

A rather different situation prevailed in France where African, Arab, and Asian (mainly Vietnamese) maritime workers constituted a target group for the communists. However, agitation in the French ports proved as viscous as in Britain. This must have been a disappointment as the Comintern considered the political conditions for communist agitation to be much better in France than in Britain. In 1924, the Comintern even established a Colonial Bureau in Paris, tasked to cooperate with the Colonial Commission of the French Party as well as to supervise its anti-colonial work in the French colonies. ${ }^{107}$ Local

105 Ali Raza and Benjamin Zachariah, "To Take Arms Across a Sea of Trouble: The "Lascar System," Politics, and Agency in the 1920s," Itinerario 36, no. 3 (December 2012): 19-38.

106 Nalim Gupta to Secretary [name cut away] (Eastern Section) Moscow, no date (stamped: 1 Jan. 1928), 534/5/194, 4, RGASPI. As the letter is archived in the RILU-archive (fond 534), it is likely that Gupta addressed his letter to someone at the RILU headquarters rather than the Comintern Eastern Secretariat.

107 Mustafa Haikal, "Das Internationale Kolonialbüro der Komintern in Paris," Jahrbuch für historische Kommunismusforschung (1993): 126-130. 
functionaries opened a Port Bureau in the same year and managed to connect with African and Asian seamen. ${ }^{108}$ However, operations in Paris came to a standstill when the French Surreté deported Manabendra Nath Roy, the head of the Colonial Bureau in Paris, in early $1925 \cdot{ }^{109}$

The organisation of the (radical) African diaspora in France gained momentum a few years later, first with the foundation of the Comité de Défense de la Race Nègre and, after its split in 1927, the radical Ligue de Défense de la Race Nègre (LDRN). The LDRN, headed by the Senegalese Communist Lamine Senghor (1889-1927) and Garan Tiemoko Kouyaté (1902-1942) from the French Soudan (Mali), received financial support from the French Communist Party PCF. Most importantly, however, Kouyaté had links to black seamen and dockworkers in the French ports. ${ }^{110}$ In 1927, a Port Bureau started operating in Marseille, the main centre for colonial maritime transport workers in France. ${ }^{111}$

\subsection{Bleak Prospects? The 1926 Montevideo Conference and Work in Latin America}

Left-wing syndicalism had made its roads to South America already before the war. In general, the unions were small and the national federations weak and most of them were dominated by the syndicalist International Workers of the World of IWw. In Chile and Mexico, the Iww had its strongest foothold among seamen and dockworkers, but also attracted other transport workers, bakers, shoemakers and female factory workers. In Chile, the main stronghold of the IWW was the port of Valparaiso where it mustered some 9,0oo members during the early 1920s. Interestingly, it was at Valparaiso where exiled Tom Barker arrived in 1918. In Mexico, the IWw branch was formally established in 1919 and had its main stronghold in the port of Tampico with some 6,ooo members, too. In Ecuador, they controlled the port of Guayaquil, in Uruguay the port of Montevideo. ${ }^{12}$ A first attempt to summon the radical left-wing maritime transport workers was made by the Marine Transport Workers' Industrial Union (MTWIU) of the IWW in at a conference in New Orleans in 1925. Harrison

\footnotetext{
108 Atschkanow, Bericht des I.P.K.T. über die Hafenbüros, 1.12.1926, 534/5/178, 6o, RGASPI.

109 Haikal, "Das Internationale Kolonialbüro."

110 See further Philippe Dewitte, Les mouvements nègres en France, 1919-1939 (Paris: L'Harmattan, 1985).

111 "Tätigkeitsbericht des IPAK," in Die 5. Internationale Konferenz der Revolutionären Transportarbeiter, 39 .

112 See further Anton Rosenthal, "Radical Border Crossers: The Industrial Workers of the World and their Press in Latin America," Estudios Interdisciplinarios de America Latina y Caribe 22, no. 2 (2011): 44-53.
} 
George (1888-?),, ${ }^{113}$ a militant IWw-member who had joined the communists and tried to use the MTWIU as a vehicle to establish a communist-controlled international maritime organisation, participated at the conference which also listed several delegates from South America. A second gathering had originally been scheduled to be held in Havana, but had to be transferred elsewhere due to a military coup d'état and the establishment of the Machado dictatorship in Cuba. Eventually, the MTWIU organised the conference in Montevideo. ${ }^{114}$

Communist agitation among maritime transport workers had made little inroads in Latin America during the early 1920s. The exception was Uruguay where the socialists under leadership of Eugenio Gomez (1892-1973) managed to control the port workers' union, the Federación Obrera Marítima (FOM), at the end of the 1910s. In September 1920, a fraction within the Socialist Party led by Gomez accepted the 21-Points of Membership to the Comintern and became the Partido de Comunista Uruguay (PCU). This was magnificent news from Moscow's perspective. In contrast to other Latin American states, the PCU gained legal status and could operate in public. Even more important, as the PCU had grown out of the trade union movement, its prime objective was to propel a communist trade union movement and to compete with the anarcho-syndicalist Federación Obrera Regional Uruguaya (FORU) and the socialist Unión General de Trabajadores. The main vehicle for communist agitation was the communist-controlled maritime union that had joined the antianarchist Comité Pro Unidad Obrera. ${ }^{115}$

Nevertheless, the communists failed to infiltrate the Comite Pro Unidad Obrera and compel its affiliation to the RILU. Reorganised as the Unión Sindical Uruguaya (USU) in 1923, the union leadership effectively blocked any further communist attempts to control the union. Although officially denounced as 'anarchist', the communist remained and constituted a revolutionary minority group within the USU. Union work itself was facing stiff challenges at the same time as the economy was in a state of depression. Consequently, membership in the unions declined from 10,200 in 1922 to 6,500 in 1926, divided among numerous small unions. ${ }^{116}$

\footnotetext{
113 On Harrison George and his work for the Comintern and RILU, see Harvey Klehr, John Earl Haynes and Fridrikh Firsov, The Secret World of American Communism (New Haven: Yale University Press, 1995), 49-57.

114 Tosstorff, The Red International of Labour Unions, 466; Vernon L. Pedersen, The Communist Party on the American Waterfront: Revolution, Reform, and the Quest for Power (Lanham: Lexington Boos, 2020), 7.

115 Robert J. Alexander, A History of Organized Labor in Uruguay and Paraguay (Westport: Praeger, 2005), 25-26.

116 Alexander, A History of Organized Labor in Uruguay and Paraguay, 27.
} 
From Moscow's perspective, therefore, work in Latin America opened both potentials and challenges. At the Comintern headquarters, the so-called Latin Secretariat monitored organisational matters concerning the activities of the parties on the continent. ${ }^{117}$ In 1925, the Comintern established a Latin American Secretariat in Buenos Aires to strengthen its supervision of the parties in Latin America. ${ }^{118}$ The RILU, too, planned to open an office in South America; an opening to make this move occurred in March 1926 when the Second Continental Conference of Marine Transport Workers convened in Montevideo. The main manager and organiser of the conference was Harrison George. ${ }^{119}$

Harrison George arrived at Montevideo and delivered a lengthy speech that seemingly impressed his audience. ${ }^{120}$ Present at the venue were mainly representatives from syndicalist harbour worker associations and federations from Brazil, Uruguay, and the USA, those from Mexico, Cuba and Peru had cancelled their attendance due to financial constraints while the delegation from the Argentinian Maritime Federation arrived late and missed the event. Although the syndicalist leanings were strong at the conference, Harrison George managed to convince them about Moscow's idea of centralism and trade union unity. As an outcome of the negotiations, a unity committee, known as the Comite Continental de Obreros Maritimos y Portuarios, was established. The Comite Continental was to promote the Iww's programme of militant struggle but adhere to the RILU programme of 'World Trade Union Unity'. Its headquarters was to be set up in Montevideo and its main project was to summon a new congress within the next two years. ${ }^{121}$

The conference also accepted and published a thirteen-point programme of concrete demands that encapsulated the demands for improving the conditions of the maritime transport workers "in their united struggle." Echoing

117 The Latin American Section of the Secretariat of the Comintern was established in 1921. In 1926, it was renamed as the Latin Secretariat and supervised the parties in the "Latin" countries in Europe, including Belgium, France, Spain and Portugal, and in Latin America. The secretariat was split in 1928, and the Latin American Secretariat existed until 1935. The Anglo-American Secretariat, in turn, supervised the parties in Australia, Canada, Ireland, New Zealand, the Philippines, South Africa, the United Kingdom, and the USA.

118 Manuel Caballero, Latin America and the Comintern 1919-1943 (Cambridge: Cambridge University Press, 1986), 26-27; Silvio Pons and Robert Service (eds.), A Dictionary of 2othCentury Communism (Princeton and Oxford: Princeton University Press, 2010), 197.

119 Pedersen, The Communist Party on the American Waterfront, 7.

120 Speech of Harrison George - representative of the IPCT at the United Front Conference of the Marine Workers of the Western Hemisphere, held at Montevideo March 20-21, 1926, it was delivered in Spanish [English translation], 534/5/185, 16-28, RGASPI.

121 Harrison George, “The Western Marine Workers' Conference at Montevideo," Inprecor 6, no. 48 (24 June 1926): 794-795. 
earlier resolutions of the IPC-TW, they summarised the visions of the revolutionary trade union opposition and its call for radical union activism in an eight-point declaration:

1) Eight-hour working days for seamen and six hours for stokers;

2) 44-hour week for all maritime workers that have an eight-hour day,

3) Holiday work at double time and overtime double the present rate;

4) Uniform scale of wages for seafarers of all countries on equal ships an equal lines;

5) Uniform number of personal in crew,

6) Vacation with pay after six months service, two weeks for deckhands, one month by stokers;

7) Full wages and passage home for workers discharged or left in foreign ports,

8) Right to leave ship at will in any port, without punishment or loss of pay,

9) Dining rooms for crews with all comforts;

10) Tub and shower baths for crews;

11) Establishment of the cabin system for crews, with all sanitary conditions;

12) Unions to be consulted when new ships are planned, to assure good conditions for the workers;

13) The recognition of ship committees, composed of representatives from all departments of the same ship. ${ }^{122}$

These demands were revolutionary in a world where seamen and stokers had few rights and even less comfort on board merchant vessels, and they were to constitute the core demands of the communists over the next decade. What was new - the national unions had similar demands on their programme - was the uncompromising urge of the communists for the immediate realisation of the demands instead of a prolonged period of tactical negotiations.

Controlling the activities of the Comite Continental or Montevideo Bureau proved difficult, if not impossible. Dispatches from Montevideo took months to reach Moscow making it difficult for the RILU and IPC-TW secretariats in Moscow to react and respond to, not to speak interfere with practical planning and tactical considerations. Correspondence and, most likely funding [?], was sent via the RILU Berlin Bureau, where Max Ziese functioned as intermediary. ${ }^{123}$ In June 1927, the Comite Continental informed Moscow that it decided

\footnotetext{
122 George, "The Western Marine Workers' Conference at Montevideo," 795.

123 P. Garcia to Achkanov, Montevideo, [?] February 1927, 534/5/192, 1, RGASPI. In this letter, Garcia informs Achkanov about the contacts via Max Ziese. Achkanov replied in April that he had received the letter, see Achkanov to Garcia, Moscow 14.4.1927, 534/5/192, 5, RGASPI. I have not (yet) been able to identify P. Garcia.
} 
to focus on the maritime unions in Argentina, Brazil, Chile and Paraguay. ${ }^{124}$ Agitation within the FOM in Uruguay was not necessary as the communists already controlled the union. However, no further information was forthcoming for the rest of the year, and the RILU and IPC-TW headquarters must have suspected that the communist or revolutionary groups within the maritime transport workers' unions were either insignificant or out of reach of Montevideo's and, by extension, Moscow's control.

Moreover, the lack of a Port Bureau and/or Interclub in South America hampered the ambitions of the IPC-TW. Initially, the IPC-TW planned to establish a Port Bureau in Buenos Aires in 1926 but a lack of suitable functionaries nullified these plans. ${ }^{125}$ In April 1927, Achkanov requested the Comite Continental to make a new attempt. ${ }^{126}$ A Port Bureau in Buenos Aires was of top priority, Achkanov stressed - the city was the largest port in South America and the terminus for twelve international steamship lines. ${ }^{127}$ Nothing happened and a new start was needed for work in South America. At a meeting in Moscow in mid-December 1927, the RILU therefore announced its intention to set up a Latin American Trade Union Secretariat in Montevideo. ${ }^{128}$ Bureaus

The Port Bureaus focussed on agitation and propaganda among foreign seamen. While this was the sole objective of the units in Soviet Russia, those operating outside Soviet Russia also attracted native mariners as well as local harbour workers, which generated confusion among local functionaries about the focus and scope of their work. The root cause of this was a conflicting interpretation of the spatial dimension of a Port Bureau's operational framework. Ideally, a Port Bureau constituted an extra-territorial unit and served as a link between the IPC-TW, and by extension the RILU, and the various national red trade unions or revolutionary minorities and oppositions within the national trade unions. The organisational structure was further complicated as the IPCTW started to set up regional secretariats and sub-secretariat in 1925 to monitor and supervise the operations outside Soviet Russia, see Table 1.

\footnotetext{
124 P. Garcia to Achkanov, Montevideo, 11.7.1927, 534/5/192, 7, RGASPI.

125 Atschkanow, Bericht des I.P.K.T. über die Hafenbüros, 1.12.1926, 534/5/178, 67, RGASPI.

126 Achkanov to Garcia, Moscow 14.4.1927, 534/5/192, 5, RGASPI.

127 Atschkanow, Bericht des I.P.K.T. über die Hafenbüros, 1.12.1926, 534/5/178, 67, RGASPI.

128 "Towards a Latin American Trade Union Secretariat," Inprecor 7, no. 72 (22 December 1927): 1636 .
} 
TABLE 1 The regional units of the IPC-TW, ca. 1927/1928

\begin{tabular}{|c|c|c|c|}
\hline Location & Secretariat & Subordinated Countries & Port Bureau \\
\hline Berlin & $\begin{array}{l}\text { Central European } \\
\text { Secretariat }\end{array}$ & $\begin{array}{l}\text { Austria, Czechoslovakia, } \\
\text { Germany, Hungary, the } \\
\text { Netherlands, Poland, } \\
\text { Switzerland }\end{array}$ & $\begin{array}{l}\text { Hamburg, } \\
\text { Rotterdam }\end{array}$ \\
\hline Paris & Latin Secretariat & $\begin{array}{l}\text { Algeria, Belgium, France, } \\
\text { Italy, Palestine, Portugal, } \\
\text { Spain, Syria, as well as } \\
\text { the French colonies }\end{array}$ & $\begin{array}{l}\text { Bordeaux, } \\
\text { Marseille }\end{array}$ \\
\hline Oslo & $\begin{array}{l}\text { Scandinavian } \\
\text { Secretariat }\end{array}$ & $\begin{array}{l}\text { Denmark, Finland, } \\
\text { Iceland, Norway, Sweden }\end{array}$ & $\begin{array}{l}\text { Copenhagen } \\
\text { [Plan: Oslo] }\end{array}$ \\
\hline London & British Secretariat & $\begin{array}{l}\text { Ireland, United Kingdom, } \\
\text { as well as the British } \\
\text { colonies }\end{array}$ & [plan: London] \\
\hline [?] & $\begin{array}{l}\text { North American } \\
\text { Secretariat }\end{array}$ & Canada, USA & New York \\
\hline Montevideo & $\begin{array}{l}\text { Latin American } \\
\text { Secretariat }\end{array}$ & $\begin{array}{l}\text { Argentina, Bolivia, Brasil, } \\
\text { Chile, Paraguay, Peru, } \\
\text { Uruguay }\end{array}$ & $\begin{array}{l}\text { [plan: Buenos } \\
\text { Aires] }\end{array}$ \\
\hline [?] & $\begin{array}{l}\text { Sub-Secretariat } \\
\text { for the Baltic } \\
\text { countries }\end{array}$ & Estonia, Latvia, Livonia & \\
\hline [?] & $\begin{array}{l}\text { Sub-Secretariat } \\
\text { for the Balkan } \\
\text { countries }\end{array}$ & $\begin{array}{l}\text { Albania, Bulgaria, } \\
\text { Greece, Romania, Turkey, } \\
\text { Yugoslavia }\end{array}$ & \\
\hline Shanghai & $\begin{array}{l}\text { Sub-Secretariat } \\
\text { for the Far Eastern } \\
\text { countries }\end{array}$ & $\begin{array}{l}\text { China, India, Indonesia, } \\
\text { Japan, Korea, Pilippines }\end{array}$ & [plan:Shanghai] \\
\hline [?] & $\begin{array}{l}\text { Central American } \\
\text { Secretariat }\end{array}$ & $\begin{array}{l}\text { Colombia, Cuba, } \\
\text { Ecuador, Mexico, } \\
\text { Nicaragua, Venezuela }\end{array}$ & \\
\hline [?] & $\begin{array}{l}\text { Sub-Secretariat for } \\
\text { Australia and the } \\
\text { Pacific countries }\end{array}$ & $\begin{array}{l}\text { Australia, New Zealand, } \\
\text { US West Coast }\end{array}$ & [plan: Sydney] \\
\hline
\end{tabular}

SOURCE: DIE 5. INTERNATIONALE KONFERENZ DER REVOLUTIONÄREN TRANSPORTARBEITER, ABGEHALTEN IN MOSKAU APRIL 1928 (MOSKAU: INTERNATIONALES PROPAGANDA- UND AKTIONSKOMITÉE DER REVOLUTIONÄREN TRANSPORTARBEITER, 1928), 74 
The geographical location for some of the secretatiats and sub-secretariats is difficult to establish due to the paucity of available sources. Only a few of them can be traced, others were listed in the publication of the Fourth IPC-TW Conference only by names but without any information on their location. ${ }^{129}$ The Central European, British and Latin Secretariats seemed to have been attached to or worked in tandem with the RILU-units in Berlin, London and Paris, and supervised acivities at the Port Bureaus in Hamburg and Rotterdam (Berlin) as well as Bordeaux and Marseille (Paris). The operations of the unit in Oslo, the Scandinavian Secretariat, and the Port Bureau in Copenhagen will be discussed in detail further below. The location of the North and Central American Secretatiats of the IPC-TW is unclear/not known; I assume that they were either located in Moscow or in New York, perhaps in tandem with the Trade Union Educational League, the RILU-unit in the USA. Similar speculations apply to the Baltic and Balkan Sub-Secretariats; my hyptothesis is that they were located in Moscow, the Baltic one perhaps in Riga?

The unit in Montevideo was the Comite Continental; it operated from mid1929 in conjunction with the Confederación Sindical Latino Americana (CSLA), the new RILU-unit for Latin America. The CSLA had been established at a congress in Montevideo held in May 1929. The establishment of the CSLA also affected the operations of the IPAC-TW in Latin America. A detailed assessment of the files in the Comintern Archives on the attempt to radicalise and organise maritime transport workers Latin America is still missing but research literature and contemporary documentation enables a rough sketch of the organisational outline after 1929. In congruence with the Montevideo Congress in May 1929, a conference for maritime transport workers was organised by the Federación Obrera Marítima of Uruguay. Headed by Eugenio Gómez and attended by representatives of unions in Brazil, Colombia, Paraguay, Peru and Uruguay, the conference resulted in the establishment of the Comité Marítimo y Portuario Latino Americana. ${ }^{130}$

The location of the Pacific Sub-Secretariat is dubious. Perhaps it was a unit that was planned to be placed in Sydney? The operations of the IPC-TW in the Far East and the Pacific area were constrained due to the insecure working

129 My discussion of the location of the IPC-TW secretariats and sub-secretariats revises my earlier identification, especially with regards my suggestion of locating some of the units in Hamburg, see Weiss, För kampen internationellt, 87, table 1.

130 Alexander and Parker, International Labor Organizations and Organised Labor in Latin America and the Caribbean, 53. At least some of the correspondence and reports by the Comité Marítimo y Portuario for 1929 is filed in 534/5/207, 534/5/212, and 534/5/218, all RGASPI. 
conditions in Shanghai where the RILU-units existed as underground offices from 1927 onwards. Public activities in the Shanghai harbour were more or less impossible, including agitating foreign seamen. A new structure for work in the Pacific area were laid in August 1929 when the Second Conference of the Transport Workers of the Pacific convened in conjunction with the Second Pan-Pacific Trade Union Conference held in Vladivostok. The key role of organising seamen, especially the so-called "coloured" or non-white, was stressed by the PPTUS. This became the key objective of the Pan-Pacific Secretariat of Transport Workers or TOST, formed at the conference and with temporary residence in Vladivostok. At first, the TOST was run by the Finn Väinö Pukka as secretary, the Japanese member Takasaki, the Chinese member and former instructor at the defunct Shanghai Interclub Kichi, and the Japanese member and editor of the Vladivostok Interclub's Japanese newsletter Saiki Shinzo (alias Kavata). Its main task was to publish and disseminate periodicals and non-periodical publications in Chinese and Japanese language. The тоsт co-operated with the Vladburo, established in December 1929 as the central co-ordinating unit of the RILU in Vladivostok, and the local Port Bureau and Interclub which were under the direction of the Vladburo. ${ }^{131}$ In contrast to the Comité Marítimo y Portuario Latino Americana, the Pan-Pacific Secretariat of Transport Workers was not affiliated to the successor of the IPC-TW, the International Action and Propaganda Committee of Transport Workers.

Initially, the IPC-TW had planned to open Port Bureaus in Petrograd and Odessa as well as outside Russia in Antwerp (Belgium), Buenos Aires (Argentina), Constantinople (Turkey), Genova (Italy), Gothenburg (Sweden), Hamburg (Germany), Liverpool (Britain), Marseille (France), New York (USA), Piraeus (Greece), Port Said (Egypt), and Rotterdam (Netherlands). ${ }^{132}$

However, the vision of a global network of radical maritime propaganda centres never materialised. What had come into existence by 1926 was a truncated version of the grand plan. Not surprisingly, the establishment of Port Bureaus in Soviet Russian ports was a rather easy affair as the Bolsheviks were in full control of Russia by 1922. Within the next year, the IPC-TW operated Port Bureaus in Archangelsk, Novorossiysk, Odessa and Petrograd (from 1924: Leningrad), followed by those in Batumi, Feodosia, Kherson, Mariupol, Murmansk, Nikolayev (Mykolaiv), Poti, and Vladivostok. In addition, the IPCTW was running so-called liaison centres for the distribution of literature among seamen in Berdyansk, Nikolayevsk-on-Amur, Sebastopol, and Tuapse. Outside Soviet Russia, the vision proved difficult to accomplish, and Port

\footnotetext{
131 Fowler, Japanese and Chinese Immigrant Activists, 83-84, 111.

132 Atschkanow, Bericht des I.P.K.T. über die Hafenbüros, 1.12.1926, 534/5/178, 56, RGASPI.
} 
Bureaus existed only in four ports by 1926, namely Bordeaux, Copenhagen, Hamburg and Rotterdam. In addition, the IPC-TW was operating a liaison centre in Shanghai. ${ }^{133}$ One year later, the situation had changed. Operations in Shanghai went underground due to the suppression of communist activities by the Guomindang. On the other hand, positive news were the opening of a Port Bureau and Interclub in Marseille as well as an Interclub in New York. ${ }^{134}$

The functionaries of the Port Bureaus rather than the regional secretariats approached foreign seamen when they visited vessels while moored in a harbour. The visits had two purposes. The ambition of the functionaries was to assemble the crew and distribute propaganda literature as well as to invite them to visit the premises of the Port Bureau. Here, the crew was to find the International Seamen's Club or Interclub that operated in conjunction with the Port Bureau. The Interclub was the public space of the Port Bureau, and usually consisted of a library and a reading room, often a bar or a restaurant. Here, the functionaries of the Port Bureau organised meetings and discussion events as well as film, music or theatre shows. In addition, they invited the crew to excursions and sport events. ${ }^{135}$ Ideally, each Interclub comprised several language sections, usually defined as the Anglo-American, German, Latin or Scandinavian sections. A few of them also listed Chinese and Japanese sections. However, the number of sections varied according to the availability of functionaries fluent in foreign languages or representatives who had been detached by a national party or a revolutionary opposition/minority to work at a specific Interclub. This turned out to be a handicap of all Interclubs during the $1920 .^{136}$

The core mission of a Port Bureau was political agitation and propaganda as well as the organisation of revolutionary cells and committees on board the ship. The task was to disseminate the decisions and resolutions of the Comintern and RILU as well as the directives of the IPC-TW. Their main propaganda tool was the magazine, periodical and wall journal produced by the functionaries and seamen who visited the Interclub and published by the Port Bureau. In addition, the Port Bureaus were to establish and to maintain

\footnotetext{
133 Atschkanow, Bericht des I.P.K.T. über die Hafenbüros, 1.12.1926, 534/5/178, 56, RGASPI.

134 Internationale kommunistische Hafenbüros, included in report by the German police on the communist movement in Germany, dated Berlin 15.10.1927, Reichskommissariat für Überwachung der öffentlichen Ordning und Nachrichtensammelstelle im Reichsministerium des Inneren, R 1507/2035, BarchB. According to police informants, a liaison office (rather than an outright Port Bureau) existed in Duisburg-Ruhrort in a small tavern close to the harbour. However, the existence of such an establishment at this point can be doubted as there are no reference to it in the contemporary correspondence from the Hamburg Port Bureau to the RILU Berlin Bureau.

135 Atschkanow, Bericht des I.P.K.T. über die Hafenbüros, 1.12.1926, 534/5/178, 57-58, RGASPI.

136 See further Weiss, För kampen internationellt!, 416.
} 
contacts to the revolutionary opposition and minorities in the national unions of maritime transport workers. In some cases, the Port Bureau functionaries represented national unions or the minorities/revolutionary opposition within the unions as well as served as arbitrators to settle disputes among the crew or between the crew and the captain. In addition, their assignment was to instigate campaigns in support of national conflicts. ${ }^{137}$

The most visible activity of the Port Bureaus were their appeals for international proletarian solidarity, which at times caused concern for the shipowners and government authorities. Some of these campaigns were politically motivated, such as the global 'Hands off China'- campaign of the Comintern and RILU that called for demonstrations against British interventions in China during the mid-1920s, or the call of the RILU to protest against Dutch imperialism in Indonesia in 1926. Most of the international campaigns orchestrated by the Port Bureaus, however, were in support of national strikes, such as the British and Australian seamen's strike in 1925, the seamen's strike in Sweden in 1925, and the British miners' and general strike in 1926. 138

Local political conditions constituted a major barrier for establishing and running a Port Bureau. Objectively, this was not the case in Soviet Russia, although internal reports by liaison agents of the bureaus sometimes criticised local Soviet party, police and trade union officials for obstructing work among foreign seamen. As early as 1923, the RILU initiated an assessment of the operational basis of the Port Bureaus in Russia. ${ }^{139}$ The commission, headed by Grigorii Achkanov, heavily criticised the Port Bureaus for their lax commitment to agitation and propaganda work among foreign seamen. ${ }^{140}$ As a consequence, work in the Russian Port Bureaus was overhauled, and especially the Leningrad Port Bureau emerged as a key operational node (see Figure 4) ${ }^{141}$ In contrast, the situation was more difficult outside Soviet Russia where the union, police

137 Atschkanow, Bericht des I.P.K.T. über die Hafenbüros, 1.12.1926, 534/5/178, 57-58, RGASPI.

138 Atschkanow, Bericht des I.P.K.T. über die Hafenbüros, 1.12.1926, 534/5/178, 57-58, RGASPI; “Tätigkeitsbericht des IPAK," in Die 5. Internationale Konferenz der Revolutionären Transportarbeiter, 22-23. On the British seamen's strike of 1925 and its international dimensions, see further B. Hirson and L. Vivian, Strike Across the Empire: The Seamen's Strike of 1925 in Britain, South Africa and Australasia (London: Clio Publications, 1992); Jonathan Hyslop, "A British Strike in an African Port: The mercantile marine and dominion politics in Durban, 1925," The Journal of Imperial and Commonwealth History 43, no. 5 (2015): 882-902. The seamen's strike in Sweden has not received academic attention.

139 Protokoll Nr $5^{8}$ der Sitzung des Vollzugsbüros der Profintern vom 8.8.1923, 534/3/46, RGASPI.

140 Protokoll Nr 64 der Sitzung des Vollzugsbüros der Profintern vom 6.9.1923, 534/3/46, RGASPI.

141 Protokoll Nr 67 der Sitzung des Vollzugsbüros der Profintern vom 29.9.1923, 534/3/46, RGASPI. 


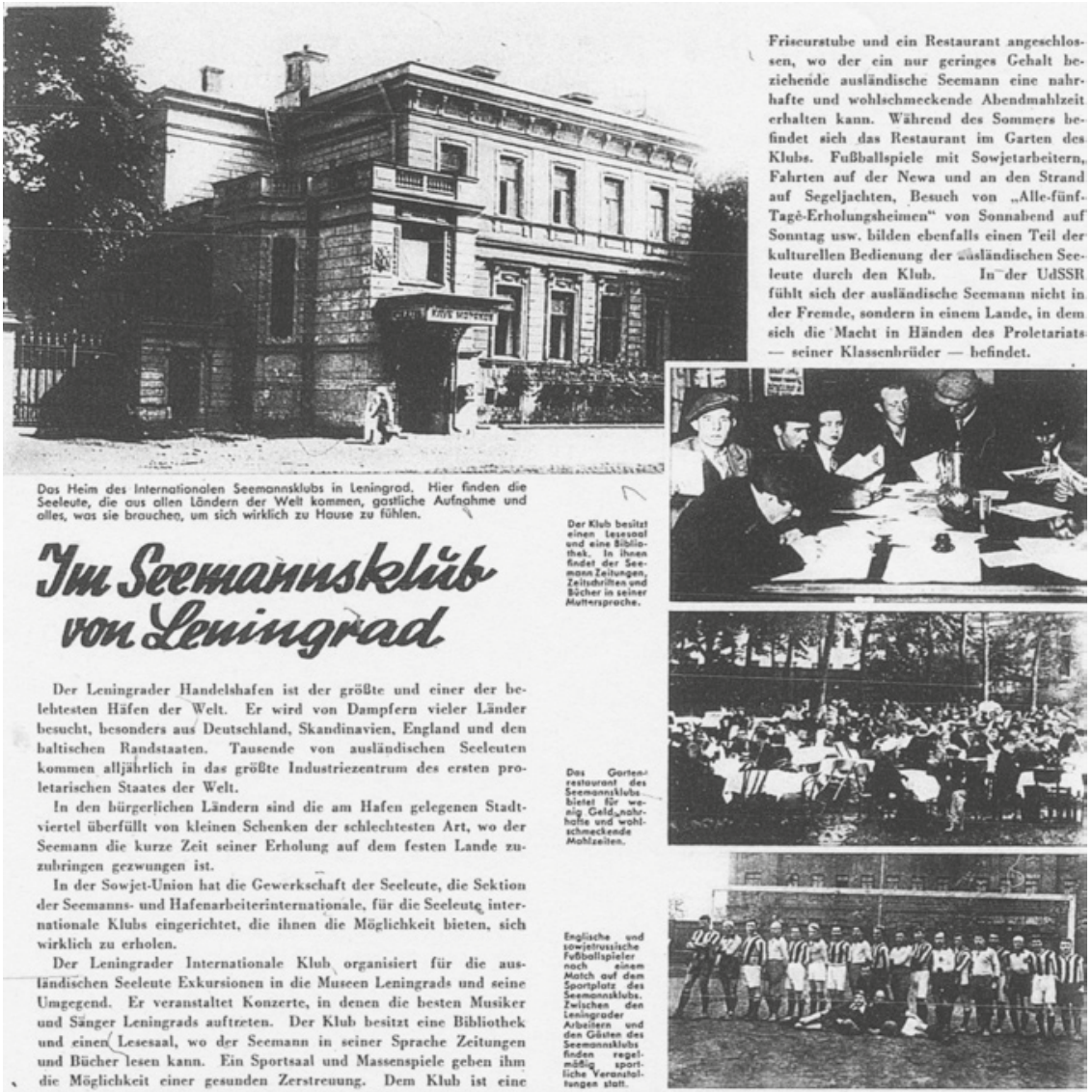

FIGURE 4 The Leningrad Interclub, article published in Arbeiter-Illustrierte Zeitung XI, no. 44 (1932): 1058. The Interclub was renovated and enlarged in 1932. After the extension, the Interclub was added with a boarding house for visiting seamen, a large buffet restaurant, a gym, and a library.

and port authorities as well as the shipowners and the non-communist parties either blocked or thwarted the efforts of the communists and revolutionary opposition groups. In some places, IPC-TW Secretary Achkanov lamented, the Communist Party and communist-controlled unions either had an indifferent attitude or were incapable of assisting a Port Bureau. ${ }^{142}$

The lukewarm interest of the local communist party and union leaders towards the Port Bureaus was due to its position within the communist

142 Atschkanow, Bericht des I.P.K.T. über die Hafenbüros, 1.12.1926, 534/5/178, 56, RGASPI. Although not directly stated, Achkanov's critique about the disinterest of the Communist Party seems to have been directed towards the CPGB and CPUSA. 
world-system. Whereas national communist parties constituted sections of the Comintern and red trade unions sections of the RILU, the Port Bureaus operated outside the control of a national party, a red union or a revolutionary opposition/minority. Instead, the Port Bureaux was - at least on paper-directly subordinated to a regional IPC-TW secretariat and, ultimately, headquarters in Moscow. In practice, however, the situation was more complicated. In Soviet Russia, the management of a Port Bureau consisted of its secretary who represented the IPC-TW, three representatives of the local branches of the railway, water transport and motor transport unions as well as to a representative of the local party unit for agitation and propaganda. Outside Soviet Russia, a Port Bureau consisted of fewer salaried officials, in most cases only the secretarycum-representative of the IPC-TW and a representative of the local red union or revolutionary minority within the transport workers' union..$^{143}$

The (relatively) independent position of the Port Bureaus in relation to the local party and red unions/minorities was due to its designation as agitation and propaganda unit for reaching out to foreign seamen. Most Port Bureaus had functionaries who spoke at least one, sometimes even several languages. This was usually a foreign seaman who had been enlisted by the Port Bureau to target vessels flying the flag of a nation which language the seaman mastered. In some cases, the person also acted as liaison person for one or several national maritime unions. This was, among others, the case in the Leningrad and Archangelsk Port Bureaus whose functionaries had the mandate to represent Scandinavian and German maritime unions (see further below).

\subsection{Foreign Seamen in Soviet Ports}

The first Port Bureau and Interclub was established in Petrograd (Leningrad) in 1922, located in an old palace of the Russian nobility surrounded by a large garden at 15, Prospect Ogorodnikova. Although the interior of the palace witnessed of its former grandeur, it had been transformed into a political space by the Bolsheviks by placing a large bronze statue of Lenin in the vestibule. Large signposts on the doors oriented a visiting seamen to a specific section, such as the Anglo-American, Colonial, French, German or Scandinavian, which were in charge of work among various national seamen. The building further hosted a library, a gym and a large dining hall. ${ }^{144}$

Leningrad was the largest and most important port of Soviet Russia, and was regularly visited by German and Nordic merchant vessels. Consequently,

\footnotetext{
143 Atschkanow, Bericht des I.P.K.T. über die Hafenbüros, 1.12.1926, 534/5/178, 56-57, RGASPI.

144 Eröffnung des Internationalen Seemannsklubs in Leningrad, Deutsche Botschaft. Deutsches Generalkonsulat Leningrad, 8.6.1932, R1501/20224, 126, BArchB.
} 
the most important sections of at the Interclub were the German and the Scandinavian ones. Both were organised by the German communist Hermann Knüfken who also was the secretary of the Interclub. ${ }^{145}$ In addition, Knüfken was the local representative of the Seamen's section of the German Transport Union (Deutscher Verkehrsbund, Abteilung Seeleute), the Norwegian Seamen's and Stokers' Union (Norsk Matros- og Fyrbøterunion), the Danish Stokers' Union (Søfyrbødernes Forbund), and the Danish Seamen's Union (Sømændenes Forbund i Danmark). ${ }^{146}$ On the other hand, although both Swedish and Finnish vessels regularly called at Leningrad, the national unions of these two countries had no representative at the Interclub.

The Leningrad Port Bureau and Interclub emerged as the leading unit of the IPC-TW. In 1927, some 24,000 foreign seamen had visited the Interclub, of which 1,500 participated in excursions to factories and cultural institutions whereas 5,00o engeged in sporting events. All of them made use of the library and reading hall, and 8,0oo attended music events and concerts. ${ }^{147}$

The other Soviet Port Bureaus had a more limited outreach and scope of activities. Norwegian merchant vessels predominated in Archangelsk. ${ }^{148}$ British, French, Greek, and Italian ships, in turn, dominated the Black Sea ports. The Interclub in Novorossiysk included a Latin Section that focussed on work among French, Greek, Italian and Spanish seamen, and an Anglo-American one for British, Dutch, German, North American and Scandinavian seamen. ${ }^{149}$ Key functionary in Novorossiysk was the Italian communist Luigi Polano, who started a campaign against the Fascist regime in Italy in February 1927, and edited an anti-fascist and anti-syndicalist bulletin, Il Lavoratore Rosso dal Mare, which was sent to the Interclubs in Marseille, New York and Rotterdam for distribution among Italian mariners. ${ }^{150}$

145 Hermann Knüfken (1893-1976) gained acclamation and respect among the radical left when he, together with other German communists, hijacked the German steam ship Senator Schröder to Murmansk and participated at the Second World Congress of the Cominern in 1920. See further Hermann Knüfken, Von Kiel bis Leningrad. Erinnerungen eines revolutionären Matrosen 1917 bis 1930 (Berlin: BasisDruck Verlag 2008).

146 Atschkanow, Bericht des I.P.K.T. über die Hafenbüros, 1.12.1926, 534/5/178, 64, RGASPI; Daten über das Leningrader Bureau M.K.P. Transport [ca. 1927], 534/5/187, 5, RGASPI. Before the amalgamation with the German Transport Union, Knüffken had represented the Schiffahrtsbund at the Leningrad Interclub.

147 Daten über das Leningrader Bureau M.K.P. Transport [ca. 1927], 534/5/187, 5, RGASPI.

148 Atschkanow, Bericht des I.P.K.T. über die Hafenbüros, 1.12.1926, 534/5/178, 64, RGASPI.

149 [Luigi] Polano, Report [in French] on work in Novorossiysk, 15.2.1927, 534/5/187, 57-6o, RGASPI.

150 [Luigi] Polano, Report [in French] on work in Novorossiysk, 16.2.1927, 534/5/187, 61-63, RGASPI. 
Activity

1. Excursions

2. Political meetings (topic: United front)

3. Demonstrations

4. Sporting events

5. Concerts

6. Meetings

7. Interlocutions in the Club

8. Entertainment evenings

9. Meetings on board the ships

10. Discussion evenings

11. Established ship libraries

12. Visits to the club libraries

13. Wall journals and bulletins

14. Participation of crew members in preparation of wall journal and bulletins

15. Pamphlets bought by seamen

16. Pamphlets received from various organisations
Frequency Participants

$\begin{array}{rr}280 & 3,910 \\ 149 & 2,923 \\ 5 & 575 \\ 12 & 1,377 \\ 188 & 14,190 \\ 156 & 10,189 \\ 670 & 5,177 \\ 267 & 4,300 \\ 922 & 7,793 \\ 181 & 844 \\ 111 & - \\ - & 18,633 \\ 64 & - \\ - & 68\end{array}$

171

68

SOURCE: ATSCHKANOW, BERICHT DES I.P.K.T. ÜBER DIE HAFENBÜROS, 1.12.1926, 534/5/ 178,59, RGASPI

Achkanov was full of praise of the prospects and successes of the Soviet Port Bureaus in his 1926 assessment report. Almost 6o,ooo foreign seamen, representing 15 countries, had visited the five largest Soviet Port Bureaus who had organised 936 meetings, 207 excursions and 26 demonstrations in 1925. However, an analysis of the statistical data on visits to the Port Bureaus reveals that the most events counted only 10 participants. Popular ones were the concerts, meetings and sporting events, while political meetings and discussions attracted on average less than 10 persons, see Table 2.

More important than face-to-face indoctrination was the indirect one via political pamphlets and magazines at display in the reading rooms as well as the production of wall journals and bulletins by foreign seamen. In addition, the Archangelsk Port Bureau published a bulletin in German and Norwegian, while that in Vladivostok published one in Chinese, Japanese and English. ${ }^{151}$

$15^{1}$ Atschkanow, Bericht des I.P.K.T. über die Hafenbüros, 1.12.1926, 534/5/178, 66, RGASPI. 
Similar rosy descriptions about the Interclubs were circulated in the communist and left-wing press outside Soviet Russia. The German Arbeiter-IllustrierteZeitung hailed the abundant variation of sport and cultural events organised by the Leningrad Port Bureau. A foreign mariner was treated (almost) like a prince, the paper claimed; he could visit a barber or a gym at the Interclub or participate in a football game or an excursion along River Neva. Alternatively, he could visit a vacation home for recreation if he stayed over the weekend and attend concerts at the club where the best musicians of the town played classical music. ${ }^{152}$

Internally, however, criticism started to amount on the activities of the Interclubs and the conditions of work in the Soviet ports. For example, Bolshevik indoctrination generated sarcastic comments by Dutch seamen: "The [Leningrad] Club has become like a monastery and an alien space for the seamen, who are not interested to listen every evening to an inane sermon about Lenin by a landlubber."153 Critical voices were raised over the harsh rules when a seaman lost his propusk (permit) in Leningrad; the fine amounted to the equivalent to one month salary, and Knüfken begged the rule to be either liquidated or that the seamen was to be given a new propusk for free. ${ }^{154}$ Some years later, an internal memorandum heavily criticised conditions in Archangelsk. Seasonal workers at the sawmills in the Archangelsk area had climbed on board foreign ships and begged for bread and clothes from the crew. Prostitutes approached seamen in public and offered their services; illegally produced vodka was sold in the streets. The local militia did nothing; rather, they were accused for corruption and organising illegal services. Moreover, the local party and union officials had little understanding of how to approach foreign seamen and did not offer any assistance to the Port Bureau. ${ }^{155}$

The organisational setup of work among foreign seamen in the Soviet ports underwent far-reaching structural changes when the Soviet authorities subordinated the Port Bureaus and Interclubs to the Russian Union for Maritime Transport Workers in March 1927. The plans of a re-organisation must have been unknown to Achkanov when he drafted the assessment report in late 1926. The decision implied that the sole objective of the Soviet Port Bureaus and Interclubs was political propaganda about social and economic achievements

$15^{2}$ "Im Seemannsklub von Leningrad," Arbeiter Illustrierte-Zeitung XI:44 (1932): 1058.

153 R. Rohde/International Port Bureau Rotterdam to IPC-TW, Rotterdam 20.8.1924, 534/5/ 163, 32-33, RGASPI.

154 Knüfken to Achkanov, Leningrad 17.8.1929, 534/5/187, 120, RGASPI.

155 Viktor Olsen, Bericht über Archangelsk, Moskau 1929, 534/5/209, 64-65, RGASPI. 
in the 'Fatherland of the working class'. Political agitation against the shipowners among foreign seamen was restrained if not suppressed, not least the support to strikes in foreign countries. Hence, the IPC-TW refrained from addressing Russian maritime workers in its calls for international proletarian solidarity campaigns. ${ }^{156}$

The consequences of the decision in 1927 were drastic and changed the focus of the IPC-TW. While the Soviet units would officially be included in the list of Port Bureaus and Interclubs, only those outside the Soviet Union remained as agitation and propaganda centres under the control of the IPCTW. The reasons for the reorganisation were never announced or discussed in public, although it is likely that the decision followed instructions from the Kremlin. Interestingly, the decision followed the collapse of the bilateral negotiations between the All-Russian Central Council of Trade Unions and the British TUC. 157

Although officially under Russian direction and supervision, the Soviet Port Bureaus and Interclubs continued to rely on foreign functionaries to fulfil their mission. Knüfken remained in Leningrad until 1929 when the Soviet authorities arrested him for having embezzled funds from the Interclub. The accusations proved faulty, and after an international campaign for his release, the RILU transferred him to Hamburg in $1931 .{ }^{158}$ Work in Archangelsk stagnated due to the lack of functionaries who mastered Norwegian; even worse, the Interclub had ceased to publish its own journal by $1929 .{ }^{159} \mathrm{~A}$ different situation prevailed in Vladivostok where the operations of the Interclub gained a boost after the establishment of the Vladburo. ${ }^{160}$

\subsection{Gateway to the World: The Hamburg Port Bureau and Interclub}

Work at the Hamburg Port Bureau resumed its activites during spring 1924. At first, operations were run by 'Alex', presumably Nick Alexander, although it is not known if the name was an alias or not. Assumably, he left Hamburg in early 1925 and was replaced by Adolph Greenberg, who monitored the affairs of the Port Bureau until September 1925 when Albert Walter took over. Walter's main obligation had hitherto been to supervise the amalgamation of the

${ }_{15} 6$ "Bericht der Kommission über die Arbeit der Interklubs und ihre Aufgaben," in Die 5. Internationale Konferenz der revolutionären Transportarbeiter, 57-58.

157 See further Daniel F. Calhoun, The United Front: The TUC and the Russians 1923-1928 (Cambridge: Cambridge University Press, 1976).

158 Knüfken, Von Kiel bis Leningrad, 227-315.

159 Viktor Olsen, Bericht über Archangelsk, Moskau 1929, 534/5/209, 64-65, RGASPI.

160 Fowler, Japanese and Chinese Immigrant Activists, 84. 
Schiffahrtsbund with the German Transport Workers' Federation (Deutscher Verkehrsbund). ${ }^{161}$ This process was finalised in 1926 , thereafter the former communist and radical left-wing members of the Schiffahrtsbund constituted the 'revolutionary opposition' within the maritime section of the Federation, the Abteilung Seeleute.

One of the first objectives of the comrades in Hamburg was the extension and renovation of the premises of the Port Bureau. Already Greenberg noted that the bureau needed at least 4 to 5 rooms to work properly: one hall large enough to accommodate at least 15 o people for meetings and gatherings, one library, one room for entertainment and leisure, one "refreshment room" (i.e., a bar or dining room), and one room for the bureau's office. ${ }^{162}$ Renovations started in late April, and in late September the large hall and the "Bierausschank" (i.e., bar) were ready to be used. ${ }^{163}$

Work in the Hamburg harbour area faced several practical challenges. The harbour area streched over 40 square kilometres and could only be covered by the use of motorised longboats. Initially, the Port Bureau did not own its own longboat and the functionaries had to rent a vessel each time they toured the harbour for visiting ships. At times, the police prohibited the longboat drivers to carry communist agitators while some captains barred the functionaries to board a ship. Despite these restrictions, operations in the harbour area expanded and a growing amount of foreign crews were reached, see Table 3. Although the figures seem to indicate that activities had more or less collapsed in December 1925, this was not the case, Walter explained; rather, harsh weather conditions including the freezing of the harbour area prevented the use of the motorised longboat. ${ }^{164}$

The activities of the Hamburg Port Bureau expanded in 1926. Most notably, the Interclub started its operations and soon evolved as the main centre for agitation and propaganda. On average, the Interclub was visited by 1,500 to 2,00o German and foreign seamen each month. The Port Bureau had also started to edit its own journal, Der Sturm, which was published in 5,000 copies on a monthly basis, ${ }^{165}$ reaching 6,ooo in 1927 and 8,ooo in $1928 .{ }^{166}$ Until

\footnotetext{
161 Adolph Greenberg to Genosse Schachnowski, Hamburg 16.4.1925, 534/5/172, 14-15, RGASPI.

162 Adolph Greenberg to Genosse Schachnowski, Hamburg 16.4.1925, 534/5/172, 14-15, RGASPI.

163 Walter, Tätigkeitsbericht des Internationalen Hafenbüros Hamburg für September 1925, 534/5/172, 30-33, RGASPI.

164 Walter, Tätigkeitsbericht Dezember 1925, 534/5/172, 72-75, RGASPI.

165 Atschkanow, Bericht des I.P.K.T. über die Hafenbüros, 1.12.1926, 534/5/178, 66, RGASPI.

166 Internationales Hafenbüro Hamburg, Bericht März-April 1928, 534/5/201, 23, RGASPI.
} 


\section{Period Total UK USA Nor Swe Den Fra Holl Rom Ital Braz}

$\begin{array}{llllllllllll}23 \cdot 5 \cdot-18.6 . & 76 & 61 & 4 & 5 & 4 & 1 & 1 & 0 & 0 & 0 & \text { o } \\ \text { October } & 41 & 21 & 0 & 0 & 0 & 0 & 12 & 6 & 1 & 1 & 0 \\ \text { November } & 26 & 13 & 1 & 1 & 1 & 0 & 5 & 2 & 0 & 2 & 1 \\ \text { December } & 3 & 3 & 0 & 0 & 0 & 0 & 0 & 0 & 0 & 0 & \text { o }\end{array}$

SOURCE: GREENWOOD TO AMOSOV, 18.6.1925, 534/5/172, 18, RGASPI; WALTER, TÄTIGKEITSBERICHT OKTOBER 1925, 534/5/172, 41-46, RGASPI; WALTER, TÄTIGKEITSBERICHT NOVEMBER 1925, 534/5/172, 52-56, RGASPI; WALTER, TÄTIGKEITSBERICHT DEZEMBER 1925, 534/5/172, 72-75, RGASPI

( UK = UNITED KINGDOM; USA; NOR = NORWAY, SWE = SWEDEN; DEN = DENMARK; FRA = FRANCE; HOLL = HOLLAND; ROM = ROMANIA; ITAL = ITALY; BRAZ = BRAZIL $)$

1928, however, it was an illegal journal, i.e., the authorities and shipowners had banned its distribution in the harbour area. ${ }^{167}$ In July 1928, an additional magazine, Die Galeere, was launched for agitation among the crew of deep-sea fishing vessels; the first (and probably only?) issue was printed in 600 copies. ${ }^{168}$

The Hamburg Port Bureau and Interclub had four, sometimes five salaried functionaries in 1927/1928. The chief manager and secretary of the Port Bureau was "Y" or Albert Walter. Then there was "Z" whose identity is not revealed in the available documentation. The third person was "A" or Alvine; his identity is neither known. The fourth was " $\mathrm{S}$ "; this was Arthur Samising who organised work among Scandianvian seamen (see further Section 2.3 in this chapter). The fifth was "R", this was "Genosse [A.] Rath" who was replaced in Juli 1929 by a certain "Rost", probably Richard Rast. In addition, there was "Genossin Rath", seemingly Rath's wife, who was in charge of the restaurant. ${ }^{169}$ Expenses, including the printing costs of the publications, were covered by monthly transfers of funds from Moscow via the RILU bureau in Berlin, see Table $4 .{ }^{170}$

167 Walter to "Lieber Freund," no date [ca. January 1929], 534/5/207, 46, RGASPI. Walter addressed his letter either directly to Achkanov or to someone at the RILU Berlin Bureau who transferred it to Moscow.

168 Internationales Hafenbüro Hamburg, Bericht Juli 1928, 534/5/201, 4O, RGASPI.

169 Information extracted from reports on monthly expenses, attached to monthly reports for 1928 , filed in $534 / 5 / 201$, RGASPI.

170 Oplysninger vedrørende kommunistisk propaganda (april 1926), Stockholmspolisens kriminalavdelning Rotel 6 med föregångare, F x:8 Utländska kommunistiska handlingar, SNA. 
TABLE 4 Monthly transfer of funds (German Reichsmark) from Berlin to the Hamburg Port Bureau and Interclub, 1928

Jan Feb Mar Apr May Jun Jul Aug Sept Oct Nov Dec

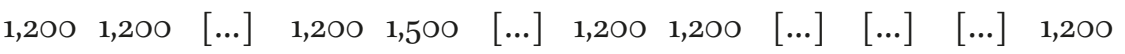

SOURCE: INTERNATIONALE HAFENBÜRo HAMBURg, MONTLY REPORTS 1928, 534/5/ 201, RGASPI

The expansion of activities by the Hamburg Port Bureau were matched by an increase in vistors at the Interclub. Soon voices were raised for larger and more suitable premises; those at hand were cramped and too small for large meetings. ${ }^{171}$ As Moscow did not respond to the complaints from Hamburg, Walter decided to act himself, and started a total overhaul and renovation of the building at Rothesoodstrasse in June $1928 .{ }^{172}$ Although headquarters in Moscow declined to support the renovation, ${ }^{173}$ Walter managed to finish it one year later. The first two floors were reserved for the Interclub and its activities. The restaurant, the reading room and the recreation room with its "Lenin corner" were located on the ground floor. Two meeting halls were located on the first floor, a larger one for 350 persons and a smaller one for 8 o persons. During special occasions, the first two floors could host up to 6oo persons. The offices of the Port Bureau as well as storage rooms were located on the second floor. ${ }^{174}$ The larger spaces were certainly needed - the Interclub listed 34,00o visitors in $1928 !^{175}$

The Hamburg Port Bureau and Interclub were more than mere agitation and propaganda centres. Albert Walter claimed that the main reason for its popularity among German as well as foreign seamen was his efforts to represent them at the local courts. Seamen visited his office to complain about abuses, excesses, infringements and maltreatment by local authorities, captains and shipping companies. Whenever possible, Walter would take their case to court. In most cases, the outcome was a positive one for the plaintiffs. Not surprisingly, this infused a positive aura of the Hamburg Port Bureau

\footnotetext{
171 Internationales Hafenbüro Hamburg, Bericht Juni 1928, 534/5/201, 81, RGASPI.

172 Internationales Hafenbüro Hamburg, Bericht Juli 1928, 534/5/201, 41, RGASPI.

173 See the negative responses to inquiries from Hamburg, filed in 534/5/207, 187 and 191, RGASPI. The former response was probably sent by Max Ziese in Berlin, the latter one by someone in Moscow.

174 Internationales Hafenbüro Hamburg, Bericht Juni 1929, 534/5/210, 66, RGASPI.

175 Internationales Hafenbüro Hamburg, Jahresbericht 1929, 534/5/210, 101, RGASPI.
} 
among radical seamen and boosted its reputation for constituting a radical free-space. ${ }^{176}$

By 1929, the premises at Rothesoodstrasse had developed into a red territory (see Figure 5). Apart from hosting the Port Bureau and the Interclub, local communist organisations started to use its halls for their meetings. Walter even claimed it had become a "red trade union building" (Rotes Gewerkschaftshaus). Such meetings and gatherings were welcomed as long as the organisers paid for their expenses - this had become the major source of income for the Interclub - but outsiders were not allowed to permanently occupy the building: its prime users were the radical maritime transport workers and the house was theirs and only, Walter declared emphatically. ${ }^{177}$

However, the Hamburg Interclub was also a contested territory. On the one hand, its premises were controlled by the club functionaries who, in turn, had to deliver monthly activity reports to Albert Walter, who headed the Port Bureau. Apart from organising the evening programme at the club and running the restaurant, the leading club functionary was also responsible for the financial balance of the activities. Nevertheless, Walter's main objective was to create an 'open space' for foreign seamen and local visitors, one that was not controlled by 'bourgeoise' and 'capitalist' autorities. On the other hand, as the communists in Germany were at loggerheads not only with the local state and police authorities but also social democratic and Nazi organisations, the Hamburg Interclub became a contested territory. A rather common feature were fistfights in the restaurant if Nazi finks tried to interup a meeting at the club, usually resulting in the arrival of a police commando to calm down the situation. Moreover, police raids were politically sanctioned and occurred either for internal or exteral reasons. Strikes in the harbour area usually unleashed a police raid against Rothesoodstrasse as both the shipowners and the bourgeoise politicians (rightly) claimed that they were orchestrated by the Interclub. Occasionally, foreign authorities criticised the German authorities for their 'lax' attitude towards international communist agencies operating in Germany, such as the Hamburg Port Bureau and Interclub. Nevertheless, as long as communist activities were legal in Germany, a police raid and closure of the Interclub was seldom a protracted affair. ${ }^{178}$

176 Internationales Hafenbüro Hamburg, Bericht Januar 1928, 534/5/201, 4-5, RGASPI; Internationales Hafenbüro Hamburg, Bericht Oktober 1928, 534/5/201, 74, RGASPI; Internationales Hafenbüro Hamburg, Jahresbericht 1929, 534/5/210, 109, RGASPI.

177 Internationales Hafenbüro Hamburg, September 1929, 534/5/210, 96, RGASPI.

178 Police raids were often reported in the internal reports, for example the raid on 1 February 1930, in Internationales Hafenbüro für Seeleute, Hamburg, Bericht Februar 1930, 534/ $5 / 216,14-15$, RGASPI, depicted as outrageous onsloughts by the "bloodhounds" in the 


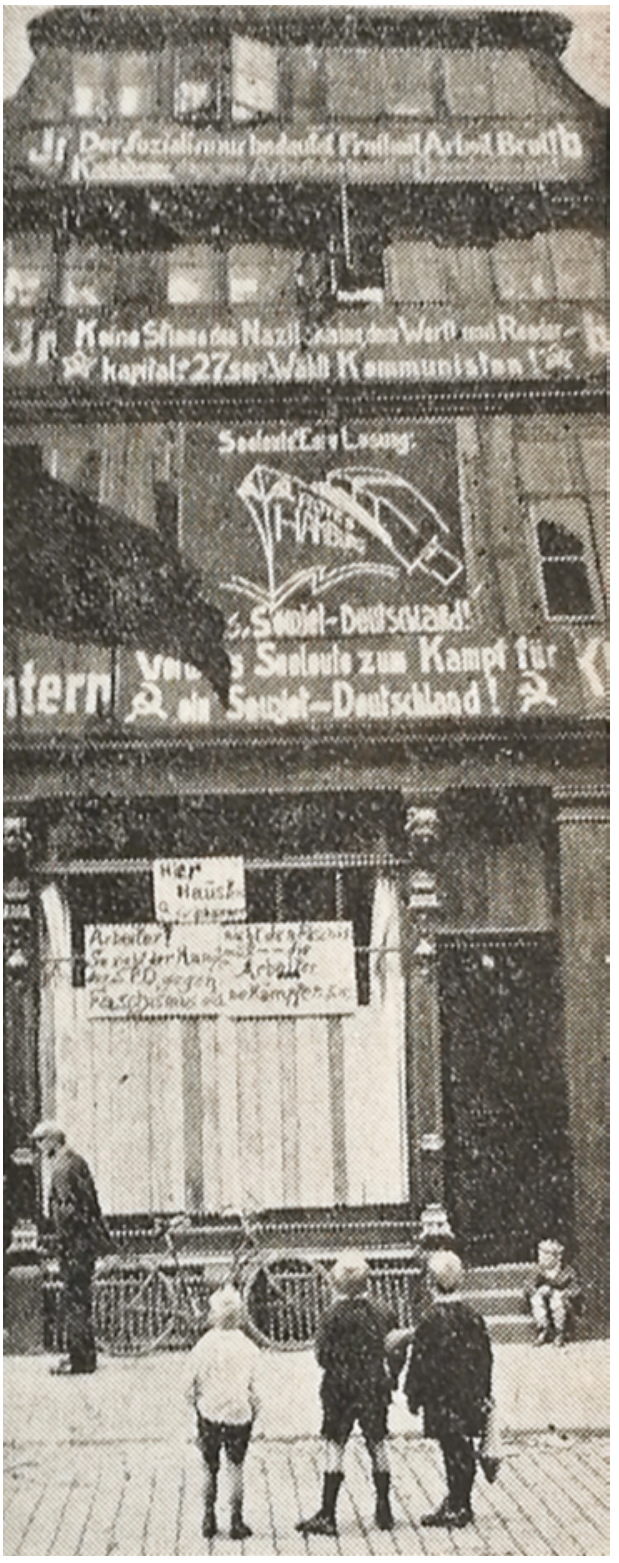

FIGURE 5 The Hamburg Interclub, photograph accompanying a presentation on the activities of the Hamburg Interclub, "Den Internasjonale Sjømansklubb i Hamburg," Internasjonal Sjøtransportarbeider 6, no. 10 (1931): 5. It is likely that the original photograph had been shot by an unknown person before the elections in Hamburg in 1931. The four-storeyed building carried banners with slogans urging the mariners to vote for the KPD. The banner in the middle of the first floor depicted a ship named 'Rotes Hamburg' and carried the slogan: Seeleute Eure Losung [...] Sowiet-Deutschland! (Mariners, your parole [is?] Soviet Germany). 


\subsection{Work among Scandinavian Seamen}

One of prime target groups of the Hamburg Port Bureau were the crews of Scandinavian cargo vessels. The reason for this was obvious: Communist activities were legal in the Scandinavian countries but the trade fleet of these countries, especially the Norwegian one, seldom called at their home ports. Work among Scandinavian seamen had therefore to be conducted outside Scandinavia, and Hamburg was one of the major ports for Scandinavian shipping. However, effective work needed a person fluent in a Scandinavian language. The Swedish comrade Smålan, who had been in charge of the Scandinavian section at the Port Hamburg Bureau and Interclub before operations were shut down in October 1923, had left Hamburg whereupon the Scandinavian section ceased operations. The section reopened in October 1925 when the Norwegian Arthur Samsing (1889-1945) arrived in Hamburg. ${ }^{179}$

Samsing was an old acquaintance of Walter. He had joined Norsk Matros- og Fyrbøterunion in 1916 and belonged to its militant left-wing minority. After the war, he had also been a member of the British General Workers' Union and the Schiffahrtsbund. In 1925, the Norwegian union sent him to London to organise its local branch and he used the opportunity instead to organise a communist fraction within the union. Samsing's period in London ended short as the British authorities expelled him for illegal activities after only a few months. He then moved to Hamburg and established a new base for his operations at the Port Bureau. One year later, he officially joined the Communist Party of Norway. Not surprisingly, the social democratic leadership of the Norwegian union was not in favour of Samsing's communist activities in Hamburg, and the union called him back in $1926 .{ }^{180}$ At this point, Samsing even raised the idea of establishing a series of Interclubs in Bergen, Oslo, Stavanger and Trondheim along the Norwegian coast, ${ }^{181}$ but nothing came out of it and he had to shelve the proposal.

Work among Scandinavian seamen resumed anew when Samsing returned to Hamburg in late 1927. This time, he was a salaried functionary of the Port Bureau.

journals of the Interclubs and IPC-TW, for example "Socialfascisternes Blodhunde i Hamborg angriber International Sømandsklub. 46 Sömænd fænglsede!” Lanternen 3, no. 2 (1930): 1; "Det socialdemokratiske bøddelpoliti i Hamburg stormer Hamburg internasjonale sjømandsklubb," Den internasjonale transportarbeier 5, no. 2 (1930): 2.

179 Walter, Tätigkeitsbericht Oktober 1925, 534/5/172, 41-46, RGASPI.

180 Autobiography, dated Leningrad 10.2.1935, Arthur Samsing personal file, 495/247/540, 5051, RGASPI; Finn Olstad, Vår skjebne i vår hand. Norsk Sjømannsforbunds historie, Bind I (Oslo: Pax, 2006), 209-210.

181 A. Samsing, "Får vi sjømansklubb i Oslo," Den Internasjonale Transportarbeider 1, no. 5 (1926): 6 . 
His sole task was to re-establish the Interclub's Scandinavian section. The kick-off event was a meeting Samsing organised at the Interclub on 7 December $1927 .{ }^{182}$ In January 1928, he published a declaration in Norwegian, informing about organising weekly meetings every Wednesday evening for Scandinavian seamen at the Interclub. ${ }^{183}$ At the same time, he started interrogating with Scandinavian crews; by the first half of 1928, he had visited 227 vessels, mainly Norwegian ones. In addition, he organised 35 meetings attended by 1,90o visitors, though only 190 of them participated at political meetings. ${ }^{184}$ Walter was highly impressed by Samsing's work; in 1928, 3,038 seamen had visited the section, and 203 of them had even participated at the 19 evening courses arranged by Samsing. 185

Another target group of Samsing's concern were unemployed Scandinavian seamen in Hamburg without any means at their disposal of returning home. Samsing's idea was to set up a support committee; its main task was to dole out financial assistance to needy Scandinavian mariners. The committee started its work in December 1928. ${ }^{186}$ Walter praised Samsings' efforts highly and Leif Foss, the head of the IPC-TW Scandinavian Secretariat in Oslo, soon recognised his organisational capacity. Foss even proposed that Samsing should return to Norway and establish an Interclub in Oslo. ${ }^{187}$ The plan was shelved for the time being due to an unexpected revision of work among maritime transport workers (see further Chapter 4.2.3), and Samsing remained in Hamburg. ${ }^{188}$ Nevertheless, Samsing's activities in Hamburg abruptly ended in early July; accused for illegal activities, the German police wanted him expelled within three days. Walter managed to extend the expulsion order by four weeks and Samsing embarked from Hamburg on 9 August 1929. 189

Samsing's successors as functionaries of the Scandinavian section were the Norwegian Fred Nilsen and a certain "Emil" whose identity is not known. ${ }^{190}$

182 "Sjømens intresse for politiske spørsmål," Den Internasjonale Transportarbeider 3, no. 1 (1928): 5 .

183 A. Samsing, "Til alle skandinaviske sjøfolk," Den Internasjonale Transportarbeider 3, no. 1 (1928): 7 .

184 A. Samsing, "Hamburg Sjømansklubb - Virksomheten bland skandinavierne," Den Internasjonale Transportarbeider 3, no. 8 (1928): 2.

185 Internationales Hafenbüro Hamburg, Jahresbericht 1928, 534/5/210, 3, RGASPI.

186 "Hjelp de arbeidsløse skandinaviske sjømenn i Hamburg," Den Internasjonale Transportarbeider 3, no. 13 (1928): 2.

187 Foss to "Georg" [Achkanov], Oslo 15.2.1929, 534/4/291, 29, RGASPI.

188 Foss to "Georg" [Achkanov], Oslo 3.4.1929, 534/4/291, 53-55, RGASPI.

189 Internationales Hafenbüro Hamburg, Bericht Juli 1929, 534/5/210, 80, RGASPI.

190 Raport fra Købenshavns Opdagelsepoliti, 17.5.1941, Politiets Efterretningstjenste, Wollwebersagen, Pakke 2, DNA. 
At this point, the Danish mariner Gustav Långfors (Langfors) also started to figure among the members of the Scandinavian section. Lacking a passport or identity card, he had roamed jobless in various European ports during the mid-1920s. In 1928, he was back in Denmark and drafted for military service but never enlisted due to ill health. In the following year, he turned up in Hamburg and started to work at the Interclub as a functionary, most likely running the Scandinavian section. ${ }^{191}$ Långfors worked closely with Albert Walter; he seems to have been fluent in several languages and translated correspondence from France, Spain and Portugal into English (Walter was fluent in English but not in Romance languages). However, Långfors' stay in Hamburg ended when the police arrested and expelled him in April 1930. ${ }^{192}$

\subsection{Rotterdam}

The Rotterdam Port Bureau put special attention on outreach to Asian and especially Indonesian seamen. This was of strategic importance as Rotterdam was the gate to the Dutch East India as well as being one of the largest ports in the world. In contrast to Hamburg, Rotterdam was an important port for American, British and Norwegian shipping industry and thousands of non-white mariners visited the port. Initially, however, the functionaries of the 1923-established Rotterdam Port Bureau faced similar problems as their colleagues in Hamburg, and work among colonial as well as foreign (white) seamen was rather limited. The Port Bureau lacked English and German-speaking functionaries, Port Bureau Secretary Langkemper complained, and business was therefore running low during its first year of operation. ${ }^{193}$ In addition, as in Hamburg, the lack of a motorised longboat hampered the activities of the Port Bureau. Neither were the premises of the Port Bureau appropriate and complaints were raised about the lack of an Interclub with a bar, a library, a reading room and a leisure room. ${ }^{194}$ Nevertheless, the Port Bureau managed to publish a journal, Rotterdamer Hafenbericht, in English and German. ${ }^{195}$ The Port Bureau mainly interacted with European crews; about 40 percent of its visitors were German and

\footnotetext{
191 Monatsbericht des Interklub/Hamburg, Januar 1930, 534/5/216, 10-12, RGASPI.

192 Internationales Hafenbüro für Seeleute, Hamburg, Bericht April 1930, 534/5/216, 21, RGASPI.

193 Langkemper/Port Bureau Rotterdam to IPC-TW, 19.2.1924, 534/5/163, 3-4, RGASPI.

194 Anlage II. Kostenvorschlag für das kommende Jahr, no date [ca. 1924], 534/5/163, 9, RGASPI.

195 Langkemper/Port Bureau Rotterdam to IPC-TW, 7·5.1924, 534/5/163, 13-18, RGASPI.
} 
30 percent Scandinavian. In contrast, the functionaries made few efforts to reach out to Asian seamen. 196

Leading members of the local trade union opposition accused Langkemper for being ineffective and incapable for organising work at the Port Bureau, and replaced him by Robert Krüger in November 1924. As the operational constraints had not changed, Krüger urged the RILU Berlin Bureau to invest in appropriate premises, not least, as the Port Bureau had started to cooperate with Norsk Matros- og Fyrbøterunion. 197

A lack of functionaries fluent in any of the Indonesian or Chinese languages hampered work among East and South East Asian seamen during the first years of the bureau's existence. Objectively, the potentials to reach out to them in Rotterdam were excellent, not least, as the communist-controlled Union of Indonesian Seamen (SPLI) had its headquarters in Amsterdam. Poor working conditions at the Port Bureau further aggravated the situation. ${ }^{198}$

Conditions for work improved in 1925 as the Port Bureau managed to move to a better location at 48 Wilhelmstraat and establish an Interclub as well as received funds from Berlin to hire its own motorised longboat. ${ }^{199}$ Consequently, visits of foreign seamen to the Interclub rapidly increased to 1,800 to 1,90o per month. Given the slow start, this were rather impressive statistics: The bureau targeted about one-tenth of all foreign crews who sojourned at the port each month. A similar number of visitors were also reported from Hamburg but those represented a much smaller portion of the total number of crews visiting the port in $1925 .{ }^{200}$

However, what really mattered was the Asian factor in Rotterdam. As outlined in detail by Kris Alexanderson, Indonesian mariners figured prominently as communist liaisons during the 1920 s. $^{201}$ They connected the PKI bureau in Amsterdam with its cells and groups in Indonesia, serving as illegal carriers and transmitters of correspondence and printed matters. ${ }^{202}$ However, government surveillance measures in the harbour area made work among Chinese,

196 Port Bureau Rotterdam, Activity Report for 23.6.-2.9.1924, 534/5/163, 35-36, RGASPI.

197 Rob. Krüger, Bericht des Rotterdamer Portbüros, 11.11.1924, 534/5/163, 6o, RGASPI; Krüger to RILU Berlin Bureau, 27.11.1924, 534/5/163, 67, RGASPI.

198 NN to IPC-TW/Comrade Sachnowsky, Amsterdam 29.1.1925, 534/5/173, 9-10, RGASPI.

199 Francois Sperbert to Schachnowsky, Rotterdam 21.4.1925, 534/5/173, 25-29, RGASPI.

200 Atschkanow, Bericht des I.P.K.T. über die Hafenbüros, 1.12.1926, 534/5/178, 61-62, RGASPI. According to port statistics, about 1,400 ships called at Rotterdam each month, with a total number of 16 ,ooo to 18 ,ooo crew members. According to Achkanov, more than 13,0oo ships had called at Hamburg in 1925 .

201 Kris Alexanderson, Subversive Seas: Anticolonial Networks across the Twentieth-Century Dutch Empire (Cambridge: Cambridge University Press, 2019).

202 Saich, The Origins of the First United Front in China, 723. 
Indonesian and Malay seamen extremely difficult. ${ }^{203}$ The Dutch authorities imposed further restrictions after the failed uprising in Indonesia in 1926, effectively curtailing the communist outreach to Indonesian seamen. In early 1927, Port Bureau Secretary E. Schneider noted that it had become almost impossible to contact Indonesian seamen as they were watched by guardians and police spies; even worse, they had stopped visiting the Interclub as the Dutch authorities had banned any contacts with communist and radical organisations and used this as an excuse for their dismissal of service. Somewhat better conditions existed for conducting work among Chinese seamen. According to Schneider, the Port Bureau itself was not directly involved in these activities. Instead, Chinese liaison persons handled the dissemination of literature as well as contacts to Chinese mariners. ${ }^{204}$

Despite its ambition to evolve as a hub for agitating Asian seamen, the Rotterdam Interclub constituted a predominantly 'white' space by 1927. Its visitors were mainly English, Dutch, German, Hungarian, Latvian, Romanian, and Scandinavian mariners who would find appeals and leaflets at display in the club in their languages: Danish, English, Estonian, French, German, Latvian, Norwegian, Russian, and Swedish. Arab and Chinese crews who visited the premises would also find publications in their language. ${ }^{205}$ Financial constrains continued to restrict activities and was a constant source of complains. ${ }^{206}$ At one stage, the Port Bureau was not even capable to hire a motorised longboat. ${ }^{207}$ Even worse was the lukewarm interest of the Dutch Communist Party to support of the Port Bureau. ${ }^{208}$ Nevertheless, the situation stabilised by the end of the year and the Interclub noted a marked increase of visitors, rising from 700 in April to almost 2,400 in December 1927. ${ }^{209}$ In addition, its German, Greek, Italian, and Norwegian functionaries had started to produce a wallpaper.

203 Sperbert to IPC-TW, Rotterdam 24.8.1925, 534/5/174, 26-27, RGASPI.

204 E. Schneider, Port Bureau and Interclub Rotterdam Monthly Report for February 1927, 534/5/190, 8-10, RGASPI.

205 E. Schneider, Port Bureau and Interclub Rotterdam Monthly Report for February 1927, 534/5/19o, 8-10, RGASPI.

206 Port Bureau and Interclub Rotterdam Monthly Report for June 1927, 534/5/19o, 47-51, RGASPI.

207 Port Bureau and Interclub Rotterdam Monthly Report for July 1927, 435/5/19o, 68-69, RGASPI.

208 NN [probably E. Schneider], International Seamen's Club Rotterdam, Report Nr. 39, Rotterdam, 12.5.1927, 534/5/19o, 27-39, RGASPI.

209 Port Bureau and Interclub Rotterdam Monthly Reports May to December 1927, 435/5/19o, RGASPI. 


\subsection{Envisioning a Global Network of Port Bureaus}

The establishment of Port Bureaux and Interclubs in Britain, France and the USA turned out to be a protracted affair. Initiatives to establish such units in London or Liverpool never materialised during the 1920s. This was largely due to the weak position of the communists and revolutionary minority within the dominant maritime transport workers' unions in the United Kingdom, the National Sailors' and Firemen's Union as well as the 1922-established Amalgamated Marine Workers' Union. Neither George Hardy's initial attempts in 1922 (see Chapter 1.2.2), nor those of Minority Movement had resulted in the formation of IPC-TW units in Britian by 1928. The situation was somewhat better in France and the USA where three units came into existence by 1927: the Port Bureaux and Interclubs in Bordeaux and Marseille as well as the Interclub in New York.

The Bordeaux Port Bureau was established in 1924. Its two functionaries mainly focused on agitation among British, Dutch, German and Scandinavian mariners. African and Asian seamen occasionally visited its premises but did not receive much attention. ${ }^{210}$ Constituting the first maritime unit of the IPCTw in France, its position was a few years later eclipsed by the Port Bureau in Marseille. This unit had been set up in 1926 but started its operations at 10, Rue Fauchier in March 1927. ${ }^{211}$ The premises of the Marseille Port Bureau were perfectly outfitted for work in the harbour. The Interclub contained a bar, a hall with a theatre scene and a library divided into sections and reflecting the language-groups whom the Interclub intended to approach: Anglo-Saxon, Annam (Vietnamese), Arab, Argentinian, Black ("Noirs"), Brazilian, Chinese, Danish, Dutch, French, German, Italian, Japanese, Norwegian, Portuguese, Russian, Spanish, and Swedish. ${ }^{212}$ The Bordeaux and Marseille units were under the direction of the IPC-TW Latin Secretariat in Paris, channelling funds from Moscow to pay for their activities. The internal allocation of funds in 1927 demonstrated the ambitions of Auguste Dumay, the head of the IPC-TW Latin Secretariat in Paris, ${ }^{213}$ to develop the Marseille Interclub into a central hub of maritime activities. While the Port Bureau in Bordeaux received about 1,500

210 Atschkanow, Bericht des I.P.K.T. über die Hafenbüros, 1.12.1926, 534/5/178, 6o, RGASPI.

211 Antoine Olivesi, "Auguste Dumay," Le Maitron: Dictionaire Biographique Mouvement Ouvier Movement Social, (24 novembre 2010), http://maitron.fi/spip.ph?article111304 (checked 14.4.2020).

212 Outline of the premises of the Interclub in Marseille, 534/5/181, 12-13, RGASPI.

213 Auguste Dumay (1888-1955) had been a militant mariner who joined the SFIO in 1917 and gained a reputation for his revolutionary activism during the 1920s. See further Antoine Olivesi, "Dumay Auguste," Le Maitron, 24.11.2010, https://maitron.fr/spip.php?article111304, checked 18.11.2020. 
Franc, the ITC-TW boosted the launching of the centre in Marseille with ca. 21,000 Franc. ${ }^{214}$ In the next year, the IPC-TW transferred 440 US dollars to both Interclubs each month. ${ }^{215}$

The establishment of an agitation and propaganda unit in New York was a protracted affair and demonstrated the limited outreach of the RILU and IPC-TW in North America. The Workers' Party (from 1925: Communist Party of the USA or CPUSA) and the Trade Union Educational League (TUEL), the RILU platform in the USA, did not consider maritime work to be of top priority. Neither had the communist or revolutionary left-wing groups within the maritime unions, the IWw-controlled Maritime Trade Workers Industrial Union and the anti-communist/anti-anarchist International Seamen's Union (ISU), the capacity and strength to push for the plan. However, what really mattered was funding. Although TUEL Secretary William Z. Foster was in favour of establishing a Port Bureau in New York, CPUSA leader Charles E. Ruthenberg replied to him as late as January 1927 that the party lacked funds for new ventures and rejected the proposal. ${ }^{216}$ It must therefore have been somewhat of a surprise when the TUEL-organ Labor Unity informed in April 1927 that an Interclub had been set up in New York. 217

The mastermind behind the New York Interclub was George Mink (1899?). Agitation and propaganda on board US merchant vessels was of prime importance, Mink recalled in his report to the Fifth IPC-TW Conference in 1928. Twenty percent of the world's shipping was carried on American vessels, 30 percent of the crew members were US natives, 10 percent US citizens of foreign extraction, the rest being foreign citizens. ${ }^{218}$ Based on a critical assessment of Russian archival sources, Vernon L. Pedersen has been able to refute earlier presentations of Mink as a somewhat mysterious if not dubious radical. Born as Godi Minkowsky in Russia, he had been abandoned by his parents and was sent by his grandparents to the USA to live with relatives in Philadelphia. In 1916, he joined the US Navy and changed his name to George Martin Mink. Discharged in 1919, he became a merchant seaman and union organiser within the International Seamen's Union. Being disappointed about the performance of the ISU in a strike in 1921, he joined the IWW. In the same year, he joined

214 C.I.P. les Transportens Pour Les Pays Latins (Paris), Rapport Financier Janvier a Decembre 1927, 534/5/205, 1, RGASPI.

215 Annexe en rapport du Dumay, 21.7.1928, 534/5/205, 2, RGASPI.

216 Theodore Draper, American Communism and Soviet Russia (New Brunswick, NJ: Transaction Publishers, new ed., second print 2009), 205.

217 "International Seamen's Club," Labor Unity 1, no. 7 (1 April 1927): 8.

218 George Mink, "The Marine Transport Industry," Labor Unity 2, no. 6 (July 1928): 5-7. 
the Worker's Party and its seamen's fraction. In 1925, after having been on the sea for several years, the party transferred him to Philadelphia with the task of building up a communist fraction within the Iww. ${ }^{219}$

Mink established the New York Interclub in March 1927 at 28, South Street. His idea was to develop the Interclub into a transnational and interracial meeting place where American and foreign seamen could interact and mingle with each other. "Fraternisation of the different races is encouraged," the Labor Union informed, and noted that "there is often a dance [after the meetings], and we may see how an Italian seaman waltzes or foxtrots with a German, or better yet witness a white seaman promenading around the hall with a Negro or Hindu." ${ }^{220}$ Soon, the Interclub gained dubious reputation for its attacks against the local Seamen's Church Institutes, resulting in an onslaught against its activities in the Seamen's Journal, the organ of the ISU. ${ }^{221}$ The party, on the other hand, remained lukewarm to the Interclub, which resulted in harsh criticism by Achkanov (although with little effect). ${ }^{222}$

\subsection{The Northern Centres: Oslo and Copenhagen}

The operations of the Scandinavian Secretariat in Oslo and the Copenhagen Port Bureau demonstrates the hierarchical and complex relationship between a regional secretariat and a Port Bureau. The basic difference of the two units was their different scope on focus and outreach. Established as the regional unit of the IPC-TW, the Scandinavian Secretariat was obliged to monitor and prepare material for all revolutionary opposition groups within land and maritime transport workers' union. The Copenhagen Port Bureau, in contrast, focussed only on agitation and propaganda among foreign mariners as well as directed its activities towards the local waterfront.

219 Vernon L. Pedersen, "George Mink, the Marine Workers Industrial Union, and the Comintern in America," Labor History 41, no. 3 (2000): 308-309.

220 "International Seamen's Club," Labor Unity 1, no. 7 (1.4.1927): 8.

221 George Mink, "The Seamen's Clubs and the M.W.P.L.," Labor Unity 2, no. 10 (November 1928): 16-17. Mink was not anymore residing in the USA when Labor Unity published his article. His activities in New York were cut short as he enlisted on a Us merchant vessel that sailed for the Soviet Union in spring 1927. Arriving at the Black Sea port Novorossiysk, he did not return with the freighter but travelled to Moscow where he attended the RILU World Congress and the Fifth IPC-Tw conference in April 1928. See Pedersen, "George Mink," 310.

222 "Theses of Report on Activities of IPCAA of Transport Workers, Report by Comrade Achkanov," presented at meeting of the Executive Bureau of the RILU, 8.1.1929, 534/5/207, 17, RGASPI. 
The Scandinavian Secretariat was established in the aftermath of a regional conference held in Gothenburg in February 1925. Regional cooperation between the left-wing/communist fractions within the national transport workers' unions had been non-existent prior to the Gothenburg Conference. Neither the conference nor the activities of the Scandinavian Secretariat have left much documentation, apart from a short report written by its Norwegian secretary Leif Foss in April 1928. However, the report together with the correspondence between him and Sven Linderot provide a rough outline of its activities. Leif Olaf Foss (1899-1982) had been a sailor until 1919 when he started work as a dockworker. He was a member of Norsk Matros og fyrbøterunion as well as Dokkearbeidernes forening, the Norwegian harbour workers' association, which he headed from 1921 to 1925 . Foss belonged to the radical left and joined the Norwegian Communist Party, Norges Kommunistiske Parti (NKP, established in 1923). In 1925, he became a member of the direction of Norsk Jern- og Metallarbeiderforbund, the Norwegian metal workers' union. Apart from running the Scandinavian Secretariat, Foss was also NKP secretary for trade union work. Sven Linderot (1889-1956), in turn, belonged to the inner circle of the Swedish Communist Party, Sveriges Kommunistiska Parti Sektion av Komintern (SKP), and acted as party secretary for trade union work during the latter half of the 1920s. ${ }^{223}$

Communist agitation among the trade unions and their national federations in the Nordic countries had seen several vicissitudes during the 1920s. In Norway, where communist activity was legal, the central organisation of trade unions initially decided to join the RILU but eventually voted for neither joining the RILU or the IFTU. In Sweden and Denmark, the central organisations were members of the IFTU. In Finland, where the communist party was illegal since 1918, the left-wing dominated the Finnish central organisation of trade unions but had also decided to stay outside the internationals. The formation of the Anglo-Russian Joint Advisory Council in 1925 raised hopes in the Finnish and Norwegian trade union movements for creating a united trade union international. After the collapse of the Anglo-Russian negotiations at the end of 1926, the Russians started to discuss cooperation with the Nordic trade unions in early 1927, culminating in the formal agreement of Norwegian-RussianFinnish cooperation at a conference in Copenhagen in February 1928.224

223 See further Weiss, För kampen internationellt!, 88, 259.

224 Tauno Saarela, "Nordic Communism in the Communist International," in Regional Cooperation and International Organizations: The Nordic model in transnational perspective, eds. Norbert Götz and Heidi Haggrén (Abingdon, Oxon: Routledge, 20o9), 242; Tosstorff, "Moscow Versus Amsterdam," 87. 
United Front-tactics also framed the activities of the Scandinavian Secretariat. Its main field of activities was propagandistic and concentrated on the formation and strengthening of communist and left-wing fractions within the unions and national federations. However, the results had been disappointing, Foss noted, especially in Sweden where the left-wing and communist fractions had a weak position within the unions. Better results had been achieved in Norway where communist/left-wing fractions existed in all districts as well as in the leadership of the Transport Workers' Union, the Seamen's and Firemen's Union, the Railwaymen Union, and the Railway Functionaries' Union. The only exception was the Norwegian Locomotive Drivers' Union. Less promising was the situation among the Railway Workers' Union in Denmark where the communist/left-wing minority was not represented in the union's leadership. ${ }^{225}$

Similar to other regional IPC-TW bodies, the Scandinavian Secretariat concentrated its main energy on railway and other land-based transport worker unions. This is clearly reflected in the contents of Den Internasjonale Transportarbeider, the organ of the Scandinavian Secretariat (see Figure 6). Launched in June 1926, its monthly edition being initially as high as 6,000 copies but soon dropped to 3,400 copies. Officially claimed to the mouthpiece of the radical maritime and railway transport workers, it carried few articles concerning issues of seamen and harbour workers. ${ }^{226}$ In addition, the mimeographed publications of local sections of opposition groups correlated with the operational basis of the Scandinavian Secretariat. All but one were published by minority groups in Norway: Huk'en by the harbour workers in Oslo, Sporvekslen for the railway workers in Oslo, Signalet by the railway functionaries in Hedemark, Signal by the railway functionaries in Trøndelag, Verkstedsarbeideren by the railway functionaries in Drammen, and Transportproletaren by the local opposition group of harbour workers and seamen in Bergen. Most of these publications were occasional and were issued in small editions, in total about 6 to 8,ooo copies. The exception was the publication of the Copenhagen Interclub, Lanternen, as will be discussed below. ${ }^{227}$

Nevertheless, some positive notes were received from the waterfront in Denmark. Although communists and radical left-wing influence among the Danish Seamen's Union was less profound and organised groups were small, the situation was markedly different in other maritime unions. The

225 Leif Foss, IPKs arbeide i Skandinavien februar 1925 - februar 1928. En kortfattet oversikt, dated Moscow 2.4.1928, 534/5/19o, 46-47, RGASPI. Hereafter: Foss, IPK s arbeide i Skandinavien.

226 Foss, IPK s arbeide i Skandinavien, 48.

227 Foss, IPK s arbeide i Skandinavien, 49. 


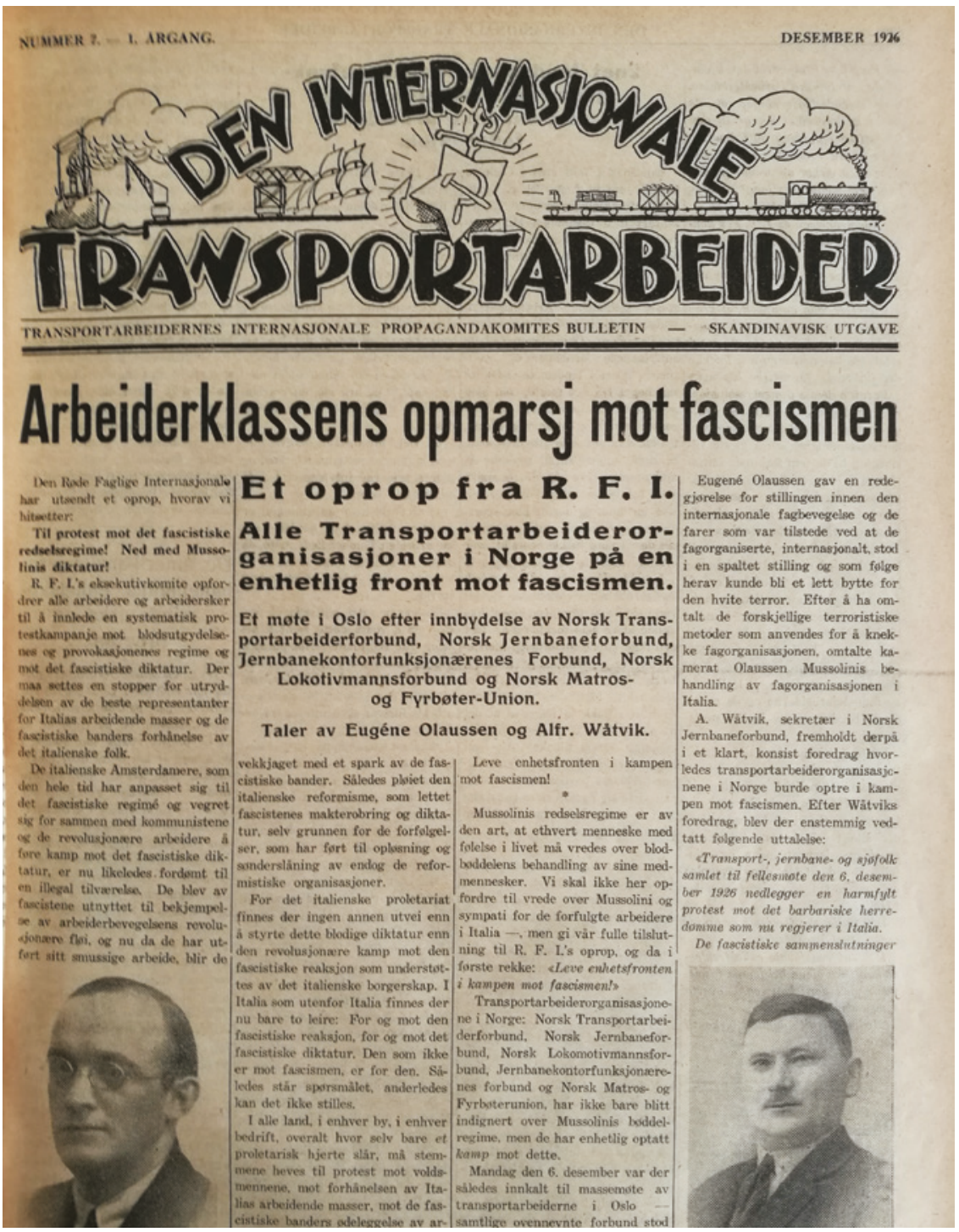

FIGURE 6 Den Internasjonale Transportarbeider, journal published by the Scandinavian Secretariat of the International Propaganda Committee of Transport Workers.

radical opposition within the Danish union for transport and harbour workers (Transport- og havnearbeiderne i Danmark) had organised an 80-person strong minority group in Copenhagen in addition to smaller communist fractions and minority groups in several other Danish ports. Most promising, however, was the situation among the Danish Stokers' Union (Søfyrbødernes forbund) where 
the communists controlled its section in Copenhagen, held strong positions in the other sections and listed three out of seven members among the union's leadership. ${ }^{228}$

The dominant position of the communists among the harbour workers and stokers in Copenhagen was largely the achievement of Richard Jensen (1894-1974), the founder of the Copenhagen Port Bureau and Interclub. Jensen had been a stoker before the war and cooperated with the syndicalist agitator Thøger Thøgersen. Jensen joined the syndicalist opposition already in 1916 and engaged in the Danish Stokers' Union, which he headed in 1919-20. Thøgersen had at this point emerged as the key driving force for the unification of the radical Left, resulting in the establishment of the Danish Communist Party (DKP) in 1921. Jensen joined the party in the same year and became a close aide to Thøgersen who sent him on several missions to Moscow. ${ }^{229}$

Jensen gained a strong position in the DKP as well as within the Comintern and RILU-apparatus during the 1920s. He was head of the party's cell or section for maritime workers in Copenhagen, which, in turn, dominated the maritime unions, and, ultimately, the port of Copenhagen. His official position with the RILU and IPC-TW is not known although as head of operations in Copenhagen, he was subordinated to the IPC-TW Scandinavian Secretariat. Moreover, his role as courier and facilitator of special missions was of equal importance. Documentation for his clandestine operations is patchy. As early as 1919, he seems to have received funds from Moscow. ${ }^{230}$

Jensen's position as key facilitator of the IPC-TW commenced after the foundation of the DKP-maritime section in 1925. This move had been instigated by the RILU and IPC-TW who had instructed the parties to establish special units to support the activities of the radical/communist minorities within the maritime transport workers' unions. ${ }^{231}$ Jensen received 5,367 Danish crowns (D KK) from RILU-funds to cover his expenses in 1925, of which he used 1,115 DKK for "agitation."232 Jensen's next step was the established of a Port Bureau and Interclub in Copenhagen in March 1926. The first mission of the Copenhagen Interclub was the launching of its own organ, Lanternen, published monthly in

\footnotetext{
228 Foss, IPK s arbeide i Skandinavien, 48.

229 See further Erik Nørgaard, RichardJensen - historien om en mand (Copenhagen: Holkenfelt, second revised edition 2007).

230 Erik Nørgaard, Drømmen om verdensrevolutionen: Komintern og de revolutioncere søfolk (Lynge: Bogan, 1985), 88-95.

231 Christian Tortzen, En sømand han maa lide: Sømcendenes Forbund 1897-1997 (Copenhagen: Forlaget Pantheon og Sømændenes Forbund i Danmark, 2001), 224.

232 Richard Jensen, Regnskab for 1925, 534/5/184, 3, RGASPI.
} 


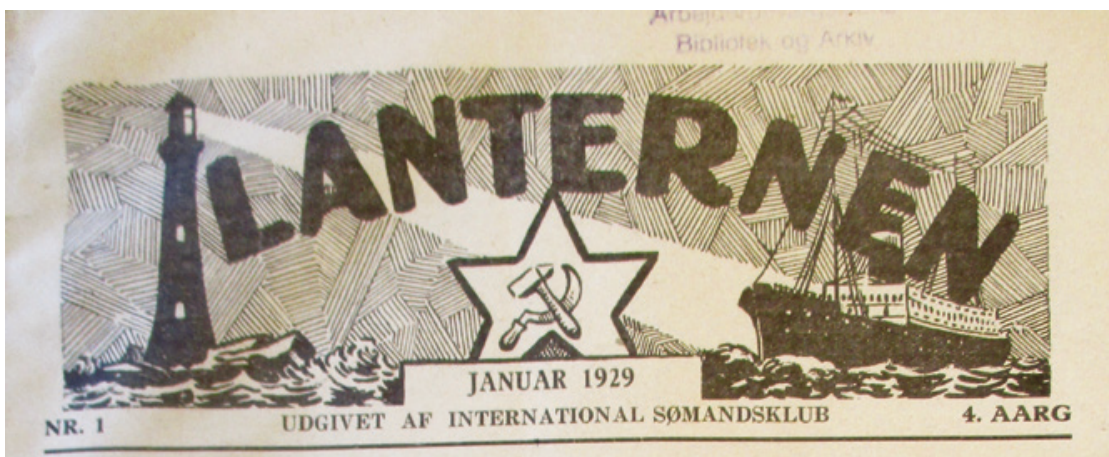

\section{Den skandinavisk-russiske Somandskonference.}

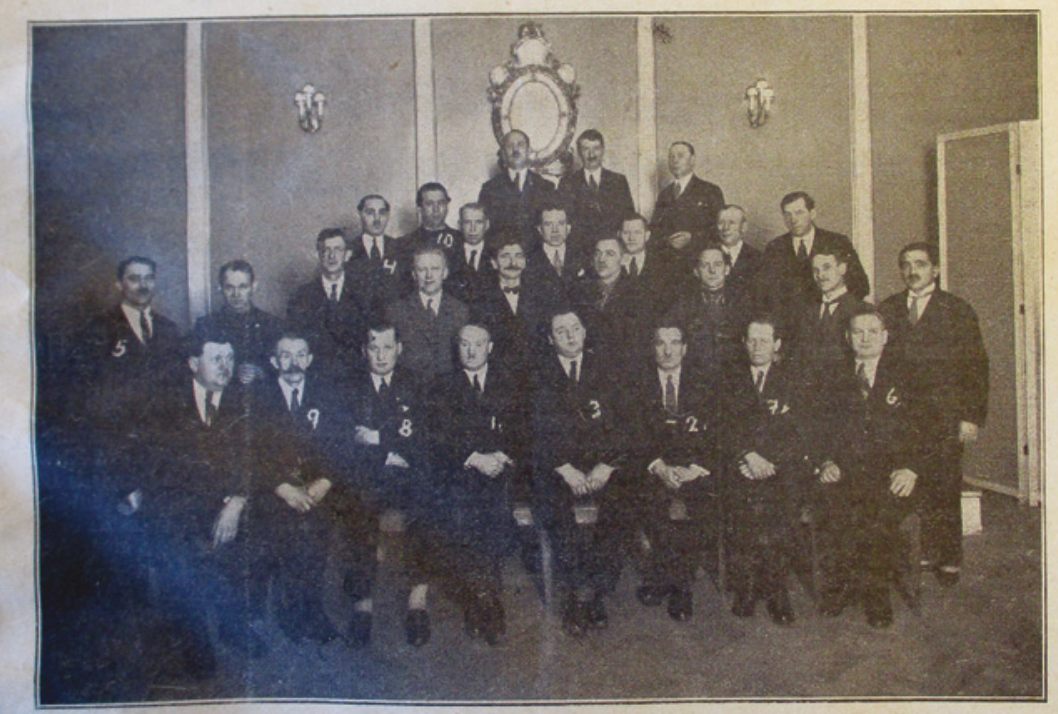

Pas Billedet res:

ge. 9. Mikkelsen, Norge, 10 Rich. Jen- Kobenhavn hvor der opnaaedes Enig-

1. Rusland: Bystroff. 2. Rusland: sen, Danmark. hed om et Forslag til Samarbejde, der Krukloff. : Birkeland, Norge, 4 . Erik

Jacobsen, Danmark. 5. Peter Bach, nu er til Ratificering i de respektive - Som vi forlenten medielte afholdtes Organisationer.

stermann, Sverrig. 8. Didriksen, Nor- $\mid \begin{aligned} & \text { dinavisk-russisk Somandskonference i ferencens Deltagere. } \\ & \text { finger }\end{aligned}$

FIGURE 7 Lanternen, journal published by the Copenhagen Interclub. The front page of Lanternen 4, no 1 (January 1929) carries a photograph showing the participants at the conference of Scandinavian and Russian maritime transport workers, held in Copenhagen in December 1928. 
TABLE 5 Expenses of the Interclub in Copenhagen, 1926-1928 (Danish crowns, DKK)

\begin{tabular}{llllllllllllll}
$\begin{array}{l}\text { Month/ Jan } \\
\text { Year }\end{array}$ & Feb & Mar Apr & May Jun & Jul Aug & Sep Oct Nov Dec \\
\hline 1926 & {$[\ldots]$} & 604 & 692 & 844 & 723 & 631 & 684 & 548 & {$[\ldots]$} & 530 & 673 & 706 \\
1927 & 617 & 579 & {$[\ldots]$} & 490 & 565 & 533 & 467 & 502 & 620 & 517 & 540 & 575 \\
1928 & 617 & 597 & 573 & 573 & 573 & 9,661 & 188 & 188 & 183 & 276 & 276 & 276
\end{tabular}

SOURCE: (1926) RICHARD JENSEN, REGNSKAB FOR JANUAR ... DECEMBER 1926, 534/5/184, RGASPI; (1927) INTERKLUB KØBENHAVN, REGNSKAB FOR JANUAR ... DECEMBER 1927, 534/ 5/189, RGASPI; (1928) INTERKLUB KøBENHAVN, REGNSKAB FOR JANUAR ... SEPTEMBER 1928, 534/5/202, RGASPI, AND RICHARD JENSEN, REGNSKAB FRA MARTS 1928 TIL 31/3 1929, NO DATE [1929], 534/5/211, 10, RGASPI

2,300 copies (see Figure 7). ${ }^{233}$ Not surprisingly, Jensen's expenses increased, see Table 5. Although the accounts for 1926 to 1927 do not reveal how much was sent to Copenhagen, Jensen's reporting of his accounts for March to December 1928 reveals that he had received 13,736 DDK from the IPC-TW Berlin Bureau. This sum more or less covered the costs for running the Interclub as well as publication and travel expenses. ${ }^{234}$

British intelligence was certainly right when it assumed that Moscow had paid of the activities of the Copenhagen Port Bureau. According to their informants, Jensen had received 20,000 DKK in 1926 to pay for his activities in Denmark while he at the same time had expenses amounting to 100,000 DKK. ${ }^{235}$ Another British report stated that he had received 1,200 British pounds for running the Copenhagen Interclub in 1927.236

The Copenhagen Port Bureau and Interclub had a limited target group in comparison to the 'world ports' of Hamburg or Rotterdam. The port of Copenhagen was a regional hub, linking the Baltic with the North Sea. British, Finnish, German, Norwegian and Swedish vessels frequently called at the port; Southern European or even non-European mariners rarely sojourned

233 Foss, IPK s arbeide i Skandinavien: 49; Oplysninger vedrørende kommunistisk propaganda (april 1926), Stockholmspolisens kriminalavdelning Rotel 6 med föregångare, F X:8 Utländska kommunistiska handlingar, sNA.

234 Richard Jensen, Regnskab for Marts-September Maande 1928, 534/5/202, 5-6, RGASPI.

235 Extract from letter to Cuthbert Laws Esq., The Shipping Federation, 52, Leadenhall Street, E.C.3., dated 25.7.27, Richard Jensen personal file, KV2/2158, TNA.

236 Extract of report, dated 3.11.27, Richard Jensen personal file, KV2/2158, TNA. 
in Copenhagen. On the other hand, Copenhagen was the node of the Danish shipping industry. 237

The first location of the Copenhagen Port Bureau was at 15, Toldbodgade in the Nyhavn district. The Interclub was open every evening from seven to 11 pm; special thematic lectures were organised on Wednesdays, and the reading room was stuffed with newspapers, magazines and socialist literature in Scandinavian languages. ${ }^{238}$ Soon activities expanded and the Interclub organised mass meetings and musical evenings twice a week; on average 1,0oo foreign and Danish mariners visited its premises in $1926 .{ }^{239}$ Further progress was reported by Jensen in 1927: The Interclub listed 8,76o visitors of which 6o percent were Danes and it had managed to organise the left-wing opposition within the Seamen's Union (62 members) and the Stokers' Union (138 members). ${ }^{240}$ Nevertheless, the premises at Toldbodgade were soon cramped and Jensen moved the Port Bureau to larger offices at 53, Havnegade in May 1928. ${ }^{241}$ The Port Bureau rented two floors in the building. The Interclub operated a restaurant in the basement and a café, a library, a reading hall in addition to a writing hall on the first floor (see Figure 8). In addition, the Interclub managed a spacious cloakroom where visiting seamen could leave their belongings. ${ }^{242}$

The paucity of communication between Oslo and Copenhagen restricted the operational capacity of the Copenhagen Port Bureau. Directives and instructions sent from Oslo were usually one to two months late. Jensen was at times at loss and had to make his own decisions, especially when he was arranging for illegal transport of couriers and dispatches. Such circumstances were to cause frictions between the two units, and Jensen asked Foss to come to Copenhagen for a meeting late $1927 \cdot \cdot^{243}$

\subsection{The Radical Spaces of the Interclubs}

The rationale of a Port Bureau and its Interclub was their legal status. Outside Soviet Russia, they could only be established in a location if communist activity had not been banned and declared illegal by the national authorities. Consequently, a bureau that was constantly raided by the police or closed

\footnotetext{
237 Atschkanow, Bericht des I.P.K.T. über die Hafenbüros, 1.12.1926, 534/5/178, 61, RGASPI.

238 "Klubben," Lanternen 2, no. 7 (July 1927): 4.

239 Atschkanow, Bericht des I.P.K.T. über die Hafenbüros, 1.12.1926, 534/5/178, 61, RGASPI.

240 Richard Jensen, Regnskab fra Marts 1928 til 31/3 1929, no date [1929], 534/5/211, 10-11, RGASPI.

241 Richard Jensen to 'IPK', Copenhangen 1.4.1929, 534/5/211, 14, RGASPI.

242 "Nye Klub-Lokaler," Lanternen 3, no. 4-5 (May 1928): 3.

243 Richard Jensen, Beretning for August \& September Maaned, København 10.10.1927, 534/5/ 189, 13, RGASPI.
} 


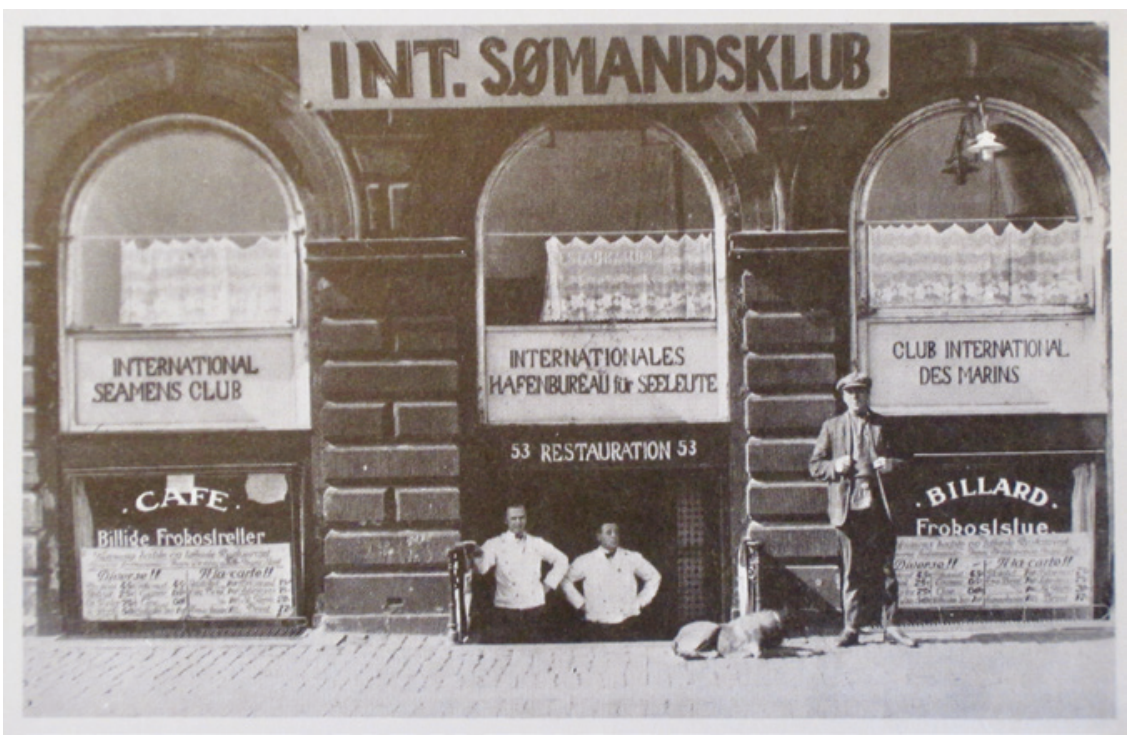

FIGURE 8 The Copenhagen Interclub, located at 53, Havnegade. The person standing in front of the building is Richard Jensen. Source: 107 Richard Jensen Arkiv, Danish Labour Movement Library and Archives.

by the local authorities was of little value. According to a report sent to the Swedish Secret Service, the Port Bureaus and Interclubs had three main missions: To agitate among seamen, to disseminate illegal communist literature, and to provide a safe space for the gatherings of the international propaganda committees. ${ }^{244}$ Their task was to combat the 'false' message of the Christian seamen's missions and 'reformist' leadership of the maritime unions as well as to support the maritime workers in their struggle for better working conditions and salaries. ${ }^{245}$ Their objectives were publicised in magazines and leaflets and were thus known for both the target groups as well as the authorities. For example, the Copenhagen Interclub published regularly advertisements in its magazine, calling class-conscious seamen to visit the Interclub instead of the Christian seamen's missions. ${ }^{246}$ The New York Interclub, in turn, was

244 Internationella hamnbyråer, 1.11.1928, UD:s arkiv 1920 års dossiersystem, HP 1459 32D, Den bolsjevikiska rörelsen: Sverige och utlandet, 1927-1928, sNA. A copy of the German report, dated 15 October 1927, is filed in R1507/2035 Reichskommisariat für die Überwachung der öffentlichen Ordnung und Nachrichtensammelstelle im Reichsministerium des Inneren, BarchB.

245 "Hampurin merimiesklubi 10-vuotias", Majakka 6 (1932): 21.

246 Lanternen 2:6 (1927). 
strategically located close to the Seamen's Church Institute. ${ }^{247}$ Leaflets distributed in the latter premises invited the seamen to visit the Interclub: "DONT [SIC] EAT IN DIRTY STEW POT JOINTS / THE GRUB IS BAD ENOUGH ABOARD SHIP / TRY THE CLEANIEST PLACE ON SOUTH ST. INTERNATIONAL SEAMEN'S CLUB RESTAURANT." 248

Naval mariners and visiting war vessels were special targets of agitation. Leaflets and brochures printed by the Interclubs were smuggled on board men-of-wars. "Use every opportunity to carry our propaganda among the blue jackets," urged Achkanov in his correspondence. Top security was the order of the day - appeals should never be issued in the name of the Interclub. ${ }^{249}$ Other activities were always public manifestations in every port where communist actities were legal - participation in demonstrations with banners and slogans printed or painted on banderoles, organisation of mass meetings at the Interclub with open invitations to everyone who was interested to participate.

Government authorites, the labour unions as well as the shipowners and Christian seamen's missions, in turn, denounced the Interclubs as dangerous agitation nests where seafarers were radicalised and lured them to adopt the communist credo. Press cuttings collected by the German police witness about the fear of these radical establishments or 'free spaces' which neither the authories, the union leadership or the Christian mission were able to control. The Catholic newspaper Germania warned its readers that the Interclubs were perilous sites where seamen were radicalised and revolutionised; ${ }^{250}$ the IWW magazine Marine Worker branded them as "scratch-a-way-Inn" that were used by the communists to "lure penniless seamen, especially in the winter months, to come in and partake of watery stew and political propaganda."251 The Australian government authorities as well as the Seamen's Union of Australia viewed the Interclubs with suspicion and regarded them to be nothing else as clandestine agitation centres of the RILU: "The Club in Sydney was full of Communist literature and prominence is given to a photograph of Lenin." ${ }^{252}$ In the USA, the Seamen's Journal warned its readership that the only task of

247 Stephen Schwartz, Brotherhood of the Sea: A History of the Sailors' Union of the Pacific, 1885-1985 (New Brunswick, NJ: Transaction Books, 1986), 70.

248 Seamen's Church Institute, "Hospital Flyer," SCI Digital Archives, http://seamenschurcharchives.org/sci/items/show/1828, accessed November 23, 2015 .

249 Achkanov to "Dear Comrades," Moscow 30.6.1927, 534/5/186, 57, RGASPI.

250 "Sowjetpropaganda auf dem Seewege", Germania Nr 5, 7.1.1931.

251 Marine Worker, 15.10.1928, quoted in Schwartz, Brotherhood of the Sea, 71.

252 Canberra Times, 3.5.1928. 
the Interclubs was "to make use of the world's seamen as the shock troops for Communism."253

The core unit for communist agitation and propaganda among maritime transport workers was the revolutionary nucleus or cell. Following a RILU-resolution on the organisation of land-based trade union work in 1924, the communist parties started to establish so-called sea cells. Members of the sea cells were party-members of a local branch of the seamen's and/or stokers' unions; members of the sea cell constituted the communist fraction within the revolutionary opposition in the local branch of a trade union. The sea cell was active in those harbours where its members were residing or living when they were not at sea, i.e., either waiting for a job or being unemployed. The main task of the sea cell was the publication of a handwritten stencil, sometimes a mimeographed seamen's journal. Another important objective was to summon and organise jobless seamen in association with the party's local committee for work among the unemployed,. ${ }^{254}$

Communist agitation among maritime transport workers was land-based until the mid-192os. Their activities on board the merchant ships remained unorganised although individual crews might set up a ship committee or ship council. This unit was a novel institution during the 1920s. The ITF had pushed for the institutionalisation of ship councils by the International Labour Organization in 1924. The general idea was to constitute a body for the intervention of the crews in the following questions: 1) abandoning of vessel in case of shipwreck, 2) testing of seaworthiness of the vessel, 3) control of food supplies on board, 4) reduction in grade of seamen, 5) dismissal for insubordination, and 6) searching of a seaman's kit. According to the ITF proposal, the ship council was to be composed of one representative of the officers, one of the deck hands and one of the engine room hands on vessels numbering a crew of seven or more members. The composition of

253 Seamen's Journal, September 1928, quoted in Bruce Nelson, Workers on the Waterfront. Seamen, Longshoremen, and Unionism in the 1930 (Urbana and Chicago: University of Illinois Press 199o [1988]), 76.

254 "Die organisatorischen Richtlinien zum Aufbau von Schiffs- u, Bordzellen," in Max Barek, Jahresbericht der Zelle Schiffahrt Hamburg, Jahr 1928, Internat. Hafenbüro für Seeleute Hamburg, RY 1/I 2/708/54, 95, BArchB-SAPMO. 
a ship council on vessels with a crew of less than seven members would be smaller. ${ }^{255}$

The RILU and the IPC-TW did not in principle object the proposal of the ITF on the formation of ship councils. However, as will be outlined below, their drive establishing ship cells on board vessels aimed for the politicisation of the ships councils and, ultimately, to take control of them. The main argument of the communists was that the ship's councils were not "democratic" bodies as they only represented members of trade unions. The communists therefore demanded that the ship committees were to include all members of a crew, including those who were not union members. Besides, the ship committees were to nominate a leading group that was to plead the cause of the crew and its individual members in meetings with the officers. Not surprisingly, the reformist leadership of the national maritime trade unions as well as the shipping industry rejected this idea, as it would have opened the door for a radicalisation of the crews. Nevertheless, the push for the establishment of ship committees became an integral part of the communist attack on the ITF and the reformist leadership of the national maritime unions and added to the friction within the unions.

The initial attempt to organise communist seamen within the sea cells of the party proved soon inefficient. The main flaw was the incapacity to reach out to seamen on their place of work, namely the ship. This, however, had been a fundamental cornerstone in communist trade union strategies that impelled the communists to form nuclei in the workshops and factories. This policy was effective for land-based members and created communist spaces at the workplaces and in residential areas. For example, in some of the working-class areas of Hamburg, such as the Gängeviertel of Hamburg Neustadt or those in Barmbek or Schiffbek, the Communists dominated the local political space and were able to create 'free-zones' controlled by the party and its organisations. ${ }^{256}$

255 "Resolution on Ship's Councils, submitted by the International Seamen's Conference meeting in Hamburg on 4,5 and 10 August to the International Labour Office," in Report on the International Congress held from 7 to 12 August 1924, 149-150.

256 Elisabeth Pape and Leonie Barghorn, "Klein Moskau wurde die Gegend genannt" Nachbarschaft und Politik im Hamburger Gängeviertel," available at asg-hh.de/download. html?\&filename=g_ngeviertel ... pdf, checked 20.8.2017. A detailed description of communist organisation of local space and time is presented in two studies on the Hamburg waterfront, see Klaus Weinhauer, Alltag und Arbeitskampf im Hamburger Hafen:Sozialgeschichte der Hamburger Hafenarbeiter 1914-1933 (Paderborn, München, Wien, Zürich: Schönigh, 1994), and Eiber, Arbeiter und Arbeiterbewegung in der Hansestadt Hamburg. For a general description of communist organisation of time and space in Weimar Germany, see Klaus Mallmann, Kommunisten in der Weimarer Republik. Sozialgeschichte einer revolutionären Bewegung (Darmstadt: Wissenschaftliche Buchgesellschaft, 1996). 
Depicted as 'Little Moscows' and known for their 'small-place communism and counter-communities', they existed in several locations in inter-war Western Europe. ${ }^{257}$

The solution for organising party members on ships was the ship cell or revolutionary nucleus on board a vessel. The RILU and IPC-TW launched new strategy in 1926, and Achkanov ordered all Port Bureaus and revolutionary groups of maritime workers to implement it immediately. 258 The RILU, too, sent a circular letter about the new strategy to the communist parties in Australia, Belgium, Britain, Denmark, France, Germany, Greece, Italy, Norway, South Africa, Spain, Sweden and the USA. ${ }^{259}$ Following the new strategy, all party-members of a ships' crew were urged to form a nucleus or ship cell as soon as a vessel had left the harbour. Once the ship cell had been established, its members were to nominate its leader. Next, the ship cell was to press for the formation of a ship committee and get its member elected into the leadership of the ship committee. The land-borne sea cells as well as the Port Bureaus, in turn, were to get in contact with the ship cells, and to provide them with literature and propaganda material to be distributed among the crew members as well as to get feedback and testimonies to be used and published in the sea cell's publications, see Figure $9 .{ }^{260}$

The Port Bureaus and Interclubs constituted the nodes in the new strategy. Apart from serving as extra-territorial centres for national revolutionary minority groups, their new task was to convince visiting crews to form ship cells and ship committees on board their vessels. Once a ship cell had been formed and the vessel visited a harbour with a Port Bureau, its leader was to inform the officials of the Port Bureau about its existence. ${ }^{261}$ Ideally, the Port Bureau notified the other Port Bureaus as well as the local sea cells in the home destination of the crew about the existence of a new ship cell. Together, the three units, the Port Bureaus, the sea cell ashore and the ship cell on board,

257 Ad Knotter, “'Little Moscows' in Western Europe:The Ecology of Small-Place Communism,” International Review of Social History 56, no. 3 (2011): 475-510; Kevin Morgan, "Bastions, black spots and other variations in and beyond the specificities of the Little Moscow," Twentieth Century Communism 5, no. 5 (2013): 193-209.

258 Achkanov, To all Port Bureaus and Revolutionary Seamen's groups of all countries [ca. 1926], 534/5/177, 14-15, RGASPI.

259 RILU Org. Department, Circular letter, [ca. 1926], 534/5/177, 16-18, RGASPI.

26o "Die organisatorischen Richtlinien zum Aufbau von Schiffs- u, Bordzellen," in Max Barek, Jahresbericht der Zelle Schiffahrt Hamburg, Jahr 1928, Internat. Hafenbüro für Seeleute Hamburg, RY 1/I 2/708/54, 95, BArchB-SAPMO.

261 Reports on the formation of sea cells are scattered in the archival deposits of Soviet Port Bureaux but I have not been able to conduct a systematic assessment of the files. 


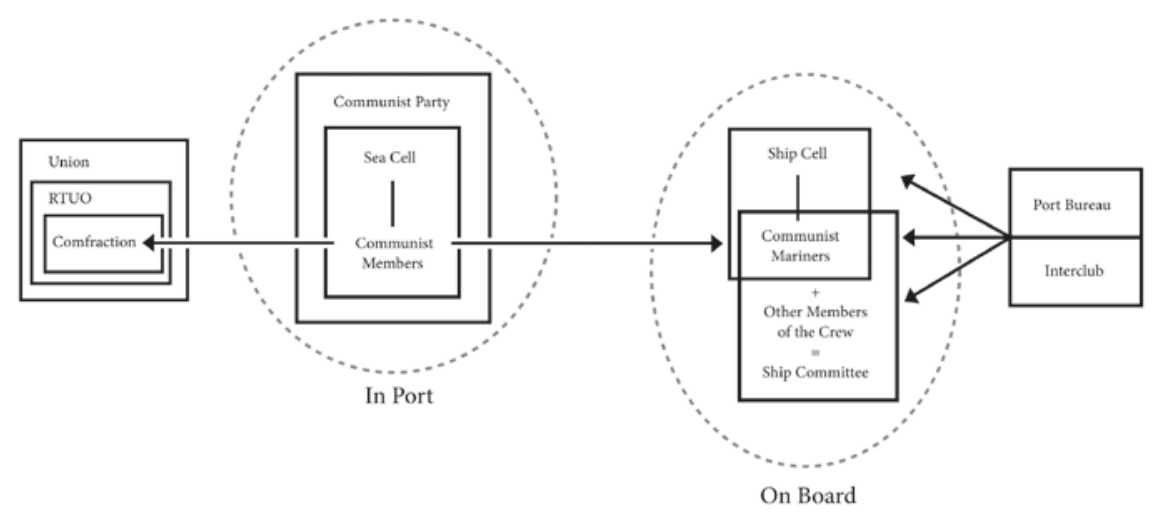

FIGURE 9 The sea cell, the ship cell and the ship committee.

constituted the global communications network of the IPC-TW, the RILU and the Comintern. In practice, the establishment of 'thick' transnational connections proved difficult to achieve as the horizontal links between the Port Bureaus were rudimentary at best during the 1920s. Besides, the extension of a transnational network depended on the lifespan of a ship cell, as it only existed when its members were part of a crew. Once a vessel returned to its port of origin, the crew usually signed off and the ship cell was disbanded. ${ }^{262}$

\subsection{Establishing a Global Communication Network: The Hamburg Method}

Achkanov's instructions for the new strategy reached the Port Bureaus outside Soviet Russia in March 1926. However, its implementation was rather uneven. While the Bordeaux Port Bureau only managed to establish about six ship cells on board French vessels, the Rotterdam Port Bureau reported the formation of 41 ship cells by the end of October 1926. Most successful, however, had Albert Walter been in Hamburg where the Port Bureau had contact with 84 ship cells. ${ }^{263}$

Walter managed to establish a global communication network one year later. During the last quarter of 1927, the Hamburg sea cell (Seezelle Hamburg, sometimes also termed as Zelle Schiffahrt Hamburg) listed 103 members on board 85 German merchant vessels travelling to various ports in North and

262 Die organisatorischen Richtlinien zum Aufbau von Schiffs- u, Bordzellen, enclosed in Max Barek, Jahresbericht der Zelle Schiffahrt Hamburg, Jahr 1928, Internat. Hafenbüro für Seeleute Hamburg, RY 1/I 2/708/54, 95, BArchB-SAPMO.

263 Atschkanow, Bericht des I.P.K.T. über die Hafenbüros, 1.12.1926, 534/5/178, 61-63, RGASPI. 
South America, Africa, Asia and Australia. ${ }^{264}$ The Copenhagen Port Bureau, too, registered a take-off; its Interclub listed 400 members of which 200 were members of the DKP sea cell. ${ }^{265}$ Soon, however, bad news were pouring in at the IPC-TW headquarters. Activities in Copenhagen had stagnated (see below), while those in France had more or less collapsed. "In France little attention is paid to the question of organising transport workers, and especially seamen. No revolutionary nuclei are formed on the vessels," Achkanov critically noted. ${ }^{266}$ Even more alarming was the situation in Britain, and Achkanov accused the Minority Movement for deliberately obstructing orders from Moscow: "They organise no revolutionary nuclei on board ships."267

The only positive development was the Seezelle Hamburg which counted 270 members at the end of 1928 (see Table 6). In addition, Samsing had managed to establish a Norwegian sea cell in Hamburg, listning 25 members at the end of the year. ${ }^{268}$ Nevertheless, Walter's world-wide network was not without flaws as about 40 percent of the members of the Seezelle Hamburg were either jobless, out of reach for the sea cell ("auf wilder Fahrt"; i.e., on unknown destinations) or had not reported to the sea cell after signing off from the ship. ${ }^{269}$ Still, this did not retard the extension of his operations; in June 1929, the Seezelle Hamburg numbered already 358 members, and increased to 512 members by the end of the year. ${ }^{270}$

Activities in Germany seemed to boom as the comrades at the Hamburg Port Bureau managed to start actities in Bremen. A sea cell was formed in Bremen in March 1927, seven months later it had established a reading room, was running an Interclub at 111, Lloydstrasse, and had started to publish its own journal, Der Scheinwerfer (although very irregularly; in 1928, only one number had been printed). The Bremen Interclub emerged soon as a hub for local seamen; in 1928, it reported an average of $35^{\circ}$ visitors per month and was in contact with five ship cells. ${ }^{271}$

264 Information provided in map about destinations of Zelle Schiffahrt Hamburg, 534/5/194, 212, RGASPI.

265 Richard Jensen, Beretning for Aaret 1927, København 1.12.1927, 534/5/189, 16-17, RGASPI.

266 Theses of Report on Activities of IPCAA of Transport Workers, Report by Comrade Achkanov, presented at meeting of the Executive Bureau of the RILU, 8.1.1929, 534/5/207, 17, RGASPI.

267 Theses of Report on Activities of IPCAA of Transport Workers, Report by Comrade Achkanov, presented at meeting of the Executive Bureau of the RILU, 8.1.1929, 534/5/207, 17, RGASPI.

268 Internationales Hafenbüro Hamburg, Jahresbericht 1928, 534/5/210, 3, RGASPI.

269 Mitgliedsstand der Zelle Schiffahrt Hamburg im Jahre 1928, Internat. Hafenbüro für Seeleute Hamburg, RY 1/I 2/708/54, 96-98, BArchB-SAPMO.

270 Internationales Hafenbüro Hamburg, Bericht Juni 1929, 534/5/210, 67, RGASPI; Internationales Hafenbüro Hamburg, Jahresbericht 1929, 534/5/210, 107, RGASPI.

271 Jahresbericht der Schiffahrtszelle Bremen für das Jahr 1928, 534/5/201, 92-95, RGASPI. 
TABLE 6 Zelle Schiffahrt Hamburg, members and vessles with ship cells, situation 1.1.1929; numbers given in bracklets are from Walter's report to Achkanov

Ship route (from Hamburg to $\mathrm{NN}$ )

Members Number

of

vessels

North America East Coast (New York, Philadelphia, 17

Baltimore, Boston, etc.)

North America West Coast (San Francisco, Portland, 5

Seattle, etc.)

Central America and Caribbean (Puerto Rico,

Havana, Vera Cruz, etc.)

South America East Coast (Rio de Janeiro,

Montevideo, Buenos Aires, etc.)

South America West Coast (Columbia, Ecuador, Peru 9 och Chile)

West, South and East Africa (Dakar, Cape Town, 10

Mombasa)

Australia and New Zealand (Melbourne, Sydney, 4

Newcastle, Adelaide)

East Asia (China, Japan)

Mediterrannean Sea and Black Sea

$\begin{array}{ll}15 & 12 \\ 26 & 22 \\ 20 & 16 \\ & \\ 40 & 31 \\ 18(16) & 7 \\ & \\ 40(44) & \\ 30 & \\ 268(272) & \end{array}$

North Sea, Baltic Sea (Netherlands, France,

Scandinavia, Finland, Soviet Russia)

Unknown destination ("Auf wilder Fahrt")

German deep-sea fishing fleet (White Sea,

Greenland, North Sea)

Unknown whereabouts or not reported

On land

$268(272)$

SOURCE: MITGLIEDSSTAND DER ZELLE SCHIFFAHRT HAMBURG IM JAHRE 1928, INTERNAT. HAFENBÜRO FÜR SEELEUTE HAMBURG, RY 1/I 2/708/54, 98, BARCHB-SAPMO; WALTER TO IPAC-TW SECRETARIAT, HAMBURG 25.2.1929, 534/5/210, 31, RGASPI

Walter's global communication network was an outcome of the so-called Hamburg method. The core idea was to establish personal contacts between an agitator and a seaman when a new ship arrived in Hamburg. A small group of Interclub functionaries and harbour activists visited the ship in order to distribute leaflets and pamphlets among the crew. Moreover, the crew members 
were invited to the club and participate in its evening programmes. Most importantly, a report was written after every visit, listing reliable contacts and identifying potential partners for future co-operation. The names of individuals, cells and ships were thereafter collected in a catalogue. Walter's database included hundreds of individual seamen and ships, and constituted the core of his communications network. ${ }^{272}$

Walter claimed the Hamburg Method to be the key to his success. In his mind, all the other revolutionary trade union opposition groups should elaborate their work among seamen in similar ways. The revolutionary nucleus constituted the core unit in his strategic considerations. The formation of a sea cell was time-consuming, Walter reminded, and should not be restricted to the premises of the Interclubs but must involve daily visits to the docks and ships mooring in the harbour. Once established, the sea cells and their member formed the basic unit of operations; they would carry out agitation on board, take command of strike committees, and compose the core of the revolutionary opposition within the trade unions. Of utmost importance was the publication of a journal for the sea cell as it was the visible (but mostly illegal) mounth-piece of the opposition. ${ }^{273}$

Apart from serving as vehicles for communist trade union agitation among crew members, trusted members of a ship cell handled the illegal transportation of printed agitation and propaganda material, the illegal transfer of cash subsidies to parties and unions as well as organised the hiding of stowaways, including couriers and emissaries. However, these operations were never organised by the IPCTW and RILU bureaus, and there are only a few hints about them in the monthly and annual reports of the Hamburg Port Bureau and Interclub. Clandestine operations, it seemes, were organised by another unit for which the Port Bureau functionaries and seamen served as mere transmitters. As Peter Huber and Niels Erik Rosenfeldt have emphasised, the core unit directing the Comintern's clandestine communications networks was its International Communications Office (OMs), among others its international courier service and the transfer of money to parties. ${ }^{274}$ Consequently, Walter's ships units were but cogs in a larger apparatus over which he and his bureau in Hamburg had no influence. Instead, the nodal point

272 Eiber, Arbeiter und Arbeiterbewegung, 186.

273 Internationales Hafenbüro Hamburg, Bericht Januar 1928, 534/5/201, 4, RGASPI.

274 Peter Huber, "The Cadre Department, the oms and the 'Dimitrov' and 'Manuil'sky' Secretariats during the Phase of Terror", in Centre and Periphery: The History of the Comintern in Light of New Documents, eds. Mikhail Narinsky and Jürgen Rojahn (Amsterdam: International Institute of Social History, 1996), 129; Niels Erik Rosenfeldt, The "Special" World. Stalin's Power Apparatus and the Soviet System's Secret Structures of Communication, I-II (Copenhagen: Museum Tusculanum Press, 2009). 
of the Comintern's clandestine communication network was the oms office in Berlin, headed by Max Ziese (at least) from 1929 to $193^{2} .{ }^{275}$

Still, Walter's cogs needed reliable "shop stewards" or ombudsmen (Vertrauensmänner) when they called at a port. A shop steward could be a functionary of a Port Bureau or Interclub, a member of a local sea cell or a revolutionary trade union opposition. In Albert Walter's mind, the most reliable were the members of a sea cell but he had to admit that such trusted agents existed in but a few places outside Germany. His communication network was therefore an unstable one, as was demonstrated in autumn 1928. Walter had received information from Australia about need for new propaganda material, he informed Moscow that he could arrange for its transport but needed a safe address for the delivery. ${ }^{276}$ Moscow replied that the material should be sent to the Interclub in Sydney but also notified him that they had no information about the unit or who was running it. ${ }^{277}$ Neither had Walter. A similar situation occurred in May 1929 when Walter was unable to organise the transfer of material to Egypt, Greece, Palestine and South Africa as he lacked secure adresses for delivery. ${ }^{278}$ The main reason for this, Walter stressed, was the poor performance if not neglect by the revolutionary trade union opposition groups of forming revolutionary nuclei outside Germany and the Scandinavian countries. ${ }^{279}$

\subsection{The Revolutionary Nucleus in Action}

The specific nature of maritime work posed operative challenges for the sea cells ashore. A mariner was out of its reach while working on board a ship and usually stayed at home only when searching for a new job or being unemployed. The average period for a German seaman to stay ashore was around four to six weeks in Hamburg. The Seezelle Hamburg tried to offset these restrictions by arranging study courses for the seamen at the Interclub. However, the organisation of political campaigns limited the amount of courses that were offered; in 1928 , for example, the functionaries were capable of arranging only a course on the topic "What are the communists calling for?" for twelve participants. More effective proved the political education organised by members of a the ship cells while they were at sea. ${ }^{280}$

275 Fowler, Japanese and Chinese Immigrant Activists, 88.

276 Internationales Hafenbüro Hamburg, Bericht August 1928, 534/5/201, 52, RGASPI.

277 NN to Walter, September 1928, 534/5/201, 56, RGASPI. The sender was perhaps Achkanov.

278 Internationales Hafenbüro Hamburg, Bericht Mai 1929, 534/5/210, 56, RGASPI.

279 Internationales Hafenbüro Hamburg, Bericht August 1929, 534/5/210, 84, RGASPI.

28 o Bericht über die Schulungsarbeit der Genossen in der Zelle Schiffahrt Hamburgs und den Bordzellen, Internat. Hafenbüro für Seeleute Hamburg, RY 1/I 2/708/54, 101, BArchB-SAPMO. 
Documentary sources about the activities of ship cells from the latter half of the 1920 are scanty. ${ }^{281}$ One of the few written testimonies is the activity report written by the ship cell on board the German steamer Gera from 1928. While moored in Antwerp, the members of the ship cell visited other vessels in the harbour area and distributed propaganda leaflets among their crews. While steaming towards South Africa, the Gera ship cell organised an evening event on the topic "Why is there an opposition in the unions" with ten crew members attending. A few days later, the ship cell organised a festive First of May-gathering on board; the event lasted for two hours and was attended by nine seamen, six stokers and one steward. The group started by singing the socialist anthem Brüder zur Sonne zur Freiheit, the German version of the Russian worker-song Brothers, towards the sun and freedom, followed by recitation of three German poems (Die Weber; Wahlesel; Die Ratten). The climax of the festivities was a speech on the theme "May First and its significance", followed by singing the International, playing the Red Guard March and reciting Karl Liebknecht's text Wir beugen uns nicht (We do not bend). The ship cell arranged two other discussion events for the crew before the steamer reached South Africa, the first about the relationship between the communist and social democratic party in Germany, the second about the conditions in the Soviet Union. On its arrival in East London, the ship cell visited British vessels and distributed English propaganda material among their crews. ${ }^{282}$

The Gera continued to Durban where it remained for a couple of weeks. During this period, the ship cell organised the commemoration of the Russian revolution with 21 persons participating, in addition to five meetings with lectures on the US American workers' movement as well as on pacifism and world peace, and training events for its participants in agitation and distribution of propaganda material. The Gera ship cell seems to have gained a remarkable position on board the steamer as it was able to furnish a "Red corner" and even manufacture its own flag. The peak of its activities was the solemn commenoration of those who had died during the revolution - the stem was decorated, the 45 participants sang the German version of the Russian Bolshevik dead march Вы жертвою пали (You fell victims), held speeches in honour of the fallen heroes, and went ashore to solemnely inaugurate the ship cell's

281 An account on the operations of a ship cell is provided by Hartmut Rübner, "Das Bordzellenbuch des Dampfers BOCKENHEIM," Archiv für die Geschichte des Widerstandes und der Arbeit 17 (2003): 131-150.

282 Bericht über die Schulungsarbeit der Genossen in der Zelle Schiffahrt Hamburgs und den Bordzellen, encosed in Max Barek, Jahresbericht der Zelle Schiffahrt Hamburg. Jahr 1928, Internat. Hafenbüro für Seeleute Hamburg, RY 1/I 2/708/54, 101, BArchB-SAPMO. 
flag. A few weeks later, the chip cell organised a joint meeting with their comrades on board the German steamer Urundi and marched together through the streets of East London singing the International. ${ }^{283}$ Unfortunately, the activity report stopped here. The ship returned to Germany and its crew signed off. This was also the end of the Gera ship cell. ${ }^{284}$

The example of the Gera ship cell was used by Walter to demonstrate the systematical application of the Hamburg Method. A ship cell was obliged to organise agitation and propaganda meetings each time when moored at a foreign port. The sea cell, in turn, was responsible for fostering the political awareness of its members. The input of the Interclub was of crucial importance; its task was to organise evening courses on trade union activism. ${ }^{285}$

Work of the sea cells was effective in places where a Port Bureau existed. However, as those units existed in but a few places outside Soviet Russia in the 1920s, the activities of the cells relied solely on the support of the local party. Most often, the party had a rather lukewarm attitude towards the sea cell. The situation in Kiel serves as an example. Here, the local party leadership had ordered the sea cell to place a party member on board every German ship that called at the harbour. This proved challenging, especially if no ship cell had been formed on board a vessel. The local police was well aware of the activities of the communists on the waterfront but had no clue who directed them. Most probably, they speculated, directives and funds had been sent from the Interclub in Leningrad. The local party itself, police sources assured, did not finance these activities and neither had the communists been able to infiltrate the local hiring offices. Rather, the sea cell's agitation was described as a mere nuisance and as clumsy attempts to place their propaganda material in the reading halls of the local seamen's house. ${ }^{286}$

283 Bericht über die Schulungsarbeit der Genossen in der Zelle Schiffahrt Hamburgs und den Bordzellen, Internat. Hafenbüro für Seeleute Hamburg, RY 1/I 2/708/54, 101, BArchB-SAPMO.

284 Internationales Hafenbüro Hamburg, Bericht November 1928, 534/5/201, 87, RGASPI.

285 Internationales Hafenbüro Hamburg, Bericht September 1928, 534/5/201, 58, RGASPI.

286 Regierungsrat Muttray, Betr. Den internationalen Seemannsklub, Schleswig, 5.8.1929, Abt. 301 Akten des Ober-Präsidiums der Provinz Schleswig-Holstein betreffend die KPD, 4530 (1928-1929), LAS. 
Holger Weiss - 9789004463288

Downloaded from Brill.com@4/26/2023 03: 03:59PM via free access 